Marina Zanotello

\title{
O PRINCÍPIO DA COCULPABILIDADE NO ESTADO DEMOCRÁTICO DE DIREITO
}

\author{
Dissertação de Mestrado
}

Professora Orientadora: Mariângela Gama de Magalhães Gomes

Faculdade de Direito da Universidade de São Paulo

São Paulo 
Marina Zanotello

\title{
O PRINCÍPIO DA COCULPABILIDADE NO ESTADO DEMOCRÁTICO DE DIREITO
}

\begin{abstract}
Dissertação de Mestrado apresentada ao Departamento de Direito Penal, Medicina Forense e Criminologia da Faculdade de Direito da Universidade de São Paulo, como requisito parcial para a obtenção do título de Mestre em Direito, sob a orientação da Professora Mariângela Gama de Magalhães Gomes.
\end{abstract}

Faculdade de Direito da Universidade de São Paulo

São Paulo 
Marina Zanotello

\title{
O PRINCÍPIO DA COCULPABILIDADE NO ESTADO DEMOCRÁTICO DE DIREITO
}

\author{
Dissertação de Mestrado apresentada ao \\ Departamento de Direito Penal, Medicina \\ Forense e Criminologia da Faculdade de \\ Direito da Universidade de São Paulo, \\ como requisito parcial para a obtenção do \\ título de Mestre em Direito, sob a \\ orientação da Professora Mariângela Gama \\ de Magalhães Gomes.
}

São Paulo, de de 2013.

Banca Examinadora

Prof::

Prof.:

Prof.:

Faculdade de Direito da Universidade de São Paulo

São Paulo 
Dedico primeiramente a Deus, a quem entreguei minha vida para que fosse feita Sua vontade, e que abençoou a realização deste trabalho; aos meus pais, Milton (exemplo de honestidade e determinação) $e$ Matilde (modelo de fé, amor e dedicação), aos meus irmãos Marcelo e Mariana, que sempre me incentivaram estudar; aos amigos que estiveram ao meu lado compartilhando as dificuldades da caminhada, a alegria da qualificação e me ensinando que por mais diferentes que sejamos o que realmente importa é o que nos une; e, em especial, a uma pessoa maravilhosa que chegou há pouco tempo em minha vida, mas tempo suficiente para me mostrar que não há o que esteja bom o suficiente que não possa ficar ainda melhor. 
Agradeço primeiramente a Deus por tantas bênçãos que me proporcionou no decorrer deste caminho; ao professor João Paulo que desde a graduação me incentiva a dar sequencia ao estudo do Direito Penal; à minha orientadora, professora Mariângela, que depositou sua confiança no projeto e com seu empenho, com sua disponibilidade, dedicação e paciência fez-se verdadeiro exemplo de pesquisadora a ser seguido. 


\section{RESUMO}

Sob a égide de um Direito Penal garantista, calcado, sobretudo, no respeito aos princípios constitucionais, e com o fim de coadunar o mal da pena com o cerne de todo o sistema que é a máxima da dignidade da pessoa humana, novos temas emergem da realidade social, provocando reflexões no sentido de se atualizar o Direito e seus institutos com as necessidades de uma sociedade que está cada vez mais dinâmica em suas relações.

Devido à amplitude e importância de seu conceito, a culpabilidade vem sendo objeto de estudo, afinal, de acordo com a sistemática adotada pelo Código Penal brasileiro, este instituto corresponde ao cerne da Teoria do Delito.

A partir dos estudos sobre a culpabilidade, surge a teoria da coculpabilidade que, por sua abrangência conceitual, hoje se considera princípio de origem constitucional.

A reflexão parte da gritante desigualdade socioeconômica que se vislumbra atualmente dentro do grupo social, a qual se reforça pela omissão do Estado na efetivação das políticas públicas que possibilitam o acesso dos cidadãos aos direitos sociais, e do fato incontroverso que o meio no qual a pessoa vive condiciona a formação de sua personalidade e, consequentemente, a eleição de seus comportamentos. Atrela-se a isso o caráter seletivo que o sistema penal assume quando se verifica na realidade fenomênica sua utilização equivocada como mecanismo corretor de problemas como a incapacidade estatal de cumprir os deveres constitucionais no que atine à concreção do bem comum.

A coculpabilidade, então, coloca o Estado e a sociedade para dividirem a culpabilidade pelo crime com a pessoa do delinquente, uma vez que se constate no caso concreto que esta foi privada do acesso aos seus direitos fundamentais por negligência estatal; essa divisão de responsabilidade pelo delito se dá na limitação do direito de punir.

O reconhecimento do princípio da coculpabilidade como vigente no Estado Democrático de Direito apresenta-se um tanto controverso ainda na jurisprudência e na doutrina penal brasileira. Tem por objeto a presente pesquisa analisar o alcance de referido princípio e sua aptidão de atenuar ou mesmo excluir a pena, situando-o na Teoria do Delito como mecanismo eficaz para a concreção do Direito Penal mínimo.

Palavras chave: culpabilidade, coculpabilidade, culpabilidade por vulnerabilidade, seletividade do sistema penal, limitação do direito punir. 


\section{SUMMARY}

Under the aegis of a criminal garantista law, trampled, especially in respect to constitutional principles, and consistent with the end of the of the penalty with the evil core of the whole system which is the maximum of human dignity, new themes emerge from the social reality, causing reflections in order to update the law and its institutions to the needs of a society that is increasingly dynamic in their relationship.

Due to the breadth and importance of its concept, culpability has been the object of study, after all, according to the system adopted by the Brazilian Penal Code; this corresponds to the core Theory of Crime institute.

Based on the studies on the guilt arises the co culpability theory which in conceptual comprehensiveness, today it is considered a constitutional principle of origin.

The reflection part of whopping socioeconomic inequality that can be seen today within the social group, which is reinforced by the omission of the state in the fulfillment of public policies that enable citizens' access to social rights, and the incontrovertible fact that the way in which a person lives affects the formation of his personality and therefore the election of their behaviors. It attaches itself to the selective character the penal system assumes that when there is in fact phenomenalistic use as mistaken a mechanism broker problems such as the inability to meet the state constitutional duties concerning the concretion of the common good.

The co culpability then puts the state and society sharing culpability by crime with the person of the delinquent, since it is found in this case was deprived of access to their fundamental rights by state neglect, this division of responsibility for the crime occurs on limiting the right of punishing.

The recognition of the principle of co culpability as existing in a democratic state has become somewhat controversial even in Brazilian criminal jurisprudence and doctrine. Aims at the present research to analyze the scope of this principle and its capacity to mitigate or even delete the sentence, placing it on the Theory of Crime as an effective mechanism for the concretion of minimal Criminal Law.

Keywords: guilt, co culpability, culpability for vulnerability, selectivity of the penal system, limiting the right to punish. 


\section{SUMÁRIO}

Introdução 09

1 - Relação entre Direito Penal e Constituição Federal no Estado Democrático de Direito

1.1 - Dever constitucional do Estado 12

1.2 - Limitações do Direito Penal pela Constituição Federal ............................... 18

1.3 - Princípios Constitucionais Penais ............................................................. 21

1.3.1 - Princípio da Dignidade Humana ..................................................... 22

1.3.2 - Princípio da Igualdade ................................................................... 24

1.3.3 - Princípio da Legalidade ................................................................ 27

1.3.4 - Princípio da Proporcionalidade .................................................... 30

1.3.5 - Princípio da Intervenção Mínima .................................................... 32

1.3.6 - Princípio da Adequação Social ..................................................... 35

1.3.7 - Princípio da Culpabilidade ............................................................ 37

1.3.7.1 - A culpabilidade fundamento da pena ................................. 40

1.3.7.2 - A culpabilidade como elemento do crime ........................... 43

1.3.7.3 - A culpabilidade como limite da aplicação da pena.............. 48

1.3.7.4 - Elementos da Culpabilidade ............................................. 52

1.3.7.5 - Culpabilidade funcional: conceito e críticas ....................... 56

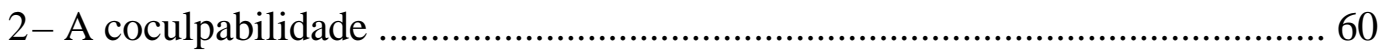

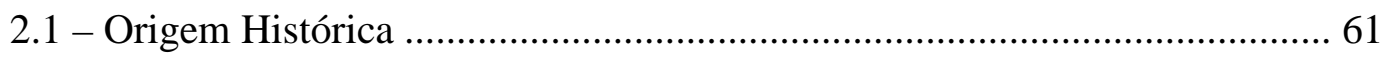

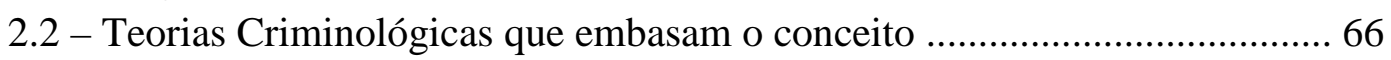

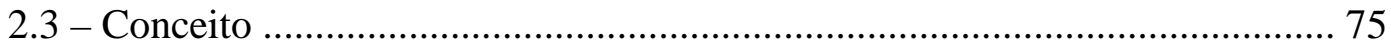

2.4 - Bases constitucionais do princípio da coculpabilidade ............................. 80

2.5 - Localização do princípio da coculpabilidade no Direito Penal ................... 85

2.6 - O Princípio da coculpabilidade no Direito Comparado ............................. 92

3- A coculpabilidade no ordenamento jurídico brasileiro

3.1 - Onde já aparece ..................................................................................... 99

3.2 - Hipóteses possíveis de positivação ....................................................... 101

3.2.1 - A coculpabilidade como circunstância judicial ........................ 103

3.2.2 - A coculpabilidade como circunstância atenuante genérica........ 105

3.2.3 - A coculpabilidade como causa de diminuição da pena ............. 112

3.2.4 - A coculpabilidade como causa supralegal de exculpação ......... 114

3.3 - Alguns acórdãos contrários ao princípio da coculpabilidade..................... 123

3.4 - A culpabilidade por vulnerabilidade ................................................... 130

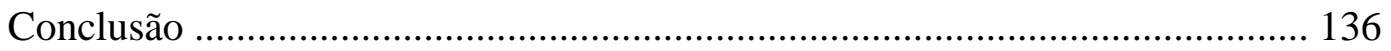

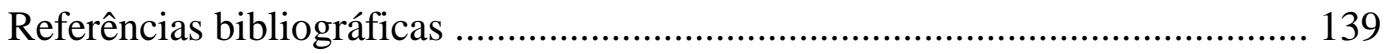




\section{INTRODUÇÃO}

Dizer que o Brasil se constitui em Estado Democrático de Direito implica reconhecer o conteúdo transformador da realidade que este conceito abarca e, sustentando esta máxima, vislumbra-se que a Constituição Federal impôs mais do que a positivação de direitos, a sua efetivação, quando reconheceu os direitos humanos em todas as suas dimensões como sendo direitos fundamentais para as pessoas.

Apresenta-se o Direito como mecanismo de controle social que viabiliza a vida gregária, revelando-se o Direito Penal como ultima ratio, por ser o mais extremo, que apresenta as sanções mais gravosas, as quais afetam de maneira mais incisiva a esfera de direitos individuais do cidadão.

Ao Direito se confere também a missão de promover a igualdade entre os membros do grupo e de tutelar seus interesses; entretanto, estes se mostram, muitas vezes, opostos, porque a sociedade, por sua própria natureza, encontra-se dividida estruturalmente em classes distintas.

Com o fim de estruturar e garantir a ordem social, o Direito Penal acaba sendo moldado às necessidades do Estado, para que, através deste mecanismo de controle social coercitivo, sustente-se a ideologia que interessa aos representantes do povo detentores do poder.

Entretanto, como os representantes do povo, que detém o poder, pertencem às classes mais favorecidas, os fins almejados pelo Direito acabam correspondendo, em grande parte, aos objetivos destas camadas populacionais em detrimento de outras menos favorecidas.

Assim sendo, evidencia-se que o Estado não assegura a todo seu povo os direitos sociais fundamentais elencados na Constituição Federal e acaba contribuindo para o aumento da criminalidade ao passo que vários membros da sociedade restam marginalizados do grupo e da efetivação dos direitos que deveriam receber como pessoas humanas.

Consequentemente, o sistema penal que, teoricamente, deveria atingir de forma equânime as pessoas, de acordo com as práticas de condutas delituosas, intervindo estritamente quando necessário, revela-se corolário da seletividade e da estigmatização, uma vez que a intervenção do ramo mais coercitivo do direito se consubstancia em relação a determinados indivíduos que integram grupos bem definidos na sociedade, o que não somente fomenta a penalização como forma de controle social, mas acaba por promover ainda a degradação da imagem do ser humano que é afetado pela incidência da sanção penal. 
Atentando-se à realidade legislativa brasileira, vislumbra-se que a omissão do Estado aparece inicialmente no plano de formação das leis, no que tange a aspectos do fato social e da coletividade; em relação ao Direito Penal não é diferente, principalmente quando o reconhecimento de determinado instituto jurídico vai de encontro aos objetivos da classe detentora do poder.

Resta, então, ao Poder Judiciário atuar no vácuo da timidez do Poder Legislativo, aplicando as leis de que dispõe baseado em dispositivos normativos muitas vezes ultrapassados e que limitam a exegese, ao passo que as relações sociais se modernizam e ficam cada vez mais dinâmicas.

No âmbito do Direito Penal discute-se acerca das influências que as situações de desigualdades sociais operam em relação ao agente de um delito quando este foi excluído pelo Poder Público do acesso às políticas públicas e se estas circunstâncias devem ser analisadas no momento da fixação da pena em caso de ele vir a sofrer uma condenação.

Partindo-se da noção tripartida, o delito é fato típico, antijurídico e culpável, tendo-se por culpabilidade o juízo de reprovação que recai sobre a conduta criminosa; analisando-se os elementos que constituem o conceito de culpabilidade, depreende-se que a sociedade em da qual o criminoso faz parte, ainda que esteja situado às margens dela, pode influenciar suas ações; é o que se chama de variáveis, que condicionam o comportamento social do acusado e que derivam da carência material de direitos fundamentais.

Timidamente se apresentou a ideia da coculpabilidade que atribui uma parcela de responsabilidade ao Estado pelo cometimento de determinados delitos, principalmente em relação aos de cunho patrimonial, por não ter cumprido com as obrigações que a Magna Carta brasileira lhe outorgou e, assim, ter deixado parte de sua população marginalizada na sociedade.

Sua incidência depende de se verificar a relação entre a conduta criminosa e o contexto social em que o agente viveu, ou seja, se o meio e suas influências repercutiram na formação e condicionamento da personalidade daquela pessoa; em caso positivo, parcela da responsabilidade será atribuída ao Estado omisso e à sociedade excludente, como maneira de minimizar os efeitos da precedente exclusão.

A análise da coculpabilidade parte do prisma sociológico, atendo-se às consequências que o não cumprimento das obrigações constitucionais pelo Estado e pela sociedade desencadeia em relação a alguns determinados grupos de pessoas; a partir dai, questiona-se se seria constitucional a admissibilidade do instituto e, em caso positivo, se configuraria uma resposta jurídica satisfatória aos abusos da marginalidade oriunda do 
descaso estatal, e ainda como seria possível conferir validade e eficácia a este instituto independente de manifestação legislativa.

Partindo desta análise, propôs-se a reestruturação da teoria do delito no que tange ao conteúdo da culpabilidade por se considerar a vulnerabilidade do agente como quesito de grande importância para o cenário delituoso e para a determinação da pena.

Em um sistema estratificado, há de se buscar coerência entre a resposta penal do Estado e os meios que ele dispõe para que todos os indivíduos da sociedade atinjam os objetivos de desenvolvimento humano, econômico, cultural e social.

Não há como analisar a coculpabilidade ou a culpabilidade por vulnerabilidade sem enfrentar o problema da marginalização e da exclusão que ainda se vislumbra dentro do sistema penal, pois é justamente como forma de minorar a reprovação penal pelo reconhecimento da corresponsabilização do Estado por uma atuação negligente que este instituto aparece no mundo jurídico. 


\section{RELAÇÃO ENTRE DIREITO PENAL E CONSTITUIÇÃO FEDERAL NO ESTADO DEMOCRÁTICO DE DIREITO}

\section{1 - Dever constitucional do Estado}

Dispõe a Constituição Federal em seu artigo $1^{\circ}$ que a República Federativa do Brasil se constitui em Estado Democrático de Direito ${ }^{1}$.

Para que um Estado realize a premissa da Democracia, que implica conferir aos governados, todos estes livres e iguais entre si, o poder de decidir sobre as diretrizes políticas do próprio Estado, é necessário que o foco do governo seja a preponderância dos valores fundamentais do povo, devendo se adaptar às circunstâncias de cada época ${ }^{2}$.

A democracia que o Estado Democrático de Direito realiza configura-se um processo de convivência social em que o poder emana do povo e deve ser exercido em proveito do povo, promovendo assim a liberação da pessoa humana de qualquer forma de opressão ${ }^{3}$.

Como a lei emana da vontade do povo, o Estado Democrático de Direito tem por base as normas constitucionais e a elas se subordina, o que caracteriza o princípio da legalidade como um de seus mandamentos, conforme se analisará no decorrer deste capítulo.

A democracia se baseia em três elementos, quais sejam a liberdade, a igualdade e a dignidade. É pela liberdade que a democracia aparece como garantidora da plenitude individual, opondo-se a toda e qualquer ideia de submissão. Pela igualdade, significa que a democracia não se resume apenas nas declarações de direitos, mas na sua efetivação, uma vez que a principal causa de desigualdade é o fator econômico. Os conceitos de liberdade e

\footnotetext{
${ }^{1}$ Artigo $1^{\circ}$ da Constituição da República Federativa do Brasil, 1988 - A República Federativa do Brasil, formada pela união indissolúvel dos Estados e Municípios e do Distrito Federal, constitui-se em Estado Democrático de Direito e tem como fundamentos:

I - a soberania;

II - a cidadania;

III- a dignidade da pessoa humana;

IV - os valores sociais do trabalho e da livre iniciativa;

V - o pluralismo político.

Parágrafo único. Todo o poder emana do povo, que o exerce por meio de representantes eleitos ou diretamente, nos termos desta Constituição.

${ }^{2}$ DALLARI, Dalmo de Abreu. Elementos de Teoria Geral do Estado. 22.ed.atual. São Paulo: Saraiva, 2001, p. 304.

${ }^{3}$ SILVA, José Afonso da. Curso de Direito Constitucional Positivo. 22.ed.rev.atual. São Paulo: Malheiros Editores, 2003, p. 119 e 120.
} 
de igualdade acabam por limitar-se reciprocamente, procurando sempre o equilíbrio entre o individualismo, oriundo da liberdade, e o socialismo, surgido da igualdade ${ }^{4}$.

A dignidade, elemento que se incorporou mais recentemente ao conceito de democracia, é o que, ao lado dos outros dois elementos (liberdade e igualdade) norteiam ao objetivo principal da democracia, que é o bem-estar do ser humano, ou seja, para que se possa assegurar a dignidade é preciso a presença de três fundamentos: o reconhecimento de valores personalíssimos, inerentes a toda pessoa, que não podem ser relativizados; o respeito a liberdade espiritual e a participação efetiva e ativa dos indivíduos na formação da vontade política ${ }^{5}$.

Desta feita, o regime democrático se baseia na liberdade, na igualdade e na dignidade, o que viabiliza uma ampla participação das pessoas nos processos de escolha dos governantes e sua transparência; isso assegura os direitos individuais e preconiza a realização do bem comum.

José Joaquim Gomes Canotilho considera o Estado Democrático de Direito, como forma de racionalização e generalização do poder político das sociedades modernas, no qual a política é o campo das decisões obrigatórias e tem como objetivo o estabelecimento e a conservação da ordem, da paz, segurança e justiça na comunidade, ou seja, trata-se o Estado Democrático de Direito de um Estado limitado pelo direito em que o poder político estatal é legitimado pelo povo ${ }^{6}$.

Acerca do conceito de Estado Democrático de Direito é possível então identificar três elementos que o constituem, quais sejam, leis que representam a vontade da maioria, respeitando as liberdades fundamentais; o indivíduo como foco do Estado por meio das disposições constitucionais e a execução das leis por juízes cujo poder é independente, consoante o princípio da separação dos poderes ${ }^{7}$.

Disso se depreende que a tarefa fundamental do Estado Democrático de Direito consiste em superar as desigualdades sociais e regionais e instaurar um regime democrático que realize a justiça social.

\footnotetext{
${ }^{4}$ SOUZA, Daniel Coelho de. Interpretação e democracia. 2ed. São Paulo: Editora Revista dos Tribunais, 1979 , p. 143-147.

${ }^{5}$ Idem.

${ }^{6}$ CANOTILHO, José Joaquim Gomes. Direito Constitucional e Teoria da Constituição. 6 ed. Coimbra/Portugal: Livraria Almedina, 2002, p. 231.

${ }^{7}$ Artigo $2^{\circ}$ da Constituição da República Federativa do Brasil - São Poderes da União, independentes e harmônicos entre si, o Legislativo, o Executivo e o Judiciário.
} 
Calcado nas premissas constitucionais, o Estado Democrático de Direito deve ater-se

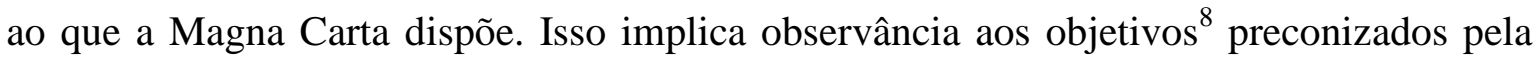
Lei Maior, bem como aos deveres por ela impostos.

Ignácio Berdugo Gómez de la Torre ${ }^{9}$ expõe que a Constituição traz princípios gerais que vinculam os legisladores, os juízes e os membros do Poder Executivo e é a partir desses princípios que se deve interpretar e aplicar todas as leis.

Os princípios constitucionais conduzem ao alcance dos objetivos traçados no artigo $3^{\circ}$, que nitidamente tratam o cidadão como prioridade, a Constituição Federal estipula as garantias fundamentais dos indivíduos no artigo $5^{\circ}$ e os direitos sociais no artigo $6^{\circ}$.

Luigi Ferrajoli ${ }^{10}$ sustenta que os direitos fundamentais se revestem dos caracteres da indisponibilidade e da inviolabilidade por serem de natureza personalíssima e corresponde a forma jurídica positivada dos direitos naturais, que tem como garantia o fundamento político ou externo do moderno Estado de Direito, o que possibilita que as disposições contrárias aos direitos fundamentais sejam anuladas.

Consagram-se os direitos sociais ${ }^{11}$ na chamada Segunda Geração dos Direitos Humanos, momento em que o Estado passa intervir na ordem econômica e social, com escopo de se aproximar do indivíduo.

As primeiras legislações que fizeram menção aos direitos sociais datam do início do século XX e correspondem às Constituições do México em 1917 e de Weimar em 1919, as quais traziam a premissa da igualdade material entre os indivíduos e obrigavam que os Estados não apenas respeitassem, mas também concretizassem os direitos sociais, econômicos e culturais ${ }^{12}$.

Como já mencionado, esses direitos originaram-se a partir das situações de abuso que se delineavam nas relações privadas e do poder econômico, época em que vidas humanas eram perdidas ante a falta de condições adequadas de trabalho nas indústrias e da escassez

\footnotetext{
${ }^{8}$ Artigo $3^{\circ}$ da Constituição da República Federativa do Brasil - Constituem objetivos fundamentais da República Federativa do Brasil:

I- construir uma sociedade livre, justa e solidária;

II- garantir o desenvolvimento nacional;

III- erradicar a pobreza e a marginalização e reduzir as desigualdades sociais e regionais;

IV- promover o bem de todos, sem preconceitos de origem, raça, sexo, cor, idade e quaisquer outras formas de discriminação.

${ }^{9}$ TORRE, Ignácio Berdugo Gómez de la. Lecciones de derecho penal. Parte general. 2.ed. Editorial: WK Educación, 1999, p. 40.

${ }^{10}$ FERRAJOLI, Luigi. Derecho y razión: teoría del garantismo penal. Editorial Trotta, 1995, p. 356.

${ }^{11}$ Artigo $6^{\circ}$ da Constituição da República Federativa do Brasil - São direitos sociais a educação, a saúde, a alimentação, o trabalho, a moradia, o lazer, a segurança, a previdência social, a proteção à maternidade e à infância, a assistência aos desamparados, na forma desta Constituição.

${ }^{12}$ PAULO, Vicente; ALEXANDRINO, Marcelo. Direitos fundamentais. Rio de janeiro: Impetus, 2003, p.12.
} 
de recursos básicos nos países europeus do século XIX. Os diretos à educação, à saúde, ao trabalho, à moradia, ao lazer, à segurança, à previdência social, à proteção à maternidade e à infância foram motivados sob o contexto da Revolução Industrial ${ }^{13}$.

Além do que, durante o processo de industrialização, evidenciou-se significativa diferença entre as classes sociais; em uma posição hierarquicamente superior estavam os detentores do capital que buscavam obter o máximo de lucros pela exploração do proletariado e, na parte inferior, encontrava-se o trabalhador que, não tendo acesso aos meios de produção, dispunha unicamente de sua força de trabalho e, devido à baixa remuneração recebida pela hora trabalhada, tampouco tinham acesso aos bens de consumo $^{14}$.

Devido à expansão do setor industrial, manifestou-se também a necessidade de se ampliar os serviços públicos, de forma que abrangessem as diversas áreas sociais; assim, sob o discurso de regulamentar as atividades produtivas, de assegurar a geração de riquezas materiais e com isso diminuir as desigualdades sociais, o Estado passou a intervir na economia.

Contudo, o Estado intervencionista do bem-estar social tornou-se mais uma forma de se utilizar o poder para defender os interesses que circundam o capital, ainda que para isso se tivesse que deixar os interesses sociais em segundo plano ${ }^{15}$.

Isto porque as indústrias continuavam apresentando condições subumanas de trabalho, ainda após as várias reivindicações proletárias, diversos direitos sociais tenham sido reconhecidos e, por consequência, incorporados nos textos constitucionais, ou seja, tinha-se o direito assegurado nas leis, mas, na prática, o Estado não investia o suficiente para resolver efetivamente o problema.

Assim sendo, para a parcela da população socialmente excluída, esses direitos sociais que, apesar de positivados, não chegaram a ser concretizados pelo Estado, tornam-se algo ideológico, abstrato, distante de sua realidade, o que obsta que essas pessoas ocupantes da classe inferiorizada tenham oportunidade de acessar melhores condições de vida e, simultaneamente, condena-as eternamente à miséria, já que são marginalizadas do grupo social.

\footnotetext{
${ }^{13}$ Idem, p. 13.

${ }^{14}$ BARROS, Sérgio Resende de. Direitos humanos: paradoxo da civilização. Belo Horizonte: Del Rey, 2003, p. 426.

${ }^{15}$ GUIMARÃES, Claudio Alberto Gabriel. Funções da pena privativa de liberdade no sistema penal capitalista. Rio de Janeiro: Revan, 2007, p. 214.
} 
Richard Quinney explica que o Estado reflete e serve às necessidades da classe dominante por meio do seu sistema de leis, pois é através do ordenamento jurídico que se estabelece quem são os detentores do poder e, consequentemente, quem são os dominados $^{16}$. O próprio sistema obstaculiza que ocupantes das classes baixas ascendam à classe burguesa.

Isso porque os valores vigentes em uma determinada sociedade são escolhidos por uma classe dominante de pessoas, as quais fazem do direito e do próprio sistema penal o retrato de uma ideologia política e sociológica voltada a atender os interesses dessas mesmas classes privilegiadas ${ }^{17}$.

Para os autores George Rusche e Otto Kirchheimer, a antiga diferenciação entre as classes foi mantida pela legislação criminal, principalmente no tocante à aplicação da pena; dessa forma, falar de igualdade perante a lei não impedia de se conferir interpretações diversas para os mesmos fatos quando estes tivessem sido cometidos por ocupantes de classes sociais diferentes ${ }^{18}$.

Nesse sentido, pode-se entender que por meio do cometimento de crime as pessoas ocupantes das classes menos favorecidas buscam se aproximar socialmente das classes superiores e estas, por sua vez, acabam se valendo do direito criminal para coibir tais práticas, coagindo a maior parte da população de uma determinada sociedade, ao mesmo tempo em que reafirma para si o poder de governar ${ }^{19}$.

Os direitos humanos se caracterizam pela aptidão de se opor ao governo para limitar sua atuação ou exigi-la conforme haja necessidade, ou ainda de defender ou de promover o indivíduo na comunidade onde este vive e onde também o poder do Estado incide.

Lenio Streck $^{20}$ assevera que as garantias, tanto sociais quanto liberais, expressam os direitos fundamentais do cidadão frente aos poderes do Estado e tutelam a questão da marginalização que atinge as minorias e as separa da maioria da sociedade integrada.

Emergem, então, os direitos sociais sob a égide de um Estado intervencionista visando resguardar a parcela mais frágil da sociedade, em uma tentativa de equilibrar a situação de extrema diferença que se delineava entre as classes sociais.

\footnotetext{
${ }^{16}$ QUINNEY, Richard. O controle do crime na sociedade capitalista: uma filosofia crítica da ordem legal. Criminologia crítica. Rio de Janeiro: Graal, 1980, p. 237.

${ }^{17}$ RUSCHE, George; KIRCHHEIMER, Otto. Punição e estrutura social. 2.ed. Rio de Janeiro: Revan, 2004, p. $142-143$.

${ }^{18}$ RUSCHE, George; KIRCHHEIMER, Otto. Op.cit., p. 143.

${ }^{19}$ QUINNEY, Richard. Op.cit., p. 237.

${ }^{20}$ STRECK, Lenio. O trabalho dos juristas na perspectiva do Estado Democrático de Direito: da utilidade de uma crítica garantista. Rio de Janeiro, 1996, p. 44.
} 
Acerca do conteúdo dos direitos sociais, George Marmelstein ${ }^{21}$ afirma que são estes que impõem as diretrizes e estabelecem as tarefas que incumbem ao Estado a fim de que este viabilize aos indivíduos as condições necessárias para seu desenvolvimento humano e com dignidade.

Nítido se faz que as normas que definem os direitos sociais preconizam a realização da igualdade material (esta será mais bem explicada quando se analisar o princípio constitucional da igualdade, ainda neste capítulo), pois a consideram condição essencial para o exercício pleno dos outros direitos ${ }^{22}$.

Segundo Ingo Sarlet ${ }^{23}$, o diferencial dos direitos sociais corresponde a sua dimensão positiva, uma vez que se cuida de propiciar um "direito de participar do bem-estar social $^{24,}$, ou seja, de se lograr a liberdade por intermédio do Estado.

Há de observar que, ao positivar os direitos humanos na Constituição, o legislador constituinte originário considerou os direitos sociais como direitos fundamentais, tendo os inserido, em sua maioria, dentro do título II que é reservado aos direitos e garantias fundamentais.

George Marmelstein esclarece ainda que, à luz do direito positivo-constitucional brasileiro, os direitos sociais são verdadeiros direitos fundamentais, não apenas por estarem previstos na Constituição e corresponderem à norma constitucional, mas também em sentido material, já que são valores intimamente ligados ao princípio da dignidade da pessoa humana ${ }^{25}$.

O legislador Constituinte preconizou tanto os direitos sociais e seu caráter fundamental, no que tange ao desenvolvimento humano e social do cidadão, que os conferiu aplicação imediata, no artigo $5^{\circ} \S 1^{\circ}$ da Magna Carta, bem como os instituiu em cláusula pétrea, no artigo $60, \S 4^{\circ}$, inciso IV do texto constitucional.

Acerca disso, elucida Ana Cristina Costa Meireles ${ }^{26}$ as normas de direitos sociais fundamentais possuem aplicação direta e imediata na forma preconizada pelo $\S 1^{\circ}$ do art. $5^{\circ}$ da Constituição Federal, gerando diversas posições jurídicas para os administrados.

\footnotetext{
${ }^{21}$ MARMELSTEIN, George. Curso de direitos fundamentais. São Paulo: Atlas, 2008, p. 51.

22 BONAVIDES, Paulo. Curso de direito constitucional. 21. ed. São Paulo: Malheiros, 2007, p. 564.

${ }^{23}$ SARLET, Ingo Wolfgang. A eficácia dos direitos fundamentais. 6. ed. Porto Alegre: Livraria dos Advogados, 2006, p. 56 e 57.

${ }^{24}$ LAFER Apud SARLET, Ingo Wolfgang. Op.cit., p. 57.

${ }^{25}$ MARMELSTEIN, George. Op.cit., p. 174.

${ }^{26}$ MEIRELES, Ana Cristina Costa. A eficácia dos direitos sociais. Salvador: JusPodivm, 2008, p. 236.
} 
Diante disso, entende-se que os direitos fundamentais sociais correspondem a uma imposição constitucional ao Poder Público e a vinculação deste àqueles é necessidade premente a fim de se viabilizar as transformações sociais e econômicas.

Vislumbra-se, então, seu cunho prestacional, ou seja, ao prever esses direitos, a Constituição obriga o Estado à prestação de serviços, que são considerados serviços públicos essenciais, e que devem ser devidamente atendidos.

Nesse sentido é a lição de Victor Abramovich e Christian Courtis ${ }^{27}$, quando mencionam em sua obra que as obrigações prestacionais do Estado se constituem nas seguintes: obrigação de adotar medidas imediatas, ou seja, o Estado deve implantar atos concretos, deliberados e orientados em um prazo razoavelmente breve, prestando justificativas se eventualmente não lograr a consecução do objetivo. São exemplos dessas obrigações imediatas do Estado: obrigação de adequação do marco legal; obrigação de vigilância efetiva, informação e formulação de plano; obrigação de provisão de recursos efetivos; também tem obrigação de garantir níveis essenciais dos direitos, ou seja, o Estado deve demonstrar todo o esforço realizado para utilizar com prioridade a totalidade dos recursos de que dispõe; a obrigação de progressividade e proibição de retrocesso, que implica a satisfação plena dos direitos que devem assistir à população, um progresso gradativo nas melhorias de condições para o exercício dos direitos sociais.

\section{2 - Limitações do Direito Penal pela Constituição Federal}

A influência do movimento iluminista do século XVIII atingiu sensivelmente o Direito Penal, principalmente com a ideia de pacto social, o que ensejou o desencadeamento de um processo de limitação do poder punitivo do Estado pela reserva legal e pelo foco concedido aos direitos e às garantias da pessoa humana. Foi vedado ao Estado criminalizar a esfera do pensamento, sendo possível sancionar apenas as condutas danosas previamente acordadas para não incorrer em excesso ou desvio ${ }^{28}$.

A interferência do Estado ficou limitada ao âmbito do indispensável e direcionada somente para dirimir os conflitos sociais que atinjam os bens jurídicos penalmente tutelados. Partindo do princípio da legalidade estabeleceu-se um modelo de direito penal mínimo que condicionou a imputação penal a uma série de condições e princípios calcados na proteção dos direitos fundamentais da pessoa humana e que, como exposto

${ }^{27}$ ABRAMOVICH, Victor; COURTIS, Christian. Los derechos sociales como derechos exigibles. $2^{\mathrm{a}}$ ed. Madrid: Editorial Trotta, 2004, p. 79-116.

${ }^{28}$ CARVALHO, Amilton Bueno de; CARVALHO, Salo de. Aplicação da pena e garantismo. 4. ed. Rio de Janeiro: Lumen Juris, 2008, p. 10. 
anteriormente, se fazem verdadeiras premissas nos Estados Democráticos de Direito, estabelecendo, assim, os vínculos formais e materiais de validade jurídica das normas penais e processuais penais, que antes não se faziam presentes nos procedimentos autoritários $^{29}$; isto significa que os atos do poder estatal passam a ter a legitimidade conferida pela sua compatibilidade pela sua vinculação formal e material com a Lei Maior.

No Estado de Direito, qualquer ação venha a ser utilizada com o escopo de cercear direitos deve atender à estrita autorização legal, preenchendo os requisitos da legitimidade e adequação. Segundo Alessandro Baratta $^{30}$, o direito que fundamenta o poder de punir sobre a base de regras é o mesmo direito que fundamenta, em virtude de decisões, as regras fundadoras do direito de punir, como um processo complexo de referência própria.

Alessandro Baratta ressalta a impossibilidade de legitimação calcada puramente na racionalidade do direito, ante a necessidade de um alcance que transcenda o limite negativo imposto pelo normativismo, o que enseja a ideia de funções socialmente úteis ao sistema penal fundadas nas teorias relativas ou utilitárias da pena ${ }^{31}$.

Ao examinar a questão do poder de punir do Estado, Massimo Pavarini ${ }^{32}$ elucida que a defesa social corresponde a uma ideologia que, por vezes, se revela sedutora por se apresentar capaz de atribuir necessidade, legitimidade e até mesmo um caráter científico ao sistema repressivo vigente, ou seja, reivindica o mérito de haver conduzido a política criminal a uma prática científica por meio da qual a sociedade se defende do crime.

Assim o poder de punir do Estado busca sua legitimação através do discurso de proteção aos bens jurídicos, de reeducação do delinquente, de prevenção de novos delitos e se elege o Direito Penal como meio para tanto.

A lição de Juarez Cirino dos $\operatorname{Santos}^{33}$ é clara no sentido de que o sistema penal surge como garantidor de uma ordem social justa, tendo por fim proteger bens jurídicos e promover o bem comum. Essa concepção é legitimada precipuamente pela teoria da pena, que se estrutura na dupla finalidade de retribuição e de prevenção (geral e especial) do crime.

Da obra em que Luigi Ferrajoli apresenta o garantismo penal depreende-se que o sistema garantista proposto pelo autor tem por escopo diminuir as incertezas que permeiam

\footnotetext{
${ }^{29}$ Idem., p. 25-26.

${ }^{30}$ BARATTA, Alessandro. Viejas y nuevas estratégias en la legitimación del derecho penal. Poder y Control, Barcelona, 1986, p. 77-92.

${ }^{31}$ Idem.

${ }^{32}$ PAVARINI, Massimo. Control y dominación. Teorias criminológicas burguesas y proyecto hegemónico. Tradução de Ignacio Munagorri. México: Siglo Veintiuno, 1988, p. 49.

${ }^{33}$ SANTOS, Juarez Cirino dos. Direito Penal: a nova parte geral. Rio de Janeiro, Forense, 1985, p. 26.
} 
o processo penal; desde a análise dos fatos até o momento em que se vai atribuir uma pena ao autor de um delito, há de se observar as garantias para que o sistema e o processo penal sejam mais coerentes com a realidade ${ }^{34}$.

De acordo com a tradicional lição de Cesare Bonesana, o marquês de Beccaria ${ }^{35}$, o "jus puniendi" é consequência do contrato social firmado entre os cidadãos, que cedem parte de suas liberdades para constituir um poder soberano que fica como depositário dessas liberdades, reunindo-as e direcionando-as à concreção da harmonia social, sendo nesse sentido que se fundamenta o direito de punir do Estado.

No mesmo sentido destaca-se a visão de Norberto Bobbio ${ }^{36}$, para quem o contrato social tem por objeto a transferência para o Estado de direitos que são inerentes ao homem pelo seu estado de natureza; dessa forma, o homem natural se torna homem civil ou cidadão. O principal direito que o homem transfere ao Estado é o direito de liberdade, uma vez que, pelo contrato social, o Estado torna-se depositário das liberdades individuais.

Assim, o contrato social propiciou a reunião dos indivíduos em sociedade, além de operar também a transferência de direitos das pessoas para o Estado, afinal, o ser humano não estaria ligado ao conjunto de normas reguladoras da sociedade apenas por nobreza de espírito, mas o faz pela necessidade de sobreviver em sociedade e a vida em sociedade exige que cada indivíduo cumpra seu papel social e aqueles que não o cumprem restam colocados às margens do grupo e elencados para fora do convívio.

A importância de tais apontamentos para o presente trabalho se dá porque o direito penal se depara com uma ambivalência, pois, ao mesmo tempo em que protege bens jurídicos indispensáveis, também acaba por restringir a liberdade, que é um direito fundamental individual protegido constitucionalmente e que, pela incidência da sanção penal, o sujeito infrator restará totalmente privado dele ${ }^{37}$.

A argumentação de Michel Foucault ilustra bem esse contexto a partir da suposição de que o cidadão tenha aceitado a lei que poderá puni-lo, assim como aceitou as demais leis da sociedade que lhe conferem direitos; a figura do criminoso revela um ser juridicamente paradoxal, uma vez que rompeu o pacto e, dessa forma, tornou-se inimigo do grupo, mas que também vai participar da punição que se exercerá sobre ele. Isso quer dizer

\footnotetext{
${ }^{34}$ FERRAJOLI. Luigi. Direito e razão: teoria do garantismo penal. Tradução de Ana Paula Zomer et.al. São Paulo: Editora Revista dos Tribunais, 2002, p. 87.

${ }^{35}$ BECCARIA, Cesare Bonesana. Dos delitos e das penas. São Paulo: Editora Martin Claret, 2002, p. 19.

${ }^{36}$ BOBBIO, Norberto. Sociedade e estado na filosofia política moderna. Trad. Carlos Nelson Coutinho. $4^{\mathrm{a}}$ ed. São Paulo: Ed. Brasiliense, 1994, p. 71.

${ }^{37}$ CAMARGO, A. L. Chaves de. Bases do Direito Penal no Estado Democrático de Direito. Revista Impulso da Universidade Metodista de Piracicaba, p. 89.
} 
que qualquer crime, até o menor deles, ataca toda a sociedade e toda essa sociedade, inclusive o criminoso, se fará presente na punição por mais branda que ela seja ${ }^{38}$.

Nesse sentido, a sanção penal exerce uma função generalizada, que se estende a todo o corpo social e a cada um de seus elementos. A partir daí, o Estado se depara com a questão de mensurar e aplicar de forma econômica o poder de punir, isso porque a infração lança o indivíduo contra todo o corpo social, o que, teoricamente, dá à sociedade o direito de se levantar contra ele com o fim de puni-lo; contudo, isso se torna uma luta desigual ao passo que se unem de um só lado todas as forças, todo o poder, todos os direitos. Dessa forma se representa a defesa de cada um, tendo-se o infrator por inimigo comum, um traidor que desfere seus golpes dentro da sociedade. Por isso, o direito de punir deslocou-se da vingança do soberano à defesa da sociedade ${ }^{39}$.

Ante a incidência tão enfática da sanção penal na esfera dos direitos do indivíduo, cumpre analisar, ainda que de forma breve, alguns princípios constitucionais penais que limitam a interferência do Estado no exercício do seu direito de punir, tanto porque o Direito Penal, hoje amparado no garantismo, deve atenção e obediência primordialmente ao princípio constitucional da dignidade da pessoa humana, do qual decorrem outros princípios que norteiam a incidência deste mecanismo de controle social de repercussão tão extremada.

\section{3 - Princípios Constitucionais Penais}

Se, pela força normativa da Constituição e pela supremacia desta, vislumbra-se que as pessoas devem direcionar suas condutas em sociedade para o respeito aos direitos fundamentais de seus semelhantes, então, o Estado, ente de direito publico detentor do "jus puniendi", encarregado de tutelar os direitos, deve mais ainda se esforçar para que seus atos, atos de seus agentes, cumpram os valores preconizados pela Constituição e realizem os direitos fundamentais, no que tange às suas relações com os indivíduos.

O que limita o direito estatal de punir são os princípios constitucionais penais que orientam a atividade legislativa e também judicial.

Acerca da importância dos princípios constitucionais no âmbito do Direito Penal, Renato de Lima Castro ${ }^{40}$ escreveu que, como os princípios penais de garantia funcionam

\footnotetext{
${ }^{38}$ FOUCAULT, Michel. Vigiar e punir: nascimento da prisão. Trad. Raquel Ramalhete. 34 ed. Petrópolis, Vozes. 2007, p. 76

${ }^{39}$ Idem.

${ }^{40}$ CASTRO, Renato de Lima. Garantismo penal: uma ilusão? In: PRADO, Luiz Regis. (Org.). Direito penal contemporâneo: Estudos em homenagem ao Professor José Cerezo Mir. São Paulo: Revista dos
} 
como verdadeiros limites materiais à intervenção legislativa no direito penal, e como o Poder Judiciário é responsável por salvaguardar a Constituição Federal e, consequentemente, os valores por ela trazidos, cabe a este o exercício do controle difuso da constitucionalidade das leis, ou seja, tem ele a aptidão de declarar a eventual inconstitucionalidade dos tipos penais que não se coadunem com os princípios penais estabelecidos na Magna Carta.

Segundo Francesco Palazzo ${ }^{41}$, o ordenamento jurídico-penal somente se legitima sob o aspecto material se estiver de acordo com os princípios constitucionais, sejam estes expressos ou tácitos, mas cuja observância se faz imprescindível para o modelo de Estado Democrático de Direito, pois os princípios constitucionais penais servem como limite à intervenção estatal no âmbito do Direito Penal e também conferem legitimidade à intervenção.

\subsection{1 - Princípio da Dignidade Humana}

A dignidade da pessoa humana é fundamento da República Federativa do Brasil, conforme dispõe o artigo $1^{\circ}$, inciso III da Constituição Federal.

Segundo José Joaquim Gomes Canotilho ${ }^{42}$, o fato de República ter por base a dignidade da pessoa humana significa o reconhecimento do indivíduo como limite e fundamento do domínio político daquele governo, ou seja, tem-se a República como a organização política que serve ao homem. Para tanto, faz-se necessário que se reconheça o ser humano como cidadão pleno de direitos e de garantias que lhe possibilitem a realização dos seus anseios básicos.

Trata-se de um valor supremo, de um princípio que norteia a interpretação e a aplicação de todos os direitos e garantias individuais dos cidadãos previstos na Lei Maior brasileira $^{43}$.

Em um Estado Democrático de Direito a prioridade é a realização do bem estar do ser humano e o respeito por sua dignidade, na busca por um meio social justo e pacífico, conforme consta do preâmbulo da Constituição.

Como assevera Daniel Sarmento ${ }^{44}$, o Estado tem não apenas o dever de se abster de praticar atos que atentem contra a dignidade humana, como também o de promover esta

Tribunais, 2007, p. 136.

${ }^{41}$ PALAZZO, Francesco C. Valores constitucionais e direito penal - um estudo comparado. Trad. Gérson Pereira dos Santos. Porto Alegre: Sérgio Antonio Fabris Editor, 1989, p. 87.

${ }^{42}$ CANOTILHO, José Joaquim Gomes. Op.cit., p. 225.

${ }^{43}$ NUNES, Luiz Antonio Rizzatto. O princípio Constitucional da Dignidade da Pessoa Humana. São Paulo: Saraiva, 2002, p. 46. 
dignidade através de condutas ativas, garantindo o mínimo existencial para cada ser humano em seu território.

Isso significa que a dignidade do ser humano pode ser aviltada não apenas quando o indivíduo se vê privado de alguma das suas liberdades fundamentais, como também quando não tem acesso aos direitos que asseguram a satisfação de suas necessidades básicas como alimentação, educação básica, saúde e moradia.

Acerca do conteúdo deste princípio, Ingo Sarlet ${ }^{45}$ esclarece que a dignidade da pessoa humana é irrenunciável e ela existe independente de o Direito a reconhecer ou não. Para este autor, a ordem jurídica prevê a dignidade humana, promove e a protege, o que, evidentemente, é importante, porque é pela lei que a dignidade humana se efetiva para os seus destinatários, ou seja, que ela deixa o mundo hipotético das normas jurídicas e passa a integrar e ser aplicada no mundo dos fatos, na vida social.

Segundo Norberto Bobbio $^{46}$, as declarações recentes dos direitos do homem compreendem, além dos direitos individuais tradicionais, que consistem em liberdades, também os chamados direitos sociais, que constituem em poderes.

Jorge Miranda ${ }^{47}$ sistematizou características da dignidade da pessoa humana da seguinte maneira: a dignidade da pessoa humana dirige-se, simultaneamente, a todas e cada uma das pessoas, sendo individual e concreta; independe a dignidade de qualquer situação que a pessoa vive dentro da comunidade; o primado da pessoa é o do ser, não o do ter; a liberdade prevalece sobre a propriedade; a proteção da dignidade das pessoas vai além do conceito de cidadania trazido pela Constituição, postulando uma visão universal acerca da atribuição de direitos; a dignidade da pessoa pressupõe autonomia da pessoa, sua autodeterminação em relação ao Estado, às demais entidades públicas, bem como às outras pessoas.

Especificamente para o Direito Penal, a dignidade humana deve estar sempre em foco. De acordo com Luigi Ferrajoli ${ }^{48}$, o valor da pessoa humana impõe uma limitação fundamental em relação à qualidade da pena, pois é sobre este valor que se funda o rechaço da pena de morte, das penas corporais, das penas infames e, por outro lado, da prisão perpetua e das penas privativas de liberdade excessivamente extensas. A crítica do autor

${ }^{44}$ SARMENTO, Daniel. A ponderação de interesses na Constituição. Rio de Janeiro: Lúmen Júris, 2000, p. 71.

${ }^{45}$ SARLET, Ingo Wolfgang. Dignidade e direitos fundamentais na Constituição Federal de 1988. Porto Alegre: Livraria do Advogado, 2001, p. 40.

${ }^{46}$ BOBBIO, Norberto. A era dos direitos. Rio de Janeiro: Editora Campos, 1992, p. 21.

${ }^{47}$ MIRANDA, Jorge. Manual de direito constitucional. Tomo IV. Coimbra: Coimbra, 1991, p. 169.

${ }^{48}$ FERRAJOLI, Luigi. Direito e Razão: Teoria do Garantismo Penal. São Paulo: Editora Revista dos Tribunais, 2002, p. 318. 
concerne que um Estado que mata, tortura, humilha um cidadão contradiz sua razão de ser colocando-se no nível dos mesmos delinquentes.

Conclui-se, então, que apenas as necessidades humanas, explicitadas naquelas situações mais extremas, devem ser tuteladas pelo direito penal.

\subsection{2 - Princípio da Igualdade}

O princípio da igualdade, exposto já no Preâmbulo da Magna Carta brasileira, tem sede explícita no texto constitucional, encontrando-se positivado no "caput" do artigo $5^{\circ}$ da Constituição Federal ${ }^{49}$.

Ainda na Magna Carta brasileira, vislumbra-se que o inciso III do artigo $1^{\circ}$ traz como fundamento da República Federativa do Brasil a dignidade da pessoa humana e o artigo $3^{\circ}$, inciso IV estabelece como sendo um dos objetivos fundamentais da República "promover o bem de todos, sem preconceitos de origem, raça, sexo, cor, idade e quaisquer outras formas de discriminação".

Disso se depreende que o princípio da igualdade consagrado pela Constituição Federal encontra-se vinculado à obrigatoriedade da redução das desigualdades. Por isso, não basta que o Estado proíba a discriminação e se abstenha também de discriminar, mas implica que ele atue de forma ativa para alcançar tais metas, tanto porque a simples vedação de tratamentos discriminatórios não é suficiente para colocar em prática as ações que levam à referida realização dos objetivos fundamentais constitucionalmente garantidos.

Segundo Alexandre de Moraes, este princípio opera em dois planos. De um lado, frente ao legislador ou ao próprio Poder Executivo, no que concerne à edição, de leis e de atos normativos ou medidas provisórias, respectivamente, e, assim, impede tratamentos diferenciados de forma abusiva em relação a pessoas que se encontram em situação similar. Em outro plano, o princípio em análise obriga o intérprete da norma e seu aplicador, ou seja, a autoridade pública, de se utilizar da lei e dos atos normativos sem estabelecer diferenciações em razão de classe social, raça, sexo, religião e convicções filosóficas ou políticas ${ }^{50}$.

\footnotetext{
${ }^{49}$ Artigo $5^{\text {o } ~ " c a p u t ” d a ~ C o n s t i t u i c ̧ a ̃ o ~ F e d e r a l ~ d a ~ R e p u ́ b l i c a ~ F e d e r a t i v a ~ d o ~ B r a s i l ., ~} 1988$ - Todos são iguais perante a lei, sem distinção de qualquer natureza, garantindo-se aos brasileiros e aos estrangeiros residentes no País a inviolabilidade do direito à vida, à liberdade, à igualdade, à segurança e à propriedade, nos termos seguintes.

${ }^{50}$ MORAES, Alexandre de. Direito Constitucional. 12.ed. São Paulo: Atlas, 2002, p. 65.
} 
Tem-se então que o princípio da igualdade assume um caráter de dupla aplicação, qual seja: uma que se encontra na teoria da lei, segundo a qual se coíbe que a lei atribua privilégios injustificados a algumas pessoas; e outra de cunho prático, voltado à realidade, e que tende a minimizar os efeitos decorrentes das desigualdades evidenciadas nas situações da vida cotidiana da sociedade.

De acordo com a lição de Uadi Lammego Bulos ${ }^{51}$ a diretriz da igualdade limita a atividade legislativa, uma vez que não é dado ao legislador criar normas de cunho discriminatório ou que obstem a equiparação entre os cidadãos de forma arbitrária. Também a autoridade pública encontra-se sujeita ao ditame da isonomia, assim como um magistrado que não pode aplicar atos normativos que levem a situações de desigualdade e que, além disso, tem o dever de banir arbitrariedades ao exercer a jurisdição em cada caso concreto, o que se delineia por meio dos atuais mecanismos de uniformização da jurisprudência, vislumbrados tanto na órbita constitucional (recursos extraordinário e ordinário) como no campo infraconstitucional (legislação processual). Por fim, ao particular também é vedado adotar condutas discriminatórias, preconceituosas, racistas ou de maledicências em face de seus semelhantes, podendo vir a ser responsabilizado civil e penalmente, com base na própria Constituição Federal e nas leis em vigor.

Portanto, resta claro que a Constituição Federal impõe ao princípio da igualdade um conceito constitucional dinâmico e positivo e ao Estado e à sociedade uma obrigatoriedade de ação para sua concreção como expressão da própria democracia.

José Afonso da Silva ${ }^{52}$, ao doutrinar sobre o direito constitucional de igualdade que a Magna Carta brasileira estabelece como princípio, escreve que "porque existem desigualdades, é que se aspira à igualdade real ou material que busque realizar a igualização das condições desiguais".

Este mesmo autor considera a igualdade como signo fundamental da democracia e justifica isso com a consideração de que a burguesia nunca postulou um regime de igualdade tal como fez em relação à liberdade, porque um regime de igualdade contrastaria seus interesses ${ }^{53}$.

Neste sentido, Marilena Chaui ${ }^{54}$ tece uma reflexão, considerando a existência de um autoritarismo social que se origina da hierarquia que divide as pessoas dentro da sociedade e através da qual os ocupantes da parte inferior da pirâmide hierárquica são levados a

\footnotetext{
${ }^{51}$ BULOS, Uadi Lammego. Constituição Federal anotada. São Paulo: Saraiva, 2002, p. 77 e 78.

${ }^{52}$ SILVA, José Afonso da. Curso de Direito Constitucional Positivo. São Paulo, 2002, p.212-213.

${ }^{53}$ SILVA, José Afonso da. Op.cit., p. 210.

${ }^{54}$ CHAUI, Marilena. Convite à Filosofia. Editora Ática: São Paulo, 2002, p. 435.
} 
obedecer aos mandamentos que os minoritários ocupantes da parte superior de referida pirâmide estabelecem; por isso, na visão da autora, existe um contrassenso entre o discurso de democracia, esta emanada após um regime autoritário, e o sentido real da incidência do princípio da igualdade no âmbito social, pois considera ela que o que realmente impera no cenário social corresponde às práticas de racismo, gritantes desigualdades econômicas, exclusões culturais e políticas, dentre outras formas de violência.

Como se vislumbra, o princípio da igualdade se apresenta sob dois aspectos: o da igualdade formal e o da igualdade material.

A igualdade formal aparece positivada no já transcrito "caput" do artigo $5^{\circ}$ da Constituição Federal, configurando-se na igualdade perante a lei, ou seja, corresponde à identidade de direitos e deveres concedidos a todos os membros da sociedade pelos textos legais.

Contudo, consoante afirmação de Luís Pinto Ferreira ${ }^{55}$, a igualdade perante a lei não basta para resolver as contradições criadas pelo sistema de produção capitalista; o que se deve preconizar é a igualdade de oportunidade para a consecução dos objetivos da pessoa humana e para tanto é preciso que se disponham iguais condições para todos. E implica na dificuldade de se estabelecer igual oportunidade e igual condição entre homens desiguais pela capacidade pessoal de ação e direção, uma vez que a igualdade social não pressupõe um nivelamento entre homens que são naturalmente desiguais, mas o que ela realmente preconiza é a supressão das desigualdades criadas pelos privilégios da riqueza, em uma sociedade em que o trabalho e a produção são de cunho social, mas o lucro é individual.

Dai se fala em igualdade material ou substancial, que corresponde àquela que confere na prática o tratamento equânime e uniformizado de todos os seres humanos, bem como a sua equiparação no que diz respeito às possibilidades de concessão de oportunidades ${ }^{56}$.

Segundo Lenio Streck ${ }^{57}$, o novo modelo constitucional não se limita a estabelecer a igualdade formal, mas visa concretizar a igualdade material, ou seja, assume uma posição de defesa e suporte da Constituição, o que fundamenta todo o ordenamento jurídico, além de expressar uma ordem de convivência que se baseia em conteúdos materiais de vida e apresenta um projeto de superação da realidade alcançável através da integração das novas necessidades sociais.

\footnotetext{
${ }^{55}$ FERREIRA. Luís Pinto. Princípios Gerais do Direito Constitucional Moderno. São Paulo: Saraiva. 1983, p.771.

${ }_{56}$ BASTOS, Celso Ribeiro. Curso de Direito Constitucional. São Paulo: Saraiva, 1978, p.225.

${ }^{57}$ STRECK, Lenio. Op.cit., p. 283.
} 


\subsection{3 - Princípio da Legalidade}

Guilherme Nucci menciona três aspectos pelos quais se vislumbra a legalidade, quais sejam: o político, que trata o princípio da legalidade como garantia constitucional dos direitos fundamentais; o jurídico "lato sensu", traduzido pelo artigo $5^{\circ}$, inciso II da Constituição Federal; e o jurídico "stricto sensu", segundo o qual os tipos penais incriminadores apenas podem ser criados por leis em sentido estrito, ou seja, leis que são produzidas pelo Poder Legislativo e em conformidade com o processo legislativo constitucionalmente disciplinado ${ }^{58}$.

Este último está previsto no art. $5^{\circ}$, XXXIX, da Constituição Federal que preceitua não haver crime sem lei anterior que defina, nem pena sem prévia cominação legal. Corolário do Estado Democrático de Direito e emanando do texto constitucional, o princípio da legalidade se apresenta como o primeiro limite ao "jus puniendi" estatal, pois é deste princípio que parte o enfoque garantista do direito penal, segundo o qual a intervenção penal pelo Estado somente será possível se existir lei anterior que defina o fato como criminoso e a ele comine uma pena.

Mariângela Gama de Magalhães Gomes ${ }^{59}$ esclarece que o Princípio da Legalidade se apresenta sob os fundamentos da prevenção geral e da necessidade de o Poder Executivo e o Poder Judiciário se vincularem à lei abstrata. Assim, tem-se que a legalidade se origina da democracia que, por sua vez, é baseada na divisão do exercício do Poder.

Como o Direito Penal materializa a imposição de uma sanção que atinge a esfera da liberdade do indivíduo, esta pena somente se legitima a partir do momento que emana do Poder que o povo se faz mais presente: o Poder Legislativo.

Daí também decorre a noção de prevenção geral que tem por objetivo causar intimidação em potenciais delinquentes através da ameaça de uma sanção e a lei se configura o meio mais acessível para especificar qual ação é proibida, tanto porque a própria Constituição Federal expõe no inciso II do seu artigo $5^{\circ}$ que "ninguém é obrigado a fazer ou deixar de fazer alguma coisa senão em virtude de lei”.

Trata-se o princípio da legalidade, então, de verdadeira garantia constitucional em favor dos cidadãos que habitam o território de um Estado Democrático de Direito, pois configura a possibilidade de as pessoas terem conhecimento prévio de que algumas

\footnotetext{
${ }^{58}$ NUCCI, Guilherme de Souza. Código Penal comentado. 4. ed. rev., atual. e ampl. São Paulo: Revista dos Tribunais, 2003, p. 43.

${ }^{59}$ GOMES, Mariângela Gama de Magalhães. O princípio da proporcionalidade no direito penal. São Paulo: Editora Revista dos Tribunais, 2003, p.31 e 32.
} 
condutas específicas violam o ordenamento jurídico e que, caso forem praticadas, encontrarão na própria lei a respectiva sanção.

Assim, a única forma possível de legitimar a intervenção penal é pela analise da legalidade material das normas infraconstitucionais, a qual somente se verificará em relação às normas que estejam em consonância com o modelo constitucional de Estado Democrático de Direito, fundado, como dito anteriormente, no respeito e garantia dos direitos fundamentais.

Salienta Luciano Santos Lopes ${ }^{60}$ que, para o controle da legalidade, é indispensável à legitimidade da norma penal, o que somente se dará quando as normas de Direito Penal estiverem vinculadas ao plano normativo hierarquicamente superior, ou seja, em consonância com as disposições constitucionais.

Em verdade, a lei deve ter validade formal e material. Para Luigi Ferrajoli ${ }^{61}$, o sistema das normas que discorrem sobre a produção de normas se compõe de normas substanciais que limitam e vinculam o poder legislativo e também de normas formais que dispõe sobre a competência e sobre os procedimentos de formação das leis. Dessa forma, uma lei que viole algum princípio constitucional ou contradiga algum dos direitos fundamentais, por mais que tenha existência formal ou vigência, pode ser inválida e, assim, suscetível de anulação por contraste com uma norma substancial sobre sua produção.

Primeiramente a lei deve respeitar as regras de processo legislativo previstas na Constituição Federal; é isto que lhe confere validade formal e, em um Estado Democrático de Direito que realmente busque coerência com seu modelo, deve haver compatibilidade do conteúdo das normas com o conteúdo dos princípios constitucionais, ou seja, não basta que uma norma seja formalmente válida, mas ela deve ser também materialmente válida e a validade material (legitimidade) se verifica quando se contrasta uma determinada lei com as normas e os princípios constitucionais e se depreende que estão de acordo.

Assim, quando o juiz for aplicar a lei, deve analisar se os ditames desta estão de acordo com a ordem constitucional vigente, exercendo dessa forma o controle difuso de constitucionalidade.

\footnotetext{
${ }^{60}$ LOPES, Luciano Santos. Os elementos normativos do tipo penal e o princípio constitucional da legalidade. Porto Alegre: Sergio Antonio Fabris Editor, 2006, p.126.

${ }^{61}$ FERRAJOLI, Luigi. Derechos y garantias - la ley del más de débil. Trad. Perfecto Andrés Ibañez.

Madrid: Editorial Trotta, 1999, p. 66.
} 
Salo de Carvalho ${ }^{62}$ pontua o seguinte contrassenso: a facilidade de se propor um modelo garantista, discursando que o Direito é o meio para se realizar a democracia e a dificuldade de se aplicar as técnicas, tanto legislativas quanto judiciais, que visam assegurar a efetividade dos direitos fundamentais.

A legalidade vem funcionar como garantia do individuo contra o Estado, na defesa de sua liberdade, uma vez que é por ela também que se estreita o campo de atuação estatal na punição de cunho penal ${ }^{63}$.

Salienta-se que este princípio é de observância imprescindível no sistema penal de um Estado calcado às garantias e direitos fundamentais do ser humano.

Por isso, em relação ao Direito Penal, o Princípio da Legalidade apresenta três vertentes, quais sejam: reserva legal, taxatividade e irretroatividade da lei penal.

Luiz Regis Prado explica que pela reserva legal se entende que o domínio da lei disciplina a intervenção penal, evitando, dessa forma, que o poder de punir do Estado seja exercido de maneira arbitrária e sem limites, e, em contrapartida, apresenta-se como garantia individual do cidadão que protege a liberdade deste perante o Estado - Juiz, o Estado - Administração e o Estado - Legislador ${ }^{64}$.

Este autor esclarece que da reserva legal emanam as seguintes garantias: as de cunho criminais e penais, uma vez que somente a lei formal é fonte criadora de crimes e de penas, o que reveste de inconstitucionalidade a utilização de qualquer outro ato normativo para incriminar e apenar condutas; e as garantias jurisdicionais e de execução, que asseguram que ninguém será processado nem sentenciado senão pela autoridade competente (artigo $5^{\circ}$ inciso LVIII da Constituição Federal), bem como que a sanção penal será executada na forma da lei ${ }^{65}$.

Já pela vertente da irretroatividade da lei, que vem expressa no artigo $5^{\circ}$ inciso XL da Constituição Federal e é endossada pelo artigo $2^{\circ}$ do Código Penal, tem-se que "a lei penal não retroagirá, salvo quando para beneficiar o réu".

Segundo Mariângela Gama de Magalhães Gomes ${ }^{66}$, este postulado se relaciona com a validade da lei penal no tempo e obsta que o legislador introduza ou agrave penas posteriormente ao cometimento do fato. Isto aconteceria, por exemplo, para acalmar o

\footnotetext{
${ }^{62}$ CARVALHO, Salo de. Pena e Garantias: uma leitura do garantismo de Luigi Ferrajoli no Brasil. Rio de Janeiro: Lumen Juris, 2001, p.108.

${ }^{63}$ LOPES, Luciano Santos. Op.cit., p. 84.

${ }^{64}$ PRADO, Luiz Regis. Bem jurídico penal e Constituição. 4.ed.rev., atual. e ampl. São Paulo: Editora Revista dos Tribunais, 2009, p. 57.

${ }^{65}$ Idem, p. 58.

${ }^{66}$ GOMES, Mariângela Gama de Magalhães. Op.cit.,p. 33.
} 
clamor público que se evidencia quando a sociedade resta impressionada com a ocorrência de um crime de proporções escandalosas.

A taxatividade da lei, por sua vez, limita a discricionariedade do órgão judicial no momento da aplicação da pena. Para Luiz Regis Prado ${ }^{67}$, este princípio derivado da legalidade e que também se denomina determinação, obriga o legislador descrever o fato punível da forma mais clara possível para que se cumpra a exigência de que o conteúdo da lei possa ser conhecido por todos os cidadãos, o que permitirá que se distinga a licitude da ilicitude.

\subsection{4 - Princípio da Proporcionalidade}

O que caracteriza basicamente o Estado Democrático de Direito é existência de direitos oponíveis ao Poder Público, como forma de se tutelar a esfera privada da vida das pessoas e que somente será objeto de sacrifício quando indispensável e, ainda assim, haverá de guardar a menor extensão possível, pois, em um Estado de Democrático de Direito almeja-se a realização dos direitos dos cidadãos ${ }^{68}$.

Desta feita, quando houver premente necessidade de se restringir algum ou alguns dos direitos inerentes ao cidadão, a intervenção do Poder Público no âmbito privado deve ser mínima para poder ser considerada legítima, pois, caso contrário, revelar-se-á abusiva.

Segundo Paulo Bonavides ${ }^{69}$, utiliza-se assiduamente o princípio da proporcionalidade para aferição da constitucionalidade dos atos do Estado, no exercício do “jus puniendi” ou do "jus persecuendi", a fim de proteger os direitos fundamentais.

Em verdade, esta ideia advém de Luigi Ferrajoli ${ }^{70}$, uma vez que este autor construiu toda a tese do sistema garantista sobre os pilares do princípio da proibição do excesso, o qual decorre do princípio proporcionalidade e limita a atuação estatal quando esta se volta para a restrição da liberdade individual.

Em suma, a teoria de Luigi Ferrajoli visa restringir o "jus puniendi" do Estado, limitando sensivelmente sua atuação na esfera individual dos cidadãos.

Quando se trata de o Estado utilizar o Direito Penal como mecanismo de controle social, sua incidência deve apresentar-se adequada, necessária e proporcional para que se

\footnotetext{
${ }^{67}$ PRADO, Luiz Regis. Op.cit., p. 59.

${ }^{68}$ SILVA, José Afonso da. Op.cit., p. 232.

${ }^{69}$ BONAVIDES, Paulo. Op.cit., p. 359.

${ }^{70}$ FERRAJOLI, Luigi. Direito e razão - teoria do garantismo penal. 2. ed. São Paulo: Editora Revista dos Tribunais, 2006, p. 09.
} 
possa considerá-la satisfatória; é o que traz o princípio da proporcionalidade, tendente a dirimir eventuais conflitos entre bens jurídicos fundamentais.

Entende-se este princípio, então, como a necessidade de haver proporção entre o grau de lesão a determinado bem jurídico-penal e a pena a esta prevista.

Robert Alexy $^{71}$ afirma que o princípio da proporcionalidade obriga o operador do Direito à análise de três aspectos, quais sejam: o da adequação, o da necessidade e o da proporcionalidade em sentido estrito. Afirma também que a solução para os eventuais conflitos entre os princípios exige um exercício valorativo de ponderação por meio do qual se verifica qual deles tem peso maior para a questão concreta a ser decidida.

Cumpre analisar, ainda que de maneira sucinta, cada qual dos três subprincípios que compõem o princípio da proporcionalidade e por meio dos quais a proporcionalidade se exterioriza.

Primeiramente, a adequação exige que o fim pretendido pela norma e os meios por ela enunciados para a consecução deste fim sejam compatíveis entre si e com o Direito, ou seja, examina-se a relação de causalidade entre a finalidade da lei e o método que levará a ela, de modo que, uma lei somente deve ser afastada por inidônea quando absolutamente incapaz de produzir o resultado perseguido ${ }^{72}$.

A necessidade, por sua vez, concerne à indispensabilidade da medida restritiva de direitos para que o bem jurídico por ela restringido seja preservado; este é um juízo de valor tecido a fim de se lograr a importância do direito e a inexistência de meio menos lesivo para se protegê-lo ${ }^{73}$. Com este juízo de valoração, busca-se o meio menos nocivo capaz de produzir o fim propugnado pela norma em questão.

José Joaquim Gomes Canotilho ${ }^{74}$ enxerga quatro vertentes nas quais este subprincípio se dissipa, quais sejam: a exigibilidade material, no que tange a indispensabilidade da restrição; a espacial, que obriga a delimitação do âmbito de atuação da medida; a temporal, no sentido de que a medida coercitiva do Poder Público não deve ser perpétua, mas ter prazo certo previamente estipulado e improrrogável; e a pessoal, uma vez que a medida deve ser restrita ao conjunto de pessoas que deverão ter seus interesses sacrificados, sem que, com ela, se afete a esfera privada e individual de terceiros alheios à situação.

\footnotetext{
${ }^{71}$ ALEXY, Robert Teoria de Los Derechos Fundamentales. Trad. Ernesto Garzón Vladés. Madri: Centro de Estúdios Políticos y Constitucionales, 2001, p. 160.

${ }^{72}$ Idem, p. 161.

${ }^{73}$ Idem, p. 162.

${ }^{74}$ CANOTILHO, José Joaquim Gomes. Direito constitucional e teoria da constituição. Coimbra. Almedina. 1998 , p. 262.
} 
Finalmente, o subprincípio da proporcionalidade em sentido estrito concerne a um sistema de valoração que visa garantir um direito, restringindo outro ${ }^{75}$.

Para a Raquel Denise Stumm ${ }^{76}$, esta situação somente se faz admissível do ponto de vista jurídico após a cuidadosa realização de um estudo teleológico, do qual se venha concluir que o direito protegido por determinada norma jurídica detenha conteúdo superior ao que será restringido.

José Joaquim Gomes Canotilho ${ }^{77}$ sintetiza o juízo de proporcionalidade como sendo aquele que tende a lograr um equilíbrio entre o fim almejado e o meio empregado para alcançá-lo, ou seja, o resultado que se obterá com a intervenção na esfera de direitos do particular deve ser proporcional à carga coercitiva que esta intervenção traz em seu bojo.

Deste breve apanhado sobre os três aspectos que se deve observar quando da realização do juízo de proporcionalidade, insta frisar a afirmação de Humberto Ávila no sentido de que o princípio da proporcionalidade exige que o Poder Legislativo e o Poder Executivo escolham meios adequados, necessários e proporcionais para a realização de seus fins. Um meio é adequado se promove um fim. Um meio é necessário se for menos restritivo relativamente aos direitos fundamentais dentre todos aqueles meios igualmente adequados para promover o fim. E um meio é proporcional, em sentido estrito, se as vantagens que promove superam as desvantagens que provoca ${ }^{78}$.

\subsection{5 - Princípio da Intervenção Mínima}

Afirma Paulo Queiroz que "o direito penal não é uma exigência natural, moral, divina ou transcendental de qualquer tipo; é, isto sim, uma opção política com vistas a assegurar a preservação de determinados interesses vitais ${ }^{79,}$.

Para proteger bens e interesses de grande valor social e evitar a transgressão às normas, o Estado impõe a mais grave sanção jurídica através da incriminação de certas condutas e aplicação de penalidades ${ }^{80}$.

\footnotetext{
${ }^{75}$ ALEXY, Robert. Op.cit., p. 162.

${ }^{76}$ STUMM, Raquel Denise. Princípio da Proporcionalidade no Direito Constitucional Brasileiro. Porto Alegre, Livraria do Advogado Editora, 1995, p.81.

${ }^{77}$ CANOTILHO, José Joaquim Gomes. Op.cit., p. 263.

78 ÁVILA, Humberto. Teoria dos princípios: da definição à aplicação dos princípios jurídicos. São Paulo: Malheiros Editores, 2007, p. 158.

${ }^{79}$ QUEIROZ, Paulo. Funções do direito penal: legitimação versus deslegitimação do sistema penal. 2. ed. rev., atual e ampl. São Paulo: Editora Revista dos Tribunais, 2005, p.116.

${ }^{80}$ FRAGOSO, Heleno Cláudio. Lições de direito penal: parte geral. 15. ed. rev. e atual. Rio de Janeiro: Forense, 1994, p. 275.
} 
Como já mencionado, o Direito Penal corresponde ao mecanismo de controle social mais gravoso, pois incide de modo mais contundente na esfera de direitos individuais da pessoa humana.

Por isso Francisco Muñoz Conde ${ }^{81}$ sustenta que o poder punitivo do Estado deve estar regido e limitado pelo princípio da intervenção mínima, segundo o qual se concebe o direito penal como "ultima ratio", ou seja, a última medida de tutela estatal a bens jurídicos, que deve ser utilizada somente quando se revelar estritamente necessária para a garantia de direitos fundamentais.

Isso significa que as sanções de cunho penal somente serão impostas em casos previamente estipulados em lei e que se configurem ofensas significativas aos bens jurídicos mais importantes, e que os outros ramos do Direito não conseguem amparar de maneira satisfatória.

Assim, se qualquer outro ramo do Direito proteger de maneira eficiente determinados bens jurídicos, não haverá necessidade de atuação do direito penal. Devido ao caráter residual que o Direito Penal assume este princípio também é denominado princípio da subsidiariedade.

Cezar Roberto Bitencourt ${ }^{82}$ explica que o princípio da intervenção mínima limita o poder penal violento do Estado, orientando-o. Para que o "jus puniendi" seja exercido, é preciso que se esgotem todos os meios extrapenais de controle social existentes.

No entendimento de Rene Ariel Dotti ${ }^{83}$, o princípio da intervenção penal mínima foi recepcionado pela Constituição através da cláusula geral prevista no parágrafo $2^{\circ}$ do artigo $5^{\circ}$, a qual dispõe que "os direitos e garantias expressos nesta Constituição não excluem outros decorrentes do regime e dos princípios por ela adotados, ou dos tratados internacionais em que a República Federativa do Brasil seja parte”.

De acordo com o mesmo autor, ${ }^{84}$ há casos em que não é justificável a intervenção penal mesmo que a lesão seja considerável, porque pode ser possível coibir o ilícito por meio de sanções civis ou administrativas, por isso, tem-se que o princípio da intervenção mínima visa diminuir o número de normas incriminadoras se vinculando mais ao legislador.

\footnotetext{
${ }^{81}$ MUÑOZ CONDE, Francisco. Introducción al derecho penal. 2.ed. Aboso. Montevideo - Buenos Aires, 2003, p. 59-60.

${ }^{82}$ BITENCOURT, Cezar Roberto. Tratado de Direito Penal. Parte Geral. Vol.I, 2003, p. 11.

${ }^{83}$ DOTTI, Rene Ariel. Curso de direito penal: parte geral. 2. ed., rev. atual. e ampl. Rio de Janeiro: Forense, 2005 , p. 36.

${ }^{84}$ Idem, p. 37.
} 
O princípio da intervenção penal mínima desempenha a função de assegurar as garantias individuais previstas na Constituição. Nesse sentido são os estudos de Fernando Galvão $^{85}$ que considera o princípio em análise como sendo a expressão do axioma da "nulla lex (poenalis) sine necessitate", o qual, por sua vez, determina não ser possível a incriminação legal sem que haja a necessidade de uma intervenção tão gravosa quanto à promovida pelo Direito Penal".

Segundo Luiz Regis Prado $^{86}$, o princípio da intervenção mínima pressupõe que a tutela penal só deve tratar daqueles bens jurídicos fundamentais da sociedade e se não existirem outros métodos eficientes para assegurar as condições de vida, bem como o desenvolvimento e a paz social, e que tais métodos também sejam calcados nos ideais da liberdade e da dignidade da pessoa humana.

O princípio da intervenção mínima apresenta duas características, quais sejam, a fragmentariedade e a subsidiariedade, que complementam seu conteúdo.

Cezar Roberto Bitencourt ${ }^{87}$ explica a característica da fragmentariedade sustentando que nem todas as ações que lesionam bens jurídicos são proibidas pelo Direito Penal, como nem todos os bens jurídicos são por ele protegidos; desta feita, o Direito Penal limita-se a castigar as ações mais graves praticadas contra os bens jurídicos mais importantes, decorrendo daí o seu caráter fragmentário.

O caráter fragmentário significa então que somente uma diminuta parcela de condutas deve ser tutelada pelo Direito Penal.

Paulo Queiroz explica que a proteção conferida pelo Direito Penal se condifera fragmentária, pois este ramo do Direito se concentra sobre fragmentos da realidade e não sobre o todo ${ }^{88}$.

Este mesmo autor assevera que o Direito Penal, como mecanismo de controle social, é apenas um meio, um instrumento a serviço dos fins que a Constituição outorga ao Estado; não é o mais importante nem o mais indicado, mas, por ser o braço armado da Magna Carta, deve ser o último guardião da juridicidade ${ }^{89}$.

Já a característica da subsidiariedade, por sua vez, determina que o Direito Penal seja utilizado como mecanismo de controle social apenas quando falham as defesas do bem jurídico predispostas por outros ramos do Direito.

\footnotetext{
${ }^{85}$ ROCHA, Fernando A. N. Galvão da. Direito penal - parte geral. Rio de Janeiro: Impetus, 2004, p. 90.

${ }^{86}$ PRADO, Luiz Regis. Op.cit., p.56-60.

${ }^{87}$ BITENCOURT, Cezar Roberto. Op.cit., p. 12.

${ }^{88}$ QUEIROZ, Paulo. Op.cit., p. 119.

${ }^{89}$ Idem, p. 132.
} 
O caráter subsidiário do Direito Penal pressupõe, então, que o sistema penal, por ser o de consequências mais extremas em relação aos direitos do ser humano, deve ser remédio último, somente se legitimando quando os demais ramos do Direito se revelarem incapazes de dar a devida tutela a bens de relevância para a própria existência do homem e da sociedade ${ }^{90}$.

Nesse sentido, Francisco Muñoz Conde ${ }^{91}$ explana que o Direito Penal possui um caráter que confirma e assegura as outras instâncias do Direito, as quais, por isso, revelamse mais eficazes apesar de apresentarem incidência mais sutil, isto porque a norma penal não enseja novos valores nem constitui um sistema autônomo de motivação do comportamento humano em sociedade, mas tem sentido apenas se for considerada como parte derivada de um conjunto de instituições públicas e privadas, responsáveis diretamente pelo controle social informal e cuja tarefa consiste em socializar e educar para a convivência os indivíduos através da aprendizagem e internalização de determinadas pautas de comportamento.

Disso se depreende que direito penal deve proteger apenas alguns bens jurídicos que estejam ligados aos direitos fundamentais. Como consequência da aplicação dos demais princípios à atividade legislativa, esta elegerá somente alguns bens como bens jurídicopenais, e não todos os bens objeto de proteção de todo o ordenamento jurídico.

\subsection{6 - Princípio da Adequação Social}

Alude este princípio que, apesar de típica sob o aspecto formal, uma conduta somente pode ser considerada materialmente típica quando se manifestar discrepante das práticas culturais e costumeiras incorporadas na sociedade em que o fato foi praticado.

Somente são materialmente típicos os comportamentos que destoam dos comportamentos sociais naturalmente aceitos e praticados pela coletividade. Por este princípio se conclui que a tipicidade formal corresponde tão somente à análise da subsunção do fato à norma, ao passo que tipicidade material corresponde à análise da efetiva lesão criada pela conduta do agente a bens, expectativas ou valores sociais ${ }^{92}$.

Essa concepção material do tipo torna-se a vertente cientificamente mais adequada para que se descriminalizem condutas que, embora se revelem típicas sob o prisma da

\footnotetext{
${ }^{90}$ LUISI, Luiz. Os princípios constitucionais penais. 2. ed. Porto Alegre: Sergio Antonio Fabris, 2002, p. 40.

${ }^{91}$ CONDE, Francisco Muñoz. Op.cit., p. 61.

${ }^{92}$ WELZEL, Hans. Direito Penal. Tradução de Afonso Celso Rezende. Campinas: Romana, 2004, p. 106.
} 
formalidade, não mais se fazem objeto de reprovação social, tampouco produzem danos significativos aos bens jurídicos protegidos pela norma penal ${ }^{93}$.

Segundo Luiz Regis Prado ${ }^{94}$ a teoria da adequação social concebida por Hans Welzel enseja que, apesar de uma conduta se subsumir ao texto da lei penal, não será considerada típica se for socialmente adequada ou reconhecida, isto é, se estiver de acordo com a ordem social da vida, historicamente condicionada.

Referido autor salienta ainda que as condutas socialmente adequadas não são necessariamente exemplares, mas apenas condutas que se mantém dentro dos marcos de liberdade da ação social e que estejam em conformidade ao direito, ou seja, que apresentam uma concordância com determinações jurídicas de comportamento já estabelecidas, portanto, este princípio revela-se um instrumento de interpretação restritiva, calcado no aspecto material do tipo penal. Por ele se torna possível alcançar a proposta político-criminal da necessidade de descriminalização de condutas que, embora formalmente típicas, não atingem os bens protegidos pelo Direito Penal, em razão da sua adequação, e sem macular a segurança jurídica do sistema ${ }^{95}$.

Isto porque a tipicidade não se esgota no juízo lógico-formal de subsunção do fato ao tipo legal de crime. A ação descrita tipicamente deve revelar-se, ainda, inadequada e ofensiva para o bem jurídico protegido pela lei penal.

Não obstante, verifica-se que a tipicidade continuou a ser um mero juízo formal de subsunção da adequação de um fato à descrição da lei penal, desde a evolução teórica do tipo até o finalismo, e esta concepção não satisfaz a moderna característica subsidiária do Direito Penal Constitucional de intervir apenas quando os outros meios de controle social não se mostrarem eficientes. Diante disso, vislumbrou-se que o tipo possui também um caráter material, ou seja, para um determinado comportamento ser considerado típico não basta que somente esteja ajustado formalmente a um artigo de lei penal incriminadora, mas há de revelar-se também lesivo do ponto de vista material aos bens jurídicos e, consequentemente, deve ser ética e socialmente reprovável ${ }^{96}$.

Para que o juízo de tipicidade não atinja fatos alheios ao direito penal por sua aceitação pela sociedade ou pelo dano social ser de caráter irrelevante, deve-se assimilar o

\footnotetext{
${ }^{93}$ LOPES, Mauricio Antônio Ribeiro. Princípio da insignificância no direito penal: análise à luz das leis 9.009/95 (juizados especiais criminais), 9.503/97 (código de trânsito brasileiro) e da jurisprudência atual. 2. ed., rev. atual. e ampl., São Paulo: Revista dos Tribunais, 2000, p. 54.

${ }^{94}$ PRADO, Luiz Regis. Curso de direito penal brasileiro - Parte geral. Vol. 1. 3.ed., São Paulo: Revista dos Tribunais, 2002, p. 154.

95 Idem.

${ }^{96}$ LOPES, Mauricio Antônio Ribeiro. Op.cit., p.54.
} 
tipo em sua concepção material, ou seja, como conceito munido conteúdo valorativo, de amplo eminentemente diretivo ${ }^{97}$.

Assim, faz-se de premente necessidade considerar materialmente atípicas as condutas lesivas de inequívoca insignificância para a vida em sociedade, a fim de se conferir validade sistemática à irrefutável conclusão político criminal de que o direito penal somente pode incidir nas situações que realmente necessitem de proteção ao bem jurídico, não lhe sendo dado ocupar-se de bagatelas.

Pela adoção do princípio da adequação social determinadas condutas como lesões corporais oriundas de competições esportivas, a circuncisão, a intervenção cirúrgica realizada com o consentimento do paciente, ou ainda a destruição de coisa alheia realizada por empresa de demolição regularmente contratada, que, formalmente, configuram-se fatos típicos, não seriam materialmente consideradas como condutas típicas, uma vez que se encontram inseridas no campo da normalidade das relações sociais ${ }^{98}$.

Tem-se que o princípio da adequação social se fundamenta no seguinte: partindo-se da premissa que, ao elaborar os tipos de injusto penal, o legislador analisa a realidade fenomênica das relações sociais e elenca os modelos de condutas que são desvaloradas socialmente, então, não seria lógico pretender que os tipos penais tivessem amplitude tamanha ao ponto de incluir em sua zona de abrangência também os comportamentos considerados corretos pela sociedade.

Portanto, as condutas consideradas adequadas do ponto de vista social não se subsumem aos tipos penais de injusto por não terem em si incutidas o desvalor que motiva a criminalização de certos comportamentos que o legislador considera como ilícitos.

\subsection{7 - Princípio da Culpabilidade}

O princípio da culpabilidade fundamenta o Direito Penal e implica na inadmissibilidade de penas que não atinjam a prevenção geral e a especial; é por este princípio que se mensura as penas que serão impostas ao agente ${ }^{99}$.

Este princípio, juntamente com os outros analisados anteriormente, serve de fundamento e norteia a aplicação da pena ao indivíduo.

\footnotetext{
${ }^{97}$ Idem, p. 53.

${ }^{98}$ SANTORO FILHO, Antonio Carlos. Teoria do tipo penal. São Paulo: Editora de Direito, 2001, p.108 e 109.

${ }^{99}$ GÜNTHER, Klaus. A culpabilidade no Direito Penal atual e no futuro.Tradução de Juarez Tavares. Doutrina Internacional. Revista Brasileira de Ciências Criminais, ano 6, n. 24. São Paulo: Editora Revista dos Tribunais, outubro-dezembro 1998, p. 80.
} 
Mensura-se a culpabilidade quando, ao se impor uma pena, deve-se respeitar o limite superior que a lei prevê abstratamente, o que funciona como uma barreira à faculdade de intervenção estatal, protegendo o indivíduo e impedindo que se extrapole no controle que incidirá sobre sua liberdade pessoal.

A primeira abordagem, então, do princípio da culpabilidade concerne à sua função limitadora do intervencionismo estatal e que defende o agente de eventuais excessos e arbitrariedades que possam ser praticados pelo Estado no exercício do direito de punir.

Na concepção de Francesco C. Palazzo, o princípio constitucional da culpabilidade é dúplice, pois se inscreve ora como fundamento da pena e do próprio "jus puniendi", ora como limite da intervenção punitiva do Estado ${ }^{100}$.

Isso significa que referido princípio baliza a aplicação da pena, legitimando-a e, ao mesmo tempo, cuidando para que a sanção penal não extrapole os limites da reprovabilidade da conduta criminosa e nem atropele a dignidade humana.

Outro aspecto do princípio da culpabilidade corresponde à consagração da responsabilidade penal subjetiva e consequente vedação da atribuição objetiva da sanção penal, ou seja. Acerca disso, Luiz Luisi ${ }^{101}$ ressalta que um dos princípios constitucionais que aparece em muitas Constituições contemporâneas, inclusive a brasileira, e serve de base para o sistema penal é o da responsabilidade subjetiva, ou seja, da culpabilidade.

Nilo Batista leciona que o principio da culpabilidade comporta dois entendimentos. Primeiramente, deve ser entendido como repúdio a qualquer espécie de responsabilidade pelo resultado ou responsabilidade objetiva. Em segundo lugar, a dinâmica de um Estado Democrático de Direito traz a exigência de que a pena não seja infligida senão quando a conduta do sujeito, mesmo associada causalmente a um resultado, lhe seja reprovável ${ }^{102}$.

As explicações deste autor acerca do entendimento e da importância do princípio da culpabilidade para o ordenamento jurídico pátrio seguem no sentido de que não cabe mais no direito penal moderno uma responsabilidade objetiva que deriva de uma simples associação causal entre a conduta e um resultado de lesão ou perigo para um bem jurídico, mas a culpabilidade do agente é indispensável, tanto que, no âmbito do processo penal, há exigência de provas quanto a esse aspecto pelo aforismo ‘culpabilidade não se presume'. A responsabilidade penal é sempre subjetiva ${ }^{103}$.

\footnotetext{
${ }^{100}$ PALAZZO, Francesco C. Op.cit., p. 52.

${ }^{101}$ LUISI, Luiz. Op.cit., p. 32.

${ }^{102}$ BATISTA, Nilo. Introdução Crítica ao Direito Penal Brasileiro, $9^{a}$ ed. Rio de Janeiro: Editora Revan, 2004, p. 103.

${ }^{103}$ Idem, p. 104.
} 
Luiz Régis Prado frisa a importância desse princípio para todo o ordenamento penal. Considera este autor que o princípio em análise constitui expressão de justiça material peculiar ao Estado de Direito Democrático, uma vez que delimita toda a responsabilidade penal; esta função o faz postulado basilar de que não há pena sem culpabilidade (nulla poena sine culpa) e de que a pena não pode ultrapassar a medida da culpabilidade ${ }^{104}$.

No Direito brasileiro, encontra-se ele implicitamente agasalhado, em nível constitucional, no artigo $1^{\circ}$, III (dignidade da pessoa humana), corroborado pelos artigos $4^{\mathrm{o}}$, II (prevalência dos direitos humanos), 5º caput (inviolabilidade do direito à liberdade), e $5^{\circ}$, XLVI (individualização da pena), da Constituição da República Federativa do Brasil ${ }^{105}$.

As lições transcritas denotam que a doutrina considera o princípio da culpabilidade como um dos pilares de sustentação do Direito Penal contemporâneo e as suas acepções refletem sobre todo o ordenamento jurídico-penal brasileiro. As duas significações que mais importam em amplitude de princípio constitucional correspondem à questão da responsabilidade penal, que, ante a vedação constitucional da responsabilidade penal objetiva no ordenamento jurídico brasileiro, somente poderá figurar na forma subjetiva; e a que se refere à culpabilidade como fundamentação da pena.

Disso se depreende que o princípio da culpabilidade exerce função garantidora da dignidade da pessoa humana.

Insta atentar às considerações de Cláudio Brandão ${ }^{106}$ no sentido de que o princípio da culpabilidade, ao traduzir a responsabilidade penal do homem, condiciona o método do direito penal, porque se faz ele um dos mecanismos para a ponderação do caso concreto no processo da decisão e da argumentação jurídica, o que possibilita a realização da tópica que, para garantir o respeito à dignidade humana pode superar o silogismo.

$\mathrm{O}$ autor cita como exemplos de seus dizeres acima o fato de quando se reconhecem causas supralegais de inexigibilidade de conduta diversa, que é causa de exclusão da culpabilidade. Segundo este entendimento, reconhece-se, assim, a insuficiência do silogismo legal, que não contempla tais causas, valorizando-se o homem pelo reconhecimento de circunstâncias concretas que devem afastar a aplicação do tipo penal. E assim se configura o uso da tópica para argumentar a liberdade, o que confirma que o

\footnotetext{
${ }^{104}$ PRADO, Luiz Regis. Curso de direito penal brasileiro, volume 1: parte geral: arts. $1^{\circ}$ a 120.3 . ed. rev. atual. e ampl. São Paulo: Revista dos Tribunais, 2002, p. 117.

105 Idem.

${ }^{106}$ BRANDÃO, Cláudio. Culpabilidade: sua análise na dogmática e no direito penal brasileiro. Revista da associação brasileira de professores de ciências penais. São Paulo: Revista dos Tribunais, v. 1, ano 1, p.171184, jul./dez. 2004, p. 178.
} 
homem é um ser reconhecido em sua dignidade no direito penal, sendo, no âmago, o próprio fim desse direito. Eis aí a fundamentação da culpabilidade como princípio ${ }^{107}$.

Vislumbra-se, então, que não há como falar em culpabilidade em um Estado Democrático de Direito sem ter por amparo a dignidade da pessoa humana, visto que esta serve como valor inerente ao princípio da culpabilidade e, ainda, quando a lei não apresentar silogisticamente solução ao caso, deve-se recorrer à tópica, método este que analisa o caso concreto e faz com que se respeite referido princípio, atingindo-se a tão almejada justiça na esfera criminal, ou seja, o princípio em análise deve ser respeitado por ser mecanismo garantidor da dignidade da pessoa humana e de toda a estrutura do Estado Democrático de Direito prescrito pela Constituição da República Federativa do Brasil.

Além disso, o princípio da culpabilidade se configura como aquele que traz ao indivíduo e à coletividade a segurança de uma pena justa, que seja proporcional à culpabilidade pessoal do autor do delito e que obste penas excessivas ou desproporcionais à gravidade do fato.

Salienta Claus Roxin ${ }^{108}$ que as maiores conquistas do princípio da culpabilidade foram a eliminação do acaso e a superação do direito penal do resultado.

\subsubsection{1 - Culpabilidade como fundamento da pena}

Serve o princípio da culpabilidade como fundamento da pena, o que assegura a máxima constitucional da dignidade da pessoa humana.

Claus Roxin afirma que a relevância do conceito de culpabilidade transcende ao Direito Penal, pois apresenta dimensões sociais, éticas, religiosas e até mesmo políticas ${ }^{109}$.

Assinala Luiz Regis Prado que "a culpabilidade deve ser entendida como fundamento e limite de toda pena. Esse princípio diz respeito ao caráter inviolável do respeito à dignidade do ser humano" 110 .

De acordo com os ensinamentos de Francesco C. Palazzo, dizer que o princípio de culpabilidade serve como fundamento da pena significa conferir a característica de retribuição à culpabilidade, o que tende a uma compensação do mal produzido pelo autor, uma vez que este reflete a cattiva volontá do réu. A culpabilidade, como fundamento da pena, coloca o homem no centro do sistema penal, como sujeito de responsabilidade moral,

\footnotetext{
107 Idem

${ }^{108}$ ROXIN, Claus. Estudos de Direito Penal. Tradução Luís Greco. 2.ed. Rio de Janeiro: Renovar, 2008, p. 135.

${ }^{109}$ Idem, p. 134.

${ }^{110}$ PRADO, Luiz Regis. Op.cit., p. 117.
} 
entendido, pois em sua característica capacidade de autodeterminação. Desta forma, o princípio de culpabilidade incide constitucionalmente no princípio da intangibilidade da dignidade humana ${ }^{111}$.

Também neste sentido é a lição de Hans Heinrich Jescheck, segundo a qual o princípio da culpabilidade serve como proteção necessária do cidadão em face de qualquer excesso na intervenção repressiva do Estado, denotando a preocupação de que a pena se limite estritamente a condutas que merecem um juízo de desvalor ético-social ${ }^{112}$.

A lição de Santiago Mir Puig assevera fundar-se o princípio da culpabilidade no princípio da dignidade humana como resultado das premissas basilares de um Estado Democrático que prima o indivíduo. Segundo este autor, a dignidade humana possibilita que o indivíduo evite a pena comportando-se em consonância com o Direito ${ }^{113}$.

Tem-se, então, que o princípio da culpabilidade como fundamento da pena pode ser entendido como medida necessária para a manutenção da dignidade da pessoa humana intangível no Estado Democrático de Direito instituído pela Constituição de 1988, bem como para se alcançar os próprios objetivos constitucionais contidos no artigo $3^{\circ}$ da Magna $\operatorname{Carta}^{114}$.

Márcia Dometila de Carvalho se ampara nas lições de Francesco C. Palazzo e considera o princípio da culpabilidade um princípio de direito justo, porque ele fundamenta e limita a pena; fundamentando a pena, o princípio da culpabilidade fornece a ela o caráter retributivo, que demonstra a face ética do Direito Penal e que tem por foco o homem, cuja responsabilidade provém de sua dignidade de pessoa e, por isso, torna-se capaz de sofrer reprovabilidade; e limitando a pena, o princípio da culpabilidade proíbe que o Estado cometa abusos da sanção punitiva, o que confere ao Direito Penal um cunho humanitário que veda aquela visão utilitarista de instrumentalização do homem para satisfação do bem comum $^{115}$.

\footnotetext{
${ }^{111}$ PALAZZO, Francesco C. Op.cit., p. 52-53.

112 JESCHECH, Hans Heinrich. El Principio de Culpabilidad Como Fundamento Y Límite De La Punibilidade En El Derecho Alemán Y Español. San Sebastián: Eguzkilore - Cuaderno del Instituto Vasco de Criminología, no 9, 1995, p. 28 e 29.

${ }^{113}$ MIR PUIG, Santiago. Derecho penal - parte general. $5^{\text {a }}$ edición. Barcelona: 1998, p. 97.

${ }^{114}$ BRASIL. Constituição da República Federativa do Brasil. Brasília: Senado, 1988. Art. $3^{\circ}$. Constituem objetivos fundamentais da República Federativa do Brasil: I - construir uma sociedade livre, justa e solidária; II - garantir o desenvolvimento nacional; III - erradicar a pobreza e a marginalização e reduzir as desigualdades sociais e regionais; IV - promover o bem de todos, sem preconceitos de origem, raça, sexo, cor, idade e quaisquer outras formas de discriminação.

${ }^{115}$ CARVALHO, Marcia Dometila Lima de. Fundamentação constitucional do direito penal. Porto Alegre: Sergio Antonio Fabris, 1992, p. 64.
} 
Desta feita, o conteúdo do princípio da culpabilidade deve ter coerência com o conceito de ser humano que inspira a Constituição Federal brasileira, haja vista, um Estado Democrático de Direito se baseia na concepção do homem como pessoa, como um ser responsável e capaz de autodeterminação conforme critérios normativos.

A liberdade, como característica inerente da pessoa, é o pressuposto irrenunciável de toda a responsabilidade penal e do modelo político-criminal de um Estado de Direito Democrático. Apenas neste sentido é dado falar da dignidade pessoal com o valor mais alto e o bem mais digno de proteção de toda a ordem jurídica constitucional.

Juarez Tavares assevera que o Estado Democrático, por ser essencialmente voltado à proteção da dignidade humana e se orientar no sentido da proteção constitucional ao pluralismo político, deve ser entendido juridicamente como um Estado garantidor das liberdades individuais, das características diversificadas de cada um de seus cidadãos, bem como deve viabilizar a realização integral das potencialidades humanas e de sua concreta execução dentro de uma política de integração e de participação ${ }^{116}$.

Ricardo Antunes Andreucci ${ }^{117}$ também correlaciona a culpabilidade com a dignidade da pessoa humana, salientando que, para que se tenha um direito penal mais humano, o centro da estrutura jurídica do crime deve ser a pessoa, ou seja, o juízo de reprovação deve recair sobre a conduta do agente e esta conduta deve ser analisada e valorada em todo seu contexto antes de se aplicar a pena para que, quando esta vier a incidir sobre o infrator, seja dosada de modo proporcional.

Disso se depreende que o princípio da culpabilidade é uma exigência do respeito à dignidade humana do indivíduo, porque a imposição de uma pena sem culpabilidade enseja a utilização do ser humano como instrumento para a consecução preventiva de fins sociais, o que corresponde a um grave atentando à sua dignidade enquanto pessoa.

Além disso, seu fundamento constitucional é dúplice, pois ora se inscreve como fundamento da pena e do próprio "jus puniendi", ora como limite da intervenção punitiva do Estado.

Pode-se dizer que, como fundamento da pena, o princípio da culpabilidade projeta o sistema penal sob uma perspectiva ética que tem por foco o ser humano como sujeito de responsabilidade moral, devido à capacidade de autodeterminação para o mal e para o bem que lhe é característica.

${ }^{116}$ TAVARES, Juarez. Culpabilidade: A Incongruência dos Métodos. Revista Brasileira de Ciências Criminais, ano 6, n 24. São Paulo: Editora Revista dos Tribunais, out-dez 1998, p. 151.

${ }^{117}$ ANDREUCCI, Ricardo Antunes. Dimensão humana e direito penal. José Bushatsky Editor, Revista Ciência Penal, Vol. 2, 1974, p. 211. 
Já como limite da pena, o princípio em análise responde à exigência de evitar que o Estado abuse de seu poder punitivo para alcançar a finalidade preventiva da pena e ainda projeta o sistema sob uma perspectiva utilitarista na qual o maior perigo é o de instrumentalização do homem.

Observa-se que o princípio da culpabilidade reflete ainda uma questão que atine ao próprio Estado no que tange à sua legitimidade e capacidade de exigir responsabilidade das pessoas, ou seja, a culpabilidade faz com que o Estado demonstre sua condição para exigir do indivíduo o cumprimento das normas jurídicas, e evidentemente tal capacidade de exigir varia de acordo com cada pessoa, suas circunstâncias pessoais e sua relação com o próprio Estado.

Contudo, o princípio da culpabilidade não estabelece os caracteres da reprovação no exame jurídico penal de maneira absoluta. Ao aludir a culpabilidade como fundamento da pena, Cezar Roberto Bitencourt ${ }^{118}$ afirma que a culpabilidade refere-se à possibilidade de aplicação de uma pena ao autor de um fato descrito como crime pela lei penal e, para tanto, exige-se alguns requisitos, quais sejam estes: a capacidade de culpabilidade, consciência da ilicitude e exigibilidade da conduta, os quais constituem os elementos positivos específicos do conceito dogmático de culpabilidade e a ausência de qualquer um desses elementos se faz suficiente para impedir a aplicação de uma sanção penal.

Devido à importância deste princípio com o tema central do presente trabalho, cumpre analisar, ainda que de maneira breve, a culpabilidade enquanto elemento do crime.

\subsubsection{2 - A culpabilidade como elemento do crime}

A culpabilidade, juntamente com a ilicitude e a antijuridicidade, fundamenta a imposição de uma pena por constituir um dos elementos do crime, segundo o conceito analítico. Assim sendo, não basta dizer que o crime é fato típico e antijurídico, é imprescindível que a conduta do agente seja culpável para que possa incidir a sanção penal do ato criminoso.

Pela noção do elemento culpabilidade, se atribui ao agir humano uma característica que o torna reprovável e, por consequência, punível. Realizado este juízo de reprovação penal da conduta delituosa e verificado que, no caso concreto, estão presentes os elementos da culpabilidade, torna-se possível, como dito acima, responsabilizar o agente pelo cometimento do crime.

\footnotetext{
${ }^{118}$ BITENCOURT, Cezar Roberto. Op.cit., p. 16.
} 
Antes da Reforma Penal de 1984, o Direito Penal se pautava pelos ditames da teoria causalista da ação. Segundo Ney Moura Teles, "este era o Direito Penal do resultado, da responsabilidade objetiva, que predominava entre os povos bárbaros e no direito romano primitivo" 119.

Neste momento histórico predominava a 'culpabilidade de autor', ou seja, a noção de culpabilidade atrelava-se à pessoa do autor do fato e se esgotava em uma relação interna deste frente à ação. Os elementos 'dolo' e 'culpa' constituíam a culpabilidade e a imputabilidade se fazia pressuposto desta, ou seja, a pena se associa de modo imediato à periculosidade do autor, que a justifica ${ }^{120}$.

A culpabilidade era vista aqui sob um aspecto puramente naturalístico ou psicológico, ou seja, desprovida de qualquer valoração e se esgota na simples constatação da posição do agente perante sua própria conduta. É a chamada teoria psicológica da culpabilidade.

Acerca do sistema causal-naturalista, Juarez Tavares informa que "fazendo-se da causalidade objetiva e do liame subjetivo partes constitutivas essenciais do delito, dissociase sua análise, consequentemente, em dois estágios legais, de maneira que a primeira (causalidade) se encontra caracterizada na tipicidade e na antijuridicidade, e a última parte (vínculo psicológico) constitui a base da culpabilidade" ${ }^{121}$.

Para a teoria psicológica da culpabilidade, que se baseava nas premissas positivistas do século XIX, a culpabilidade correspondia à culpa em sentido amplo, ao nexo subjetivo que liga o delito ao autor e como se relacionava com o aspecto psicológico do delito, com o ímpeto interno da pessoa do delinquente, nela se concentravam o dolo e a culpa ${ }^{122}$.

O problema dessa conceituação relacionou-se precipuamente em relação às situações em que o autor do fato agia culposamente, sem vontade alguma de cometer o crime, pois, se não havia vontade, não se podia falar em caráter psicológico ${ }^{123}$.

Tal concepção acerca da culpabilidade acabou por superada pela teoria normativa (ou psicológico normativa), a qual teve seu surgimento no século XX sob a influência do neoclassismo e passou concebê-la como reprovabilidade, sem, no entanto, afastar-lhe o dolo e

\footnotetext{
119 TELES, Ney Moura. Direito Penal: parte geral. São Paulo: Editora de Direito, 1996, p. 351.

${ }^{120}$ JESCHECK, Hans-Heinrich; WEIGEND, Thomas. Tratado de derecho penal: parte general. Traducción de Miguel Olmedo Cardenete. 5. ed. Granada: Comares, 2002, p. 58.

${ }^{121}$ TAVARES, Juarez. Teorias do delito (variações e tendências). São Paulo: Revista dos Tribunais, 1980, p. 20.

${ }^{122}$ BASILEU GARCIA. Instituições de direito penal. São Paulo: Max Limonad, 1970, p. 247-248.

${ }^{123}$ BITENCOURT, Cezar Roberto. Op.cit., p. 288.
} 
a culpa. Reinhard Frank, que foi o fundador desta teoria, explicava que a culpabilidade era composta de uma relação psicológica e também de um juízo de reprovação ${ }^{124}$.

Aníbal Bruno ${ }^{125}$, adepto da teoria psicológico-normativa da culpabilidade, lecionou no sentido de que se faziam presentes dois aspectos na culpabilidade: o aspecto puramente psicológico consistente na representação da vontade do fato e o aspecto normativo que corresponderia à representação do caráter ilícito do fato e vontade ilícita, e dessa forma se estabeleceria a relação psicológico normativa.

Miguel Reale Junior esclarece que a teoria normativa visou estabelecer um juízo de reprovação, referindo a vontade do agente à vontade da lei, valorando o comportamento concretamente individualizado e situado, porque a culpabilidade psicológica não respondia ao imperativo de individualização e eticização da responsabilidade ${ }^{126}$.

Com essa nova teoria, passou-se a entender que o dolo e a culpa eram elementos da culpabilidade, porém de conteúdo insuficiente para serem considerados como modalidade dela. Assim, teve-se por mais plausível considerar que o fato somente é censurável se, nas circunstancias em que tivesse ocorrido, fosse possível exigir do agente um comportamento diverso, em consonância com o direito.

Desse modo, o dolo e a culpa, enquanto liames psicológicos entre o autor e o fato, são valorados normativamente; assim, deve-se fazer um juízo de censura sobre a conduta e aquela somente será ilícita se, nas circunstâncias, se pudesse exigir do agente um comportamento de acordo com o direito, incidindo aí a reprovabilidade.

Entretanto, esta teoria também se revelou insuficiente a abarcar toda a complexidade da questão, pois, ao passo que resolvia o problema da teoria anterior, despontava um novo, qual seja o "dolo híbrido" (composto do elemento psicológico - vontade - e do elemento normativo - consciência da ilicitude) que não conseguia resolver, por exemplo, a questão da punibilidade do criminoso habitual (criminoso por tendência), uma vez que este não possuía a consciência da ilicitude em face de ter sido criado em um ambiente no qual as condutas ilícitas eram cotidianas ${ }^{127}$.

A teoria normativa pura da culpabilidade surgiu, então, como forma de refutar as anteriores, a teoria psicológica e a teoria psicológico-normativa da culpabilidade, as quais fincavam suas bases, respectivamente, na teoria da ação causal e no neokantismo.

\footnotetext{
${ }^{124}$ FRANK, Reinhard. Apud BITENCOURT, Cezar Roberto. Op.cit., p. 290.

${ }^{125}$ FIRMO, Aníbal Bruno de Oliveira. Direito penal, parte geral, tomo II: fato punível. Rio de Janeiro: Forense, 2003, p. 37-38.

${ }^{126}$ REALE JÚNIOR, Miguel. Instituições de direito penal. 3. ed. Rio de Janeiro: Forense, 2009, p. 177.

${ }^{127}$ BITENCOURT, Cezar Roberto. Op.cit., p. 293.
} 
Hans Welzel ${ }^{128}$ readequou sistematicamente os elementos do crime e propiciou evolução na dogmática do direito penal, quando separou definitivamente as peculiaridades subjetivas, ou seja, aquelas intrínsecas à pessoa do delinquente, das peculiaridades valorativas, estas sim que constituem o juízo de reprovação da conduta criminosa, ou seja, o precursor da teoria finalista da ação não formulou requisitos novos para integrar a dogmática do crime, nem eliminou os que neokantismo já havia identificado, mas apenas reordenou a posição sistemática dos mesmos.

A partir de então, tornou-se possível dizer que a culpabilidade se insere no sistema finalista do delito, o qual trabalha com as estruturas ontológicas (lógico-reais), tendo a vontade como característica fundamental da ação dirigida a uma finalidade. Esta, nos crimes dolosos, vem expressa no próprio tipo penal que abrange a ação final em si, ao passo que, nos delitos culposos, o tipo penal cuida do modo de execução da ação final frente a consequências sociais não incluídas na vontade do agente ${ }^{129}$.

Assim, foram retirados os elementos anímicos subjetivos, o dolo e a culpa, dos elementos que constituem o juízo de reprovação, passando, então, pertencerem à conduta.

Em verdade, o que ocorreu foi o que Nivaldo Brunoni chama de subjetivação do tipo e de normatização da culpabilidade, sintetizando que a reprovação ocorre em razão da inobservância do dever de se omitir da prática ilícita ${ }^{130}$.

Segundo Hans Welzel, a culpabilidade é o que permite reprovar o autor, quando este tinha a aptidão de atuar conforme as normas e a comunidade jurídica, e adotou conduta contrária ao Direito; corresponde a um juízo de valor negativo sobre a conduta ilícita, o que a torna um conceito graduável, ou seja, a culpabilidade pode ser maior ou menor, de acordo com a importância que tenha a exigência do Direito e com a facilidade ou dificuldade do autor em satisfazê-la ${ }^{131}$.

De acordo com essa perspectiva, excluem-se do conceito de culpabilidade os elementos subjetivos, anímicos ou psicológicos, que passam a integrar do tipo de injusto, conservando-se apenas o critério da censurabilidade ou reprovabilidade como elemento

\footnotetext{
${ }^{128}$ WELZEL, Hans. O novo sistema jurídico-penal: uma introdução à doutrina da ação finalista. Tradução de Luiz Regis Prado. 2. ed. São Paulo: Revista dos Tribunais, 2009, p. 95.

${ }^{129}$ LOBATO, José Danilo Tavares. Da evolução dogmática da culpabilidade. In: GRECO, Luís; LOBATO, Danilo (org.). Temas de direito penal - parte geral. Rio de Janeiro: Renovar, 2008, p. 308.

${ }^{130}$ BRUNONI, Nivaldo. Princípio da culpabilidade: considerações, fundamentos, teorias e consequências. Curitiba: Juruá, 2008, p.148.

${ }^{131}$ WELZEL, Hans. Op.cit., p. 96.
} 
valorativo. Tal juízo de reprovação se constitui da imputabilidade, a consciência da ilicitude e a exigibilidade de conduta diversa ${ }^{132}$.

O Código Penal brasileiro, com a reforma da parte geral ocorrida no ano de 1984, adota como regra a teoria limitada da culpabilidade, também fundamentada na teoria finalista da ação, a qual se constitui numa modalidade da teoria normativa pura da culpabilidade, assim como a teoria estrita da culpabilidade, diferenciando-se desta última em relação ao instituto do erro sobre os pressupostos fáticos, conforme lembra Luiz Regis Prado ao elucidar que a diferença entre as teorias estrita e limitada da culpabilidade está no tratamento dado ao erro sobre os pressupostos fáticos de uma causa de justificação que, para a teoria estrita, chamava-se erro de proibição; para a teoria limitada (erro de tipo permissivo) ${ }^{133}$.

Tais diferenciações, contudo, não serão analisadas, devido ao fato de não possuírem pertinência com o tema central deste trabalho, sendo importante destacar somente a adoção da referida teoria pelo ordenamento jurídico brasileiro atual, conforme se depreende das palavras de Miguel Reale Júnior:

"Dúvida surge acerca da posição adotada em nosso Código por força da Reforma de 1984. A Exposição de Motivos deixa claro que se adotou a teoria limitada. E parece-me ser esta efetivamente a orientação seguida, pois o dispositivo da descriminante putativa constitui um parágrafo do art. 20, relativo ao erro de tipo. Se o erro é vencível ou evitável, art. 20, $\$ 1^{o}$, não há isenção de pena, se o fato é punível como crime culposo. Se o erro de proibição, sobre a ilicitude do fato, for inevitável, há isenção de pena, art. 21; mas se evitável, a pena poderá ser diminuída de um sexto a um terço, parte final do art. 21 do Código Penal. Assim, a meu ver, efetivamente, o Código Penal adota a solução prognosticada pela teoria limitada, tratando diferentemente o erro de tipo permissivo e o erro de permissão. E o art. 21, parágrafo único, esclarece quando é o erro evitável, ou seja, quando era possível ao agente atingir, nas circunstâncias, a consciência da ilicitude ${ }^{134, "}$.

Das considerações expostas neste tópico do presente trabalho, vislumbra-se que, com a consolidação da teoria finalista ou teoria normativa pura da culpabilidade, houve atenção do Direito Penal no sentido de tentar prever todas as possibilidades de configuração da

\footnotetext{
${ }^{132}$ PRADO, Luiz Régis. Op.cit., p. 345 - 346.

${ }^{133}$ Idem, p. 360.

${ }^{134}$ REALE JUNIOR, Miguel. Op.cit., p. 202.
} 
culpabilidade, procurando delimitar a abrangência de seu alcance para o plano valorativo, atentando-se ainda para as diversas situações em que a pessoa age sem que se possa emitir um juízo reprovável sobre o fato.

\subsubsection{3 - A culpabilidade como limite da aplicação da pena}

Crime é o conjunto de todos os requisitos gerais indispensáveis para que possa ser aplicável a sanção penal. Tais requisitos são a conduta típica, antijurídica e culpável ${ }^{135}$.

Esses diferentes elementos do crime estão numa relação lógica necessária, de forma que somente uma ação ou omissão pode ser típica, somente uma ação ou omissão típica pode ser antijurídica e somente uma ação ou omissão antijurídica pode ser culpável ${ }^{136}$.

A culpabilidade não só fundamenta a pena, mas a limita, ou seja, serve de parâmetro que referencia a individualização da sanção penal.

É a culpabilidade que viabiliza a condenação, que enseja a escolha da pena quando há alternativa, bem como a sua quantificação, revelando-se, assim, base fundamental para a individualização da pena ${ }^{137}$.

E ao mesmo tempo em que é uma condição para a punibilidade, a culpabilidade também se faz um critério para a determinação da pena. É nesse duplo significado que se fala da culpabilidade como um princípio $^{138}$.

Guilherme de Souza Nucci escreve que o termo culpabilidade substitui as antigas expressões "intensidade do dolo" e "graus da culpa", que eram previstas dentre as circunstâncias judiciais. No Direito Penal atualmente vigente no Brasil, ao analisar a tipicidade do fato, o juiz verifica se houve dolo ou culpa, não sendo necessário se preocupar se o dolo foi intenso ou não ou se a culpa foi grave ou não. Dessa forma, estabelece se houve crime doloso ou culposo e, em seguida, no momento da aplicação da pena, o elemento subjetivo do crime, inserido que está na tipicidade, não deve servir de guia para o juiz, pois, o que importa nesta fase é a reprovabilidade gerada pelo fato delituoso. Assim, sustenta-se que a culpabilidade prevista no artigo 59 do Código Penal é o conjunto de todos os demais fatores unidos ${ }^{139}$.

\footnotetext{
${ }^{135}$ FRAGOSO, Heleno Cláudio. Op. Cit. p. 198.

${ }^{136}$ CEREZO MIR, José. Apud BITENCOURT, Cezar Roberto. Op.cit., p. 107.

${ }^{137}$ LUISI, Luiz. Op.cit., p. 37.

${ }^{138}$ JESCHECK, Hans-Heinrich. Apud COSTA, Pedro Jorge. Relações entre pena concreta e culpabilidade no direito brasileiro. Revista Forense, vol. 410, jul-ago 2010, p. 233.

${ }^{139}$ NUCCI, Guilherme de Souza. Individualização da pena. 3 ed. ver. atual e ampl. São Paulo: Revista dos Tribunais, 2009, p. 173 e 174.
} 
Em cada tipo penal o legislador previu abstratamente um parâmetro de possibilidade de aplicação da pena, pela determinação do juízo de reprovabilidade da conduta delituosa.

Nessa previsão abstrata da pena para cada crime, o legislador estabeleceu limites para pautar o julgador e, apenas com a devida análise no caso específico e consequente individualização, a pena passará a ser concreta, ou seja, fixada em definitivo. E, para determinar a pena, o juiz obedece ao método trifásico, positivado no artigo $68^{140}$ do Código Penal.

O método trifásico possibilita que o condenado fique ciente do procedimento que o juiz está seguindo para a obtenção da pena em concreto, uma vez que este deve fundamentar sua conclusão e sua decisão ${ }^{141}$, utilizando-se do raciocínio lógico-dedutivo a fim de individualizar a sanção cabível conforme determina a Constituição Federal ${ }^{142}$.

O artigo 59 do Código Penal ${ }^{143}$ fornece elementos que o julgador precisa avaliar para a fixação da pena base; na lição de Eugenio Raul Zaffaroni e José Henrique Pierangeli, tais elementos exigem uma ordenação sistemática "porque não se trata de uma síntese ordenada, mas de elementos um tanto dispersos e cuja ordem hierárquica se faz necessário determinar" 144 .

As circunstâncias judiciais classificam-se em subjetivas e objetivas. Estas abarcam as circunstâncias e consequências do crime e o comportamento da vítima, enquanto aquelas compreendem a culpabilidade, os antecedentes, a conduta social, a personalidade e os $\operatorname{motivos}^{145}$.

\footnotetext{
${ }^{140}$ Artigo 68 do Código Penal brasileiro. A pena-base será fixada atendendo-se ao critério do art. 59 deste Código; em seguida serão consideradas as circunstâncias atenuantes e agravantes; por último, as causas de diminuição e de aumento.

${ }^{141}$ Art. 93, IX da Constituição da República Federativa do Brasil, 1988 - todos os julgamentos dos órgãos do Poder Judiciário serão públicos, e fundamentadas todas as decisões, sob pena de nulidade, podendo a lei limitar a presença, em determinados atos, às próprias partes e a seus advogados, ou somente a estes, em casos nos quais a preservação do direito à intimidade do interessado no sigilo não prejudique o interesse público à informação.

${ }^{142}$ NUCCI, Guilherme de Souza.Op.cit., p. 166.

${ }^{143}$ BRASIL. CÓDIGO PENAL. Art. 59. O juiz, atendendo à culpabilidade, aos antecedentes, à conduta social, à personalidade do agente, aos motivos, às circunstâncias e consequiências do crime, bem como ao comportamento da vítima, estabelecerá conforme seja necessário e suficiente para reprovação e prevenção do crime:

I- as penas aplicáveis dentre as cominadas;

II- a quantidade de pena aplicável, dentro dos limites previstos;

III- o regime inicial de cumprimento da pena privativa de liberdade;

IV- a substituição da pena privativa de liberdade aplicada, por outra espécie de pena, se cabível.

${ }^{144}$ ZAFFARONI, Eugenio Raúl e PIERANGELI, José Henrique. Manual de direito penal brasileiro. 7.ed. rev. e atual. São Paulo: Revista dos Tribunais, 2008, p. 709.

${ }^{145}$ BOSCHI, José Antonio Paganella. Das penas e seus critérios de aplicação. 4 ed. Porto Alegre: Livraria do Advogado, 2006, p. 187.
} 
Na obra de Eugenio Raul Zaffaroni e José Henrique Pierangeli enfatiza-se que a regra contida no artigo 59 do Código Penal de que o julgador deve se pautar com base no "necessário e suficiente para reprovação e prevenção do crime" e disso se entende que os elementos do artigo que vêm antes de referida expressão devem ser considerados para a determinação do grau de reprovação do injusto; assim, a medida da pena base indica o grau de culpabilidade ${ }^{146}$.

$\mathrm{Na}$ ótica deste autor, a culpabilidade, o primeiro dos elementos que aparece no texto legal mencionado, pode abarcar outros elementos tais como a motivação do delito, as circunstâncias e consequências do fato, além da personalidade do agente, no que tange a capacidade de autodeterminação deste, e ainda o comportamento da vítima que, ao passo que pode aumentar ou diminuir o injusto, também aumenta ou diminui a culpabilidade do sujeito ativo ${ }^{147}$.

Segundo Salo de Carvalho ${ }^{148}$, trata-se a culpabilidade de um juízo de reprovação do ato e não da personalidade do sujeito, reprovação do que o homem fez e não do que o homem é; ou, segundo Luiz Regis Prado ${ }^{149}$, juízo de valor que deve ser dirigido ao agente por, naquela ocasião específica, não ter agido de acordo com a norma, denotando seu caráter eminentemente deontológico.

Pela análise da culpabilidade se determina o quão reprovável do agente foi o fato praticado pelo agente; para tanto, o juiz considera o delito como um todo, não apenas as condições pessoais do infrator, ou seja, analisa-se a conduta que lhe era exigível naquela situação fática específica.

Porém, de acordo com o texto legal do artigo 59 do Código Penal, não tem como o juiz deixar de ao se analisar algumas condições pessoais do acusado tais como seu grau de instrução e de cultura, sua condição social, a vida pregressa e o meio em que vive, sem, no entanto, desprender-se do direito penal do fato; esta análise se faz imperiosa porque é sobre a pessoa do delinquente que a pena incidirá.

A análise da culpabilidade, que ocorre nas três etapas da fixação da pena, há de ser realizada com cuidado pelo juiz, uma vez que não se pode valorar o sujeito além do fato, ou seja, o juízo de censura deve estar atrelado estritamente ao crime, sob pena de se punir a pessoa por razões alheias da que está "sub judice" e, assim, configurar-se um direito penal de autor.

\footnotetext{
${ }^{146}$ ZAFFARONI, Eugenio Raúl e PIERANGELI, José Henrique Op.cit., p. 709-710.

147 Idem, p. 710.

${ }^{148}$ CARVALHO, Salo de. Aplicação da pena e garantismo. Rio de Janeiro: Lumen Juris, 2008, p. 46.

${ }^{149}$ PRADO, Luiz Régis. Op.cit., p. 420-421.
} 
Para reprovar a conduta do autor de um delito, há de observar se estão presentes os elementos constitutivos do conceito dogmático de culpabilidade, ou seja, exige-se que a pessoa tenha tido a possibilidade de compreender a antijuridicidade de sua conduta e que tenha atuado dentro de certo âmbito de autodeterminação mais ou menos amplo ${ }^{150}$.

Na lição de Jaime Náquira Rivero se enaltece a necessidade de se conhecer o meio no qual o indivíduo viveu e cresceu, a educação que recebeu e a que teve acesso por suas condições socioeconômicas, a forma como se insere e participa do grupo social de que participa, para valorar quão reprovável é sua conduta ${ }^{151} \mathrm{e}$, assim, formar-se o juízo de culpabilidade.

Diante disso, insta trazer também a lição de Juarez Cirino dos $\operatorname{Santos}^{152}$, que frisa a necessidade da correta avaliação da culpabilidade, desdobrando em seu conceito. Primeiramente, a adjetivação da conduta como delituosa, vinculando-a a um sujeito, quando presentes os pressupostos da culpabilidade enquanto elemento constitutivo do crime, quais sejam, imputabilidade (capacidade geral ou abstrata de compreender o valor do fato e de querer conforme a compreensão do valor do fato, excluída ou reduzida em situações de imperfeição (imaturidade) ou de defecção (doença mental) do aparelho psíquico); consciência da antijuridicidade (conhecimento concreto do valor que permite ao autor imputável saber, realmente, o que faz excluída ou reduzida em casos de erro de proibição); e exigibilidade de conduta diversa (expressão de normalidade das circunstâncias do fato e indicação de que o autor tinha o poder de não fazer o que fez).

Ademais, a culpabilidade também é um elemento limitador do poder punitivo na aplicação da pena. O mesmo autor afirma que, com a troca de uma função metafísica de legitimação da punição por uma função política de garantia da liberdade individual, a tese da culpabilidade como fundamento da pena foi substituída pela tese da culpabilidade como limitação do poder de punir $^{153}$.

Tanto é assim que o próprio ordenamento jurídico prevê hipóteses em que a responsabilidade penal do agente pode ser excluída ou reduzida, conforme o caso, de acordo com a constatação da presença de alguma causa exculpante ou de redução de culpabilidade, isso confirma a noção de que a culpabilidade é pressuposto da existência da responsabilidade penal.

\footnotetext{
${ }^{150}$ ZAFFARONI, Eugenio Raul e PIERANGELI, José Henrique. Op.cit., p. 521.

${ }^{151}$ RIVEROS, Jaime Náquira. Imputabilidad, conciencia de lo injusto y contexto situacional normal: De sú objeto, contenido e relación. Doctrina Penal - Teoría y Práctica em las Ciencias Penales, año 12, nº 45 a 48. Buenos Aires: Ediciones Delpalma, 1989, p. 49.

${ }^{152}$ SANTOS, Juarez Cirino dos. A moderna teoria do fato punível. Curitiba: Lumen Juris, 2005, p. 199-202.

${ }^{153}$ Idem, p. 205.
} 
Desta função da culpabilidade, Salo de Carvalho entende que é daí que parte a ideia e a necessidade de aperfeiçoar a estrutura garantista do direito penal, comprometendo-se o jurista com o modelo político-criminal minimalista e sendo detentor da obrigação de reduzir ao máximo os espaços de discricionariedade e a violência institucional ${ }^{154}$.

\subsubsection{4 - Elementos da Culpabilidade}

A culpabilidade, se considerada como reprovabilidade pessoal do autor do delito, é ainda vista como um conceito formal, que não determina qual será especificamente o fundamento da reprovação ${ }^{155}$.

No entendimento de Luiz Regis Prado, tem-se que o conceito material de culpabilidade deve ser coerente com o conceito de ser humano que inspira o texto constitucional. A Carta brasileira se funda na concepção do homem como pessoa, como ser responsável, capaz de autodeterminação segundo critérios normativos ${ }^{156}$.

Como já mencionado, o conceito de culpabilidade comporta o aspecto social e jurídico, sendo construído de acordo com os requisitos da vida social do indivíduo e dependendo, muitas vezes, da situação socioeconômica em que ele está inserido, atrelado às mínimas exigências da sociedade e da época em que se encontra. Se a sociedade passa por transformações, o conteúdo da culpabilidade também será alterado, por isso se toma por parâmetro "a medida do juízo de culpabilidade" 157.

É através do juízo de culpabilidade que se examina a reprovação do indivíduo que não haja observado as exigências gerais ${ }^{158}$, ou seja, a culpabilidade é estrutura relacionada à reprovabilidade, no sentido de juízo de censura sobre a conduta do sujeito que, livre para agir, poderia e deveria ter agido de acordo com o Direito; que poderia ter sido motivado pela norma e não afrontar o ordenamento.

Sendo o sistema jurídico um sistema aberto devido à sua capacidade de evolução e de modificação, ou seja, um sistema que se encontra em permanente mudança e aperfeiçoamento e, dessa forma, fica atento ao processo evolutivo da sociedade, o Direito Penal também não é uma construção isolada no tempo, mas é produto de um longo

\footnotetext{
${ }^{154}$ CARVALHO, Salo de. Op.cit., p. 47.

${ }^{155}$ CEREZO MIR, José. El concepto material de culpabilidad. Criminalia. Academia Mexicana de Ciencias Penales, Año LXIII, n. 2. México, D.F: Mayo-Ago, 1997, p. 25.

${ }^{156}$ PRADO, Luiz Regis. Op.cit., p. 438.

${ }^{157}$ BAUMANN, Jürgen. Culpabilidad y Expiación. Nuevo Pensamiente Penal. Revista Cuatrimestral de Derecho Y Ciencias Penales. Fundada por Luis Jiménez de Asúa. Año 1, nº 1, Enero-abril 1972, p. 28.

${ }^{158}$ REALE JÚNIOR, Miguel. Teoria do Delito. São Paulo: Editora Revista dos Tribunais, 1998, p. 145.
} 
caminho histórico, que deriva da constante evolução das instituições penais e em seu próprio conteúdo apresenta elementos ensejadores de potenciais transformações futuras ${ }^{159}$.

Por isso, hoje se tem um Direito Penal calcado na culpabilidade, conforme já se mencionou anteriormente ao se expor a evolução do conceito de culpabilidade e afirma-se que a culpabilidade, entendida como juízo de reprovação, também é dependente do momento político, social e até cultural que um determinado Estado vive.

Cezar Roberto Bitencourt cita a lição de Von Liszt no sentido de que o progresso do Direito Penal é medido pelo aperfeiçoamento da teoria da culpabilidade ${ }^{160}$.

Para que uma conduta seja considerada reprovável, seu agente deve possuir a chamada 'capacidade de culpabilidade', isso quer dizer que, quem cometeu o delito tem de estar apto a receber a sanção penal; para tanto, é necessário que o autor do fato, no momento que praticou a conduta criminosa, tivesse a possibilidade de entender o caráter ilícito da conduta que pretendia adotar e de nortear seu comportamento em conformidade com a norma.

Segundo Ney Moura Teles, “culpável, portanto, é o fato praticado por um sujeito imputável que tinha possibilidade de saber que seu comportamento era proibido pelo ordenamento jurídico, e que, nas circunstâncias em que agiu, poderia ter agido de modo diferente, conforme o direito" 161 .

Cumpre analisar, ainda que de maneira breve, os elementos que constituem a culpabilidade, esta enquanto elemento do crime.

O primeiro deles é a imputabilidade. Imputar significa atribuir responsabilidade.

Na doutrina de Heleno Cláudio Fragoso, “imputabilidade é a condição pessoal de maturidade e sanidade mental que confere ao agente a capacidade de entender o caráter ilícito do fato ou de se determinar segundo esse entendimento ${ }^{162, "}$

O Código Penal Brasileiro, em seus artigos 26, “caput” e 28, parágrafo primeiro, prevê expressamente quatro causas que excluem a imputabilidade de uma pessoa e, por consequência, excluem a culpabilidade do fato por ela praticado, quais sejam a doença mental; o desenvolvimento mental incompleto; o desenvolvimento mental retardado; e a embriaguez completa, proveniente de caso fortuito ou força maior.

\footnotetext{
${ }^{159}$ CANARIS, Claus-Wilhelm. Pensamento sistemático e conceito de sistema na ciência do direito. Trad. António Menezes Cordeiro. Lisboa: Fundação Calouste Gulbenkian, 1996, p. 102 a 126.

${ }^{160}$ LISZT, Franz Ritter von Apud BITENCOURT, Cezar Roberto. Op. Cit. p. 116.

161 TELES, Ney Moura. Op. Cit., p. 358.

${ }^{162}$ FRAGOSO, Heleno Cláudio. Op.cit., p. 197.
} 
A pessoa que não possui capacidade para compreender o caráter ilícito do fato, isto em razão de doença mental ou desenvolvimento mental incompleto ou retardado, ou até mesmo de uma embriaguez completa proveniente de caso fortuito ou força maior, não pode ser responsabilizada criminalmente e ver contra si aplicada uma pena por lhe faltar o caráter de imputável.

Essa conceituação de imputabilidade adveio do chamado sistema biopsicológico ${ }^{163}$ que consiste em se verificar, primeiramente, se o agente apresenta algum tipo de doença mental ou alguma mácula em seu desenvolvimento mental que o torne incompleto ou retardado.

Em caso negativo, tem-se que a pessoa é imputável, mas, em caso positivo, se analisará se o indivíduo era, no tempo do delito, capaz de entender o caráter ilícito do fato; se tiver essa capacidade, será imputável. A inimputabilidade, por conseguinte, decorre da conjugação desses dois critérios.

O Código Penal brasileiro prevê também a possibilidade de o sujeito ser semiimputável, o que ocorre quando, por doença mental ou desenvolvimento mental incompleto ou retardado há a perda parcial da capacidade de compreensão da ilicitude do fato ou de portar-se de acordo com a norma.

Nesta situação, não se afasta a imputabilidade, nem tampouco será afastada a culpabilidade, mas o que o parágrafo único do artigo 26 do Código Penal dispõe é que a pena a ser aplicado ao indivíduo semi-imputável seja reduzida ${ }^{164}$.

Contudo, para que se vislumbre a culpabilidade, além de o agente ser imputável, se faz necessário que o sujeito tenha consciência, ainda que potencial, da ilicitude do fato e que se possa exigir dele a obediência ao ordenamento jurídico.

Assim, após verificar que o indivíduo é imputável, há de se apurar se, no momento do cometimento do fato criminoso concreto, ele poderia compreender a ilicitude de seu comportamento.

\footnotetext{
${ }^{163}$ Atingiu-se esse sistema biopsicológico pela conjugação das ideias de dois sistemas preexistentes, o sistema biológico, no qual aquele que apresenta uma anomalia psíquica seria considerado sempre inimputável, e o sistema psicológico, no qual se verificam apenas as condições psíquicas do sujeito no momento do cometimento do crime, afastando-se qualquer hipótese de verificação da presença de doenças mentais ou distúrbio psíquico patológico. O primeiro sistema revelou-se insuficiente por deixar impune aquele que, embora sendo portador de alguma doença mental ou possuir desenvolvimento mental incompleto, ainda tem discernimento e capacidade de determinação e o segundo sistema revelou-se inviável por ser de difícil averiguação e dotado de baixa cientificidade. Nesse sentido: NORONHA, E. de Magalhães. Direito penal. 30 ed. São Paulo: Saraiva, 1995.

${ }^{164}$ Artigo 26 parágrafo único do Código Penal brasileiro. A pena pode ser reduzida de um a dois terços, se o agente, em virtude de perturbação de saúde mental ou por desenvolvimento mental incompleto ou retardado não era inteiramente capaz de entender o caráter ilícito do fato ou de determinar-se de acordo com esse entendimento.
} 
O potencial conhecimento da ilicitude do fato corresponde à capacidade de o agente vir saber que sua conduta tinha um caráter contrário ao direito ${ }^{165}$.

Esse segundo aspecto que se examina na análise da culpabilidade, assim como o primeiro elemento (imputabilidade), fundamenta a censura penal, pois se não for possível que o agente atinja a consciência do caráter ilícito que reveste sua conduta, logo, não é possível censurar a finalidade manifestada na conduta socialmente inadequada ${ }^{166}$.

Isso implica que o sujeito não precisa saber que sua conduta está prevista em um tipo penal, mas o que basta é se nas condições em que ele vive tem como saber se aquele comportamento é contrário ao direito, ou seja, se aquela pessoa teve, no momento do cometimento do fato, condições para saber que aquilo era discrepante com o ordenamento.

O terceiro elemento que se analisa para verificar se está presente a culpabilidade é a exigibilidade de obediência ao Direito ou de conduta diversa, que consiste na aferição de se era possível exigir que o indivíduo, nas condições que cometeu o crime, adotasse uma conduta diversa da conduta criminosa e que obedecesse ao Direito, respeitando o ordenamento jurídico.

René Ariel Dotti ${ }^{167}$ afirma que para ser possível ter uma ação o caráter de culpável não basta que o seu autor tenha previsto e querido certo evento lesivo, mas é preciso também que sua vontade fosse apta a se determinar normalmente à ação e essa determinação normal não pode ser exigida quando as condições de fato em que o indivíduo atua são de molde a tornar impossível ou muito menos difícil a formação de um querer imune de defeitos.

Da lição de referido autor também se depreende que o requisito da exigibilidade de conduta diversa ou de obediência ao direito pode ser definido como a possibilidade que o indivíduo infrator tinha de agir, no momento do fato, segundo os parâmetros de conduta impostos pelo ordenamento jurídico, ou seja, por ser capaz e ter consciência, ainda que potencial, da ilicitude, deveria ter atuado de maneira diversa da criminosa ${ }^{168}$.

Nota-se que a ausência de um desses requisitos impede a decretação do juízo de reprovação do fato; são os casos em que se configura a inimputabilidade, a inexigibilidade de conduta diversa ou a não possibilidade de atingir a consciência da ilicitude do ato, isto porque, são esses elementos que integram o atual conceito de culpabilidade a fundamentam.

\footnotetext{
${ }^{165}$ SANTOS, Juarez Cirino dos. Op.cit., p. 202.

${ }^{166}$ ZAFFARONI, Eugenio Raúl e PIERANGELI, José Henrique. Op.cit., p. 534.

${ }^{167}$ DOTTI, Rene Ariel. Op. cit., p. 349.

${ }^{168}$ Idem.
} 
Embora a o juízo de reprovação incida sobre o sujeito que praticou o ato porque é ele que vai sofrer a pena, o Direito Penal que deve vigorar em um Estado Democrático de Direito para que corresponda aos interesses da sociedade é aquele que se assenta sobre o fato praticado pelo agente e não sobre o agente do fato, é o já mencionado Direito Penal do Fato, no qual se analisa a Culpabilidade do Fato.

\subsubsection{5 - Culpabilidade funcional: conceito e críticas}

Após a concepção finalista, que é adotada pelo Código Penal brasileiro, surgiu na Alemanha o movimento funcionalista, apoiado em medidas políticos-criminais prevencionistas, pelo que atribuiu uma nova ótica para o conteúdo do Direito Penal, mais especificamente, pugnando pela transição científico-dogmática para uma política criminal empírica e com foco voltado mais ao limite da pena do que com sua legitimação ${ }^{169}$.

Winfried Hassemer analisa o conceito de culpabilidade tanto sob a ótica finalista, quanto sob a ótica funcionalista e se manifesta no sentido da dificuldade de se extrair referido conceito, haja vista, entendendo-o como reprovação, omite-se os fatores externos que levam uma pessoa à consecução de um delito, o que remete à noção de que a culpabilidade pode ser definida como a ausência de causas de exclusão da culpabilidade ${ }^{170}$.

Segundo Claus Roxin, mesmo ante os diversos aspectos em que pode ser estudada pelas diversas ciências que dela se ocupam, a culpabilidade, para a dogmática penal, deve servir unicamente para determinar em que medida uma pessoa pode ser responsabilizada pela prática de um ato socialmente lesivo e, assim sendo, o princípio da culpabilidade não deve ser analisado isoladamente, mas em conjunto com outros princípios de Direito Penal $^{171}$.

Este autor analisa o princípio da culpabilidade sob a ótica da imputação subjetiva e também da imputação objetiva. Estudando a exclusão do acaso, que chama de aspecto externo do princípio culpabilidade, Claus Roxin considera que esta se efetiva através da teoria da imputação objetiva, haja vista, somente será possível se imputar a alguém um determinado curso causal quando este revelar a criação de um risco não permitido por parte do agente. Se o resultado lesivo ao bem jurídico não puder ser atribuído ao sujeito, mas o for ao acaso, isenta-se a pessoa da responsabilidade ${ }^{172}$.

\footnotetext{
${ }^{169}$ HASSEMER, Winfried. Introdução aos fundamentos do direito penal. Porto Alegre: Safe, 2005, p. 303.

${ }^{170}$ Idem, p. 322.

${ }^{171}$ ROXIN, Claus. Op.cit. p. 134.

${ }^{172}$ Idem, p. 136.
} 
Isso significa que apenas quando o resultado ocorrer devido à criação por alguém de um risco não permitido é que se excluirá o acaso, vislumbrando-se, então, o aspecto externo do princípio da culpabilidade.

Contudo, a teoria da imputação objetiva abrange, em sua estruturação sistemática, outros princípios além do princípio da culpabilidade, por exemplo, o princípio da autonomia da vítima e o princípio da atribuição a um âmbito de responsabilidade de terceiros.

Para a imputação subjetiva devem concorrer a culpabilidade e a necessidade preventiva de pena, por isso que Claus Roxin chama de responsabilidade, e não de culpabilidade, a categoria que sucede ao injusto. A pena se justifica, então, pela concorrência da culpabilidade e da necessidade de prevenção, podendo ser dosada abaixo da medida da culpabilidade se as exigências da prevenção assim condicionarem sua aplicação $^{173}$.

Outro funcionalista que estudou a teoria do delito e trouxe conclusões um tanto impactantes foi Günther Jakobs. De acordo com seus estudos, se o delito for entendido como infração de um dever, para que seja possível garantir padrões cognitivos de comportamento, o Direito Penal precisa convertê-los em normas ${ }^{174}$.

Sua proposta é de que o Direito Penal deve garantir a vigência das normas e não propriamente a segurança dos bens jurídicos, pois a sociedade teria se constituído a partir da vigência da primeira norma e o conhecimento da norma equivale ao conhecimento da realidade social, ainda que o autor de um fato criminoso não aceite aquele norma como válida.

A conclusão de referido autor acerca da compreensão do delito se dá no sentido de que este ocorre como manifestação de um processo de comunicação defeituosa que se imputa ao autor como culpa sua. E a partir daí, tem-se a culpabilidade como a negação ao conteúdo da norma e considera que seu fundamento reside no juízo social objetivo da falta de fidelidade ao ordenamento jurídico e não em processos de natureza psíquica do autor do delito. Nesse sentido, uma vez que se constata que a conduta (comunicação) do autor é discrepante do conteúdo da norma e, portanto, destruidora das estruturas básicas do

\footnotetext{
${ }^{173}$ Idem, p. 155.

${ }^{174}$ JAKOBS, Günther. Conocimiento y desconocimiento de la norma. Problemas capitales del derecho penal moderno. Buenos Aires: Hammurabi, 1998, p. 57-63.
} 
ordenamento, deve aquela ser anulada, neutralizada, mediante a aplicação da pena, que terá por escopo restaurar a quebra da norma ${ }^{175}$.

Faz-se necessário que o autor da conduta delituosa possua competência, aptidão, capacidade para questionar a validade da norma, ou seja, deve ser imputável. Por isso, vislumbra-se que o conceito funcional de culpabilidade de Günther Jakobs não se refere a um sujeito concretamente determinado, movido por seus processos psíquicos, mas pode ser considerado um conceito instrumental, cuja ênfase se encerra no juízo social objetivo de falta de fidelidade ao ordenamento jurídico.

Alessandro Baratta, por sua vez, conclui que a teoria de Günther Jakobs nada mais pode ser considerada uma tentativa tecnocrática de proteger o sistema penal da profunda crise que enfrenta, por uma redefinição da fundamentação da pena, com o intuito de reproduzir ideológica e materialmente as relações sociais existentes ${ }^{176}$.

Tal teoria encontra-se imersa no contexto atual, uma vez que se faz cada vez mais frequente a defesa de um Direito Penal de maior eficácia, ainda que isto ocorra em detrimento de direitos e garantias individuais.

Segundo Enrique Bacigalupo Zapater, as exigências de prevenção podem estabelecer a aplicação da pena adequada para seus fins, mas esses fins não poderão ultrapassar os limites estabelecidos pela culpabilidade ${ }^{177}$.

Para ele, é pelo princípio da culpabilidade que se limita a quantidade legítima de pena a ser aplicada e se garante a indisponibilidade da dignidade humana.

Claus Roxin, menos radical que Günther Jakobs, manifesta discordância no que tange ao abandono da função restritiva da culpabilidade, entendendo que a necessidade preventiva da pena é subsidiária em relação ao princípio da culpabilidade, o qual continua em vigor pelo caráter limitativo que assume. Contudo, isso acaba por esvaziar referido princípio quanto à fundamentação da pena ${ }^{178}$.

Este autor acrescenta que a pretendida instrumentalização do indivíduo viola a dignidade humana e, por isso, torna-se incapaz de se fundamentar devidamente o conceito de culpabilidade. Para este autor, o maior descompasso da teoria de Jakobs é reduzir a

\footnotetext{
${ }^{175}$ Idem, p. 63.

${ }^{176}$ BARATTA, Alessandro. Integración-prevención: uma nueva fundamentacion de la pena dentro de la teoria sistêmica. Doctrina Penal - teoría y pratica en las ciencias penales, Buenos Aires: De Palma, n. 29 a 32, 1985, p.15 e 21.

${ }^{177}$ BACIGALUPO ZAPATER, Enrique. Derecho Penal Material y Estado Democrático de Derecho. Justicia Penal y Derechos Fundamentales, Madrid/Barcelona: Ed. Marcial Pons, 2002, p. 93.

${ }^{178}$ ROXIN, Claus. Derecho penal. Madrid: Civitas, 1997, p. 793.
} 
imputação subjetiva às exigências da prevenção geral, vindo a admitir a culpabilidade e a punição unicamente para reafirmar o conteúdo da norma ${ }^{179}$.

Da lição de Juarez Tavares se extrai que, como o Estado Democrático de Direito tem por base a proteção da dignidade humana e se orienta no sentido da proteção ao pluralismo político, deve ser compreendido juridicamente como um Estado garantidor das liberdades individuais e incrementador das características diversificadas de cada um de seus cidadãos, objetivando a realização integral das potencialidades humanas e de sua concreta execução dentro de uma política de integração e de participação popular ${ }^{180}$.

Hans Heinrich Jescheck se posiciona contrariamente à corrente doutrinária funcional que prega a prescindibilidade do princípio da culpabilidade, pois o princípio da culpabilidade serve também como uma proteção necessária do cidadão contra qualquer excesso na intervenção repressiva do Estado e a pena deve se limitar a incidir apenas sobre as condutas que merecem um juízo de desvalor ético-social ${ }^{181}$.

Substituir o princípio da culpabilidade ante uma suposta necessidade de prevenção geral, que se dá por meio da aplicação de pena, servirá somente para contrariar as premissas constitucionais de um Estado Democrático de Direito, haja vista, a finalidade da pena será não outro que o de manter a confiança da provação no Direito e de ordem pública.

Toda a análise principiológica feita neste capítulo leva à conclusão de que a utilização do sistema penal como fórmula de resolução de todos os conflitos sociais somente reforça seu aspecto instrumental, uma vez que a igualdade de tratamento do direito penal a todos os cidadãos revela-se um mito diante quando se atenta para as reais contradições existentes na sociedade.

E um Estado que respeita os limites dos princípios e garantias necessários a sua intervenção, que se baseiam no respeito aos direitos fundamentais, está observando e obedecendo aos requisitos essenciais da Política Criminal democrática.

\footnotetext{
${ }^{179}$ ROXIN, Claus. Estudos de Direito Penal. Tradução Luís Greco. 2.ed. Rio de Janeiro: Renovar, 2008, p. 144.

${ }^{180}$ TAVARES, Juarez. Culpabilidade: A Incongruência dos Métodos. Revista Brasileira de Ciências Criminais, ano 6, no 24. São Paulo: Editora Revista dos Tribunais, out-dez 1998, p. 151.

${ }^{181}$ JESCHECH, Hans Heinrich. El Principio de Culpabilidad Como Fundamento Y Límite De La Punibilidade En El Derecho Alemán Y Español. San Sebastián: Eguzkilore - Cuaderno del Instituto Vasco de Criminología, nº 9, 1995, p. 28/29.
} 


\section{A COCULPABILIDADE}

O crime, antes de ser uma construção da dogmática jurídica, é um fato social ${ }^{182}$.

Nilo Batista ${ }^{183}$ explica que se trata de considerar a concreta experiência social do acusado, as oportunidades que lhe foram ofertadas e a assistência que lhe foi ministrada, quando se for realizar o juízo de reprovabilidade acerca da conduta. A reprovação que vai recair sobre o criminoso se relaciona com as oportunidades e perspectivas que o corpo social apresenta ao indivíduo.

Nas sociedades pluralistas, as alternativas, as liberdades e as possibilidades de determinação de comportamento foram distribuídas desigualmente dentre os indivíduos, o que justifica que as diversas condutas sociais, lícitas e ilícitas, dependem da condição social à qual o agente pertence ${ }^{184}$.

Os ordenamentos jurídicos correspondem a catálogos de penalidades, sejam estas de natureza cível ou criminal, que identificam e punem os desvios; a punição tem por objetivo diminuir a emissão de uma resposta indesejável; assim sendo, pune-se o criminoso para que ele não mais viole as leis e se encarcera a fim de que ele pare com a emissão de respostas que causam dano à sociedade ${ }^{185}$.

Contudo, esta crítica de Murray Sidman corrobora a noção de que "burlando nós mesmos a lei, negamos emprego, escola e mesmo hospitalização para pessoas ${ }^{186, "}$

Juarez Tavares salienta que a culpabilidade somente responderia e corresponderia à justa reprovação do agir se estivesse atenta às especificidades do 'eu circunstanciado' do cidadão, ou seja, o delito corresponde a um comportamento do sujeito, logo, é um produto deste enquanto esteja o agente situado em um dado contexto social, no qual recebe orientação acerca dos valores que irá assimilar e sob os quais desenvolverá suas atitudes. Por isso, quando se analisa o sujeito, deve-se levar em conta todas as suas dimensões, ou seja, como pessoa individual e como pessoa situada num determinado contexto ${ }^{187}$.

Se ao indivíduo não for oferecido o espaço social saudável para seu desenvolvimento, sua capacidade de aprender os padrões de conduta impostos pela sociedade e de agir de acordo com as normas pode restar comprometida. Os padrões de

\footnotetext{
${ }^{182}$ BARATTA, Alessandro. Criminologia crítica e crítica do direito penal. 3. ed. Tradução de Juarez Cirino dos Santos. Rio de Janeiro: Revan: Instituto Carioca de Criminologia, 2002, p.153.

${ }_{183}$ BATISTA, Nilo. Introdução crítica ao direito penal brasileiro. 8. ed. Rio de Janeiro: Revan, p. 105.

${ }^{184}$ SANTOS, Juarez Cirino dos. A moderna teoria do fato punível. Curitiba: Lumen Juris, 2005, p. 231.

${ }^{185}$ SIDMAN, Murray. Coerção e suas implicações. Editora Livro Pleno, 2009, p. 40.

${ }^{186}$ Idem.

${ }^{187}$ TAVARES, Juarez. Teoria do injusto penal. 2. ed., Belo Horizonte: Del Rey, 2002, p. 100-101.
} 
conduta social são aprendidos a partir da participação ativa no corpo social, da interação com as outras pessoas e, dependendo do meio no qual a pessoas nasceu, cresceu, aprendeu valores, as condutas padrões se diversificam, ou seja, se a pessoa se formou em um ambiente no qual o Estado se fazia presente por meio da consecução dos direitos sociais, não terá o mesmo arcabouço de motivações que uma pessoa que viveu sem os pressupostos mínimos de dignidade. Se a desigualdade é tamanha, também deve ser diferente a mensuração do juízo de reprovação individual quando se estiver valorando um comportamento criminoso $^{188}$.

\section{1 - Origem histórica}

Em 15 de fevereiro de 1777, a imprensa francesa (Gazette de Berne) lançou um concurso que previa premiação para o trabalho que melhor apresentasse um plano de legislação penal ${ }^{189}$.

Para participar de referido evento, Jean Paul Marat elaborou o "Plano de Legislação Criminal”, datado de 1780, no qual apresentou seus estudos, e, apesar de sua proposta não ter sido a vencedora, acabou publicada em $1790^{190}$.

O Plano se constitui de quatro partes, tratando as duas primeiras de direito material e as duas outras de direito processual. Na primeira parte, Jean Paul Marat expõe os princípios fundamentais do que seria uma legislação justa e a análise inicial versa sobre a ordem social $^{191}$.

\footnotetext{
${ }^{188}$ MUÑOZ CONDE, Francisco. Teoria geral do delito. Tradução de Juarez Tavares e Luiz Regis Prado. Porto Alegre: Sergio Antonio Fabris, 1988, p. 130-131.

${ }^{189}$ Dizia o anúncio: "Um amigo da Humanidade que, contente em fazer o bem, deseja desviar-se do reconhecimento público escondendo seu nome, atingido pelos inconvenientes que nascem da imperfeição da maior parte dos Estados da Europa, fez chegar na associação econômica desta cidade um prêmio de cinqüenta luíses novos de ouro em favor da dissertação que a sociedade julgar o melhor sobre o objeto que segue: Compor e redigir um plano completo e detalhado da legislação criminal sob este triplo ponto de vista: $1^{\circ}$ ) De crimes e penas proporcionais que se trata de aplicar; $2^{\circ}$ ) Da natureza e força das provas e das presunções; $3^{\circ}$ ) Da maneira de obtê-las pela via do procedimento criminal, de tal modo que a brandura e a instrução das penas sejam conciliadas com a certeza de um castigo pronto a exemplar, e que a sociedade civil encontre a maior segurança possível para a liberdade da humanidade. Ainda que até o presente a sociedade se tenha aplicado de uma maneira mais particular à física e à agricultura, ela, entretanto, gosta muito da pesquisa da verdade e do útil para deixar de se encarregar com prazer da publicação de uma questão tão interessante para todas as nações e que tende a projetar novas luzes sobre uma das ramificações mais importantes da legislação. O prêmio será entregue no fim do ano de 1779, e as peças do concurso devem ser dirigidas ao doutor Tribolet, secretário perpétuo da sociedade, até julho de 1779. Elas poderão ser escritas em latim, francês, alemão, italiano ou inglês. O nome do autor será colocado num bilhete fechado, que terá a mesma divida do memorando que o acompanhará". (COQUARD, Oliver. Marat. Tradução: C. H. Silva. São Paulo: Scritta, 1996, p. 93).

${ }^{190}$ COQUARD, Oliver. Marat. Tradução: C. H. Silva. São Paulo: Scritta, 1996. p. 93

${ }^{191}$ MARAT, Jean-Paul. Plano de legislação criminal. Tradução: João Ibaixe Jr. e Carmensita Ibaixe - São Paulo: Quartier Latin, 2008, p. 21.
} 
Quando estipula no Plano a obrigação de todos se submeterem às leis, Jean Paul Marat ressalva que os indivíduos marginalizados do grupo social, aos quais não se realizam as garantias mínimas dos seus direitos fundamentais, não podem ser obrigados a respeitar a lei em razão disso ${ }^{192}$, ou seja, o Estado somente terá o direito de punir as pessoas que violam suas leis depois de haver cumprido com todas as obrigações para com todos os membros da sociedade.

Jean Paul Marat desenvolveu seus estudos analisando a vida de indivíduos voltados excessivamente à delinquência e constatou que essas pessoas não receberam nenhuma educação e que muitos deles poderiam ter-se distinguido por suas virtudes, caso tivessem sido "alimentados com lições de sabedoria" 193.

Vislumbra-se, assim, que, inspirado nas diferenças sociais entre os membros da mesma sociedade, Marat preconizava a necessidade de se atentar às condições pessoais de cada um no momento de se aplicar uma pena.

No século XIX, Karl Marx também sustentou que o direito corresponde a superestrutura ideológica da classe dominante para que a ela se submetam as classes inferiores, consequentemente, exploradas ${ }^{194}$, embora não tenha se aprofundado nos estudos vinculados ao Direito Penal ou à criminologia.

Acerca da presença positivada do conceito de coculpabilidade nos ordenamentos jurídicos, Eugenio Raul Zaffaroni assegura que este princípio já está previsto no Código Penal argentino desde $1921^{195}$.

Nilo Batista ressalta a presença da coculpabilidade no artigo $5^{\circ}$ inciso I do Código Penal da República Democrática da Alemanha de 1968, o qual dispunha que "uma ação é cometida de forma reprovável quando seu autor, não obstante as possibilidades de conduta socialmente adaptada que lhe tenham sido oferecidas, realiza por atos irresponsáveis, os elementos legalmente constitutivos de um delito ou de um crime" 196.

Em 1979, Heleno Claudio Fragoso reconhecia que a criminalidade encontrava relação com a condição opressiva das estruturas sociais, a qual se configurava, na visão do

\footnotetext{
${ }^{192}$ Idem, p.75.

${ }^{193}$ Idem, p. 81.

${ }^{194}$ MARX, Karl. Apud ZAFFARONI, Eugenio Raul; PIERANGELI, José Henrique. Manual de Direito Penal brasileiro: parte geral. São Paulo: Editora Revista dos Tribunais, 2008, p. 248.

195 ZAFFARONI, Eugenio Raul. Teoria del delito. Buenos Aires: Editar, 1973, p. 541.

${ }^{196}$ BATISTA, Nilo. Op.cit.,p. 105.
} 
autor, injusta e desigual, e, neste ensejo, criticava a tentativa de se resolver os problemas sociais com a incidência de sanções penais ${ }^{197}$.

A esta noção é possível se atrelar a ideia da teoria da coculpabilidade, haja vista, esta teoria reconhece as desigualdades que emergem dentro da sociedade e pode funcionar como critério que corrige a tão criticada seletividade do sistema penal.

Dessa forma, a sociedade passa a ter também o dever de assegurar a todos os cidadãos os meios necessários para uma sobrevivência digna. Quando não o faz, acaba por propiciar aos indivíduos excluídos o cometimento de condutas criminosas, já que esses seres humanos são colocados às margens da sociedade e compelidos pela miséria, com precária situação econômica, e praticamente nenhuma formação intelectual ou escolar, o que atesta o fracasso daquela sociedade no que atine às garantias básicas dos direitos sociais de seus cidadãos ${ }^{198}$.

George Rusche e Otto Kirchheimer relembram em sua obra que as condições sociais já serviram de base para a determinação da pena, porém, ao passo que hoje se defende atenuar a reprovalibilidade da conduta do infrator pertencente às classes menos abastadas, já se viu a classe dominante da burguesia receber penas mais brandas como a multa e a classe baixa ter de suportar as penas corpóreas ou de prisão ${ }^{199}$.

Assim, a coculpabilidade representa o reconhecimento da quebra do contrato social por parte do Estado.

Entretanto, existem também outras menções acerca do surgimento da teoria da coculpabilidade. Em seus estudos sobre o tema, Grégore Moura ${ }^{200}$ aponta que também se cogita a possibilidade de este conceito estar arraigado ao momento em que emergiram os direitos socialistas.

Quem partilha do surgimento de que a coculpabilidade é produto dos ordenamentos jurídicos socialistas, tal qual Juan Andrés Cumiz ${ }^{201}$, justifica essa conclusão a partir das ideias marxistas que visavam se valer do Direito para acabar com as desigualdades socioeconômicas, formulando-se críticas à sua função ideológica, que tinha por escopo sustentar o Estado Capitalista.

\footnotetext{
${ }^{197}$ FRAGOSO, Heleno Cláudio. O Direito Penal comparado na América Latina. Revista de Direito Penal, $\mathrm{n}$. 24, Rio de Janeiro, 1979, p. 17-25.

${ }^{198}$ CARVALHO, Salo de. Pena e Garantias. Rio de Janeiro: Lumen Juris, 2003, p. 51-52.

${ }^{199}$ RUSCHE, George; KIRCHHEIMER, Otto. Op.cit., p. 112.

${ }^{200}$ MOURA, Grégore Moreira de. Do princípio da co-culpabilidade no direito penal. Rio de Janeiro: Impetus, 2006, p. 41.

${ }^{201}$ CUMIZ, Juan Andrés. Apud MOURA, Grégore Moreira de. Op.cit., p. 42.
} 
Insta salientar que o direito socialista se fundamenta em veemente oposição ao sistema capitalista, visando extinguir as desigualdades socioeconômicas, através da eliminação de todas as mazelas trazidas pelo modo de produção capitalista. Assim, vislumbra-se que a principal proposta do direito penal socialista é que se analise o direito de uma determinada sociedade considerando-se este como o produto das condições econômicas que imperam naquele país. Isso corrobora a busca pela igualdade material e fundamenta que a ideia de coculpabilidade tenha se originado das premissas do direito socialista $^{202}$.

Para os adeptos dessa teoria acerca do surgimento da coculpabilidade, prevalece o entendimento de que este princípio corresponde ao reconhecimento de referida igualdade material por meio da corresponsabilização do Estado, que não criou oportunidades iguais de inclusão social aos seus cidadãos, restando, assim, inadimplente perante estes.

Contudo, faz-se mais plausível considerar que a origem histórica da coculpabilidade acaba por se confundir com o nascimento do próprio Estado Liberal, este, por sua vez, alicerçado nas premissas iluministas e embasado na teoria do contrato social.

A Revolução Francesa de 1789, que perseguia os ideais da liberdade, da igualdade e da legalidade, objetivava a constituição de um Estado de Direito baseado na razão; este é o marco histórico da queda do Estado Absolutista e do nascimento do Estado Liberal.

Este, na concepção de Jorge Miranda, caracteriza-se por apresentar "em vez da tradição, o contrato social; em vez da soberania do príncipe, a soberania nacional e a lei como expressão da vontade geral; em vez do exercício do poder por um só ou seus delegados, o exercício por muitos, eleitos pela coletividade ${ }^{203}$ ". Foi neste contexto que se passou a tratar de assuntos como a ética, a democracia e a liberdade à luz da razão. Segundo Pepe, a sociedade se viu diante de um novo rumo com a substituição do "estado de natureza" pelo "Estado de Direito" 204.

O Estado, agora liberal, assume a função de proporcionar o desenvolvimento humano e social dos homens, que passaram a serem seus cidadãos. A liberdade constitui a essência desse tipo de governo, configurando-se verdadeira garantia individual e ensejando a igualdade de oportunidades ${ }^{205}$.

\footnotetext{
${ }^{202}$ MOURA, Grégore Moreira de. Op.cit., p. 43.

${ }^{203}$ MIRANDA, Jorge. Teoria do Estado e da constituição. Rio de Janeiro: Forense, 2007, p.45.

${ }^{204}$ PEPE, Albano Marcos Bastos. Kant e a modernidade jurídica: razão e liberdade. In: COPETTI, André; STRECK, Lenio Luiz; ROCHA, Leonel Severo (Org.). Constituição, sistemas sociais e hermenêutica. Porto Alegre: Advogado, 2006, p. 10-11.

205 STRECK, Lenio Luiz; MORAIS, José Luis Bolzan de. Ciência política e teoria do Estado. 5. ed. rev. e atual. Porto Alegre: Livraria do Advogado, 2006, p. 62.
} 
Também foi com o Estado Liberal de Direito que se disseminou a ideia de direitos humanos naturais, inalienáveis e inatacáveis, ou seja, os direitos tornaram-se inerentes ao qualificativo humano e, consequentemente, oponíveis ao próprio Estado. A evolução nesse aspecto foi visível, pois, anteriormente ao liberalismo, os direitos eram concedidos a algumas pessoas pelo soberano ${ }^{206}$.

Enfim, com as ideias iluministas sendo aplicadas pelos Estados Liberais, favoreceuse o liberalismo, evidentemente, e também o individualismo de forma exacerbada; isso proporcionou um aumento das desigualdades sociais, acompanhada da sensação de que o Direito é um instrumento de controle social que incide somente em relação às classes inferiores; desta feita, pode-se entender que a corresponsabilidade do Estado no cometimento de crimes é produto do Estado liberal e de seu contratualismo, uma vez que há o rompimento do contrato social quando o órgão de tutela deixa de assegurar o mínimo de condições de desenvolvimento humano e social ao indivíduo.

O crime também se revela uma quebra do contrato social, porém que sujeita seu autor à incidência de uma pena que, na maioria das vezes, restringirá sua liberdade, segregando-o ao cárcere e isso se dará por meio do exercício do direito de punir por parte do Estado, do mesmo Estado que também rompeu o contrato social, aliás, tornou-se inadimplente perante o indivíduo antes mesmo de este se tornar inadimplente em relação à sociedade.

Nos Estados em que não se consegue efetivar os direitos sociais para as camadas da população que mais necessitam, acaba-se por inflamar o discurso do recrudescimento penal, estimulando-se a adoção de medidas mais repressivas a fim de conter o medo dos ocupantes das classes médias e altas.

Desta feita, tem-se que o sistema penal se revela seletivo porque não protege igualmente todos os bens essenciais à coletividade, vindo a perseguir e punir de formar mais incisiva os indivíduos que apresentam comportamentos contrários ao modo hegemônico de acumulação, flexibilizando-se, assim, a aplicação da lei penal quando se trata de crimes mais nocivos à coletividade como um todo.

Então, tendo-se a culpabilidade como juízo de reprovabilidade da conduta que possibilita a aplicação da pena em relação àquela pessoa, é possível compensar a

\footnotetext{
${ }^{206}$ ESPINDOLA, Ângela Araujo da Silveira. A Crise Conceitual e a (re)construção interrompida da Soberania: o fim do Estado-Nação? In: MORAIS, José Luis Bolzan de (Org.). O Estado e suas crises. São Paulo: Companhia das Letras, 2005, p. 46.
} 
culpabilidade de um indivíduo, observando a inadimplência primária do Estado em relação a ele e, assim, limitar a incidência do direito de punir.

\section{2 - As teorias criminológicas que embasam o conceito de coculpabilidade}

Antes de se conceituar propriamente o princípio da coculpabilidade e de situa-lo no âmbito do Direito brasileiro, importa demonstrar seu conteúdo e compreender a importância que ele carrega. Para tanto, conta-se com a singular contribuição proporcionada pelas teorias sociológicas da criminologia.

Entre os séculos XVIII e XIX, a Escola Liberal Clássica do Direito Penal, influenciada pelo Iluminismo liberal, visualiza o crime como resultado de uma escolha interna do sujeito infrator, que se calca no livre arbítrio do indivíduo e se situa em uma realidade ontológica pré-constituída, ou seja, abstrai-se o fato tanto do delito, quanto do contexto ontológico que o correlaciona à personalidade do delinquente e a toda sua história biológica e psíquica ${ }^{207}$.

Alessandro Baratta explica que esta corrente se detinha principalmente sobre o conceito jurídico do delito, isto é, o delito considerado violação não apenas do direito, mas também do pacto social que baseou o Estado. Enquanto comportamento humano, a vontade de cometer o crime se originava de forma livre no indivíduo, e por isso, o delinquente não era diferente do cidadão normal.

A Escola Positiva do Direito Penal ou Criminologia Positivista, que teve por expoentes Cesare Lombroso, Enrico Ferri e Raffaele Garofalo, emerge entre o final do século XIX e início do século XX, preconizando a aplicação de um método experimental e negando tanto a culpabilidade individual como o livre arbítrio ${ }^{208}$.

Segundo esta corrente filosófica, que confere a explicação para o fenômeno da criminalidade sob o enfoque etiológico, é possível se identificar no delinquente uma série de causas biológicas, psicológicas ou sociais que o levaram à prática do crime ${ }^{209}$.

Acerca dessa escola, Vera Regina Pereira de Andrade ${ }^{210}$ considera a Criminologia Positivista como uma ciência causal explicativa da criminalidade, esta concebida como fenômeno natural e causalmente determinado, que, pelo método experimental, possui a tarefa de explicar as suas causas, bem como de, com o auxílio das estatísticas criminais

\footnotetext{
${ }^{207}$ BARATTA, Alessandro. Op.cit., p. 38.

${ }^{208}$ CONDE, Francisco Muñoz; HASSEMER, Winfried. Introdução à Criminologia. Tradução: Cíntia Toledo Miranda Chaves. Rio de Janeiro: Lúmen Juris, 2008, p. 25.

${ }^{209}$ Idem, p. 20.

${ }^{210}$ ANDRADE, Vera Regina Pereira de. Sistema Penal Máximo X Cidadania Mínima: Códigos da violência na era da globalização. Porto Alegre: Livraria do Advogado, 2003, p. 35
} 
oficiais, descobrir os remédios para combatê-la; o indivíduo criminoso se distingue dos demais indivíduos pelo que fez.

A fim de superar aquela concepção de que o delito era um fenômeno natural e na tentativa de se estabelecer um estudo empírico sobre a criminalidade e sobre o homem infrator, em 1876, Cesare Lombroso publica a Obra L'uomo delinqüente, na qual apresenta a tese do criminoso nato, segundo a qual a causa do crime pode ser identificada no próprio criminoso.

Desta feita, a Criminologia Positivista desenvolve sua argumentação a partir do fato de que o criminoso é um doente e, sendo assim, deve-se dirigir o tratamento adequado sobre o elemento sintomático da sua personalidade a fim acentuar as características do delito; isto ocorrerá por intermédio das pesquisas empíricas ${ }^{211}$.

Vera Regina Pereira de Andrade ${ }^{212}$ aduz ainda que a doutrina da Criminologia Positivista tem por foco não apenas o diagnóstico da patologia criminal, mas estudar o remédio que seja capaz de cura-la; traz-se, assim, o discurso do combate ao mal da criminalidade em defesa do bem da sociedade que se ampara na ciência e se vislumbra a possibilidade de, com uma explicação científica das causas, trava-se uma luta científica contra a criminalidade, colocando-se o criminoso como destinatário de uma política criminal de base igualmente científica.

Isto porque, para se compreender o delito, que se faz presente na história da humanidade desde os primórdios, e o delinquente, é imprescindível analisar o contexto social da época, por meio das concepções filosóficas que vigoravam em determinado momento histórico, suas estruturas sociais, econômicas e políticas com o objetivo de alcançar a relação existente entre o ser humano, o Estado e a sociedade, pois essas circunstâncias se modificam ao longo dos tempos e com a evolução ${ }^{213}$.

O comportamento do indivíduo, dentro do contexto do comportamento do grupo, constitui-se fundamental para compreender o delito como fenômeno social.

A criminalidade corresponde a um problema político, porque o Direito Penal, com base nos valores sociais dentro da comunidade e social, normatiza as condutas consideradas transgressoras, e também a um problema social, já que afeta a sociedade

\footnotetext{
${ }^{211}$ BARATTA, Alessandro. Op.cit., p. 39.

212 ANDRADE, Vera Regina Pereira de. Op.cit., p. 38

${ }^{213}$ CAPRA, Fritjof. O ponto de mutação. São Paulo: Cultrix, 2006, p. 14.
} 
como um todo e, por isso, a sociedade toda clamará uma solução. Deste modo, vislumbrase que o problema da criminalidade possui caráter complexo e interdisciplinar ${ }^{214}$.

Émile Durkheim vislumbrava o crime como algo normal e funcional, que oferecia sua contribuição para o desenvolvimento social por propiciar mudanças em qualquer tipo de sociedade e levar o grupo a repensar seus valores ${ }^{215}$.

Nesse sentido, o crime revela-se saudável à evolução social dentro de certos limites, senão ocorre o que Émile Durkheim chama de 'anomia', que corresponde à perda de efetividade das normas e valores vigentes em uma sociedade ante o acelerado crescimento econômico que nela se opera; isto, por sua vez atinge a consciência coletiva e faz com que a taxa de criminalidade tenha que ser controlada ${ }^{216}$.

Readaptando a teoria de Durkheim, Merton propôs uma nova significação para o termo 'anomia', a qual corresponde ao conflito entre os fins idealizados pela sociedade e os meios que ela proporciona aos seus membros para a consecução de tais metas ${ }^{217}$.

À semelhança de Émile Durkheim, também Robert Merton baseia sua análise sobre os perigos inerentes à defasagem entre as necessidades humanas e os meios disponíveis para sua satisfação, mobilizando todo um manancial de dados retirados da experiência americana de sua época para demonstrar de forma concreta as consequências do conflito entre os objetivos culturais e as normas institucionais ${ }^{218}$.

Robert Merton concluiu de suas pesquisas nesse sentido que é a falta de entrosamento entre os alvos propostos pelo ambiente cultural e as possibilidades oferecidas pela cultura social que pressiona o desvio de comportamento de uma pessoa. Segundo ele, os recursos legítimos para que se possa ingressar e integrar em uma sociedade capitalista são limitados por uma estrutura de classe a qual não é livremente acessível a todos, de modo que, o caminho para o êxito é, no mínimo, difícil para as pessoas de pouca instrução e de pouco dinheiro ${ }^{219}$.

Vislumbra-se que já em Robert Merton se fazia presente a crítica de que o Estado é inadimplente para com seus cidadãos por não disponibilizar os meios institucionalizados ao acesso de todos e tampouco concretizar a igualdade de oportunidades aos membros de uma mesma sociedade.

\footnotetext{
${ }^{214}$ RODRÍGUEZ, Laura Zúñiga. Política criminal. Madrid: Colex, 2001, p. 98.

${ }^{215}$ DURKHEIM apud MOLINA, Antonio Garcia Pablos; GOMES, Luiz Flavio. Criminologia. 4.ed. São Paulo: Editora Revista dos Tribunais, 2002, p. 350.

${ }^{216}$ Idem, p. 351.

${ }^{217}$ MERTON, Robert K. Sociologia: teoria e estrutura. São Paulo: Mestre Jou, 1970, p. 204.

${ }^{218}$ MANNHEIM, Hermann. Criminologia. Vol.II. Lisboa: Fundação Calouste Gulbenkian, 1985, p. 768.

${ }^{219}$ MERTON, Robert K. Op. cit., p. 218 e 219.
} 
Torna-se possível, então, dizer que a teoria de Robert Merton viabiliza sustentar uma reprovabilidade mais branda aos indivíduos que sofrem em demasia essa pressão anômica, unicamente por ocuparem uma classe social menos favorecida e que, pela inadimplência estatal, resta estagnada no que tange à ascensão dentro do grupo.

Por tudo isso, resta nítida a contribuição do pensamento de Robert Merton, que demonstrou a perversidade contida em uma estrutura social, pois, ao mesmo tempo em que dissemina para a população a ideia que determinados bens de consumo fazem-se imprescindíveis à ascensão social e coloca isso como valor máximo daquela sociedade, também impede que determinadas pessoas tenham acesso aos bens que as propiciem alcançar referido objetivo.

Dai se desenvolveram pesquisas acerca da formação de subculturas delinquentes compostas por jovens, observando em seus estudos que, ante a dificuldade para chegar às metas culturais impostas pela sociedade, os jovens se agrupariam buscando entre si pontos de identificação e encontrando força para reagir à tamanha incongruência ${ }^{220}$.

Albert Cohen estudou as subculturas delinquentes e considerou que a impossibilidade de se alcançar as metas sociais pode repercutir de tal maneira em um jovem de classe baixa que, vendo-se estagnado na pobreza e condenado perpetuamente a isso, poderá ocasionar nele uma mudança generalizada de valores que o conduz a, não apenas renunciar as normas postas da sociedade, mas também questionar se esses objetivos preconizados pelo grupo são positivos. Quando este questionamento ocorre, diz-se que ocorre também a alteração na moldura de referências daquele jovem ${ }^{221}$.

Agregando-se a uma subcultura, o jovem passa a ter a sensação de estar integrado em um grupo, o que lhe confere segurança para eleger as condutas que irá adotar e, assim, formar sua identidade, decidindo entre o que julga lícito ou ilícito dentro da nova moldura $^{222}$.

Em uma sociedade excludente e dividida em classes, mas que, no entanto, dissipa um discurso pérfido de homogeneidade, constantemente se verá a formação de novas subculturas na tentativa de que os indivíduos marginalizados se adaptem e sobrevivam juntos e entre semelhantes dentro de outra cultura que não é a dominante.

\footnotetext{
${ }^{220}$ MOLINA, Antonio Garcia Pablos; GOMES, Luiz Flavio. Op.cit., p. 369.

${ }^{221}$ COHEN, Albert K. apud SHECAIRA, Sérgio Salomão. Criminologia. 2.ed.rev.,atual.,ampl. Editora Revista dos Tribunais, p. 45.

${ }^{222}$ COHEN, Albert K. Delinquent boys: the culture of the gang. Londres: Routledge \& Kegan Paul, 1956, p. 56.
} 
Pode-se dizer, então, que a delinquência subcultural emerge como resposta a um estímulo aversivo aos padrões impostos pela classe média, que prega um consumismo desenfreado e rotula as pessoas como próprias ou impróprias para pertencerem ao grupo, de acordo com o que elas compram e possuem, mas, ao mesmo tempo, nada faz para realizar o ideal de 'igualdade de oportunidades para todos' e segrega aqueles que ocupam uma classe social com menor poder aquisitivo, obrigando-os, ante a necessidade humana de se socializar, que se feche em novos subgrupos, os quais poderão inclusive desenvolver regras e valores distintos dos vigentes naquela sociedade que os marginalizou.

A teoria criminológica do "labelling approach", também chamada de rotulação social ou do etiquetamento ou interacionista ou da reação social, corrobora as críticas já expostas, principalmente no que tange à atribuição de rótulos entre os membros da sociedade, ao constatar que o sistema penal seleciona, marginaliza e exclui as pessoas que não se encaixam no modelo idealizado de cidadão ${ }^{223}$.

Segundo essa teoria, as relações sociais nas quais as pessoas estão inseridas as condicionam reciprocamente e é mediante o processo de interação com as outras que se tornam seres sociais capazes de assumir diversas identidades ${ }^{224}$.

Dessa forma, a sociedade separa e cataloga quem pertence efetivamente ao grupo por contribuir com ele de alguma forma, haja vista a principal demanda de uma sociedade de consumo é a ascensão, e quem restará às margens, como se não fizesse parte do todo.

Segundo Alessandro Baratta, chama-se criminalização primária aquela que se opera no âmbito do Poder Legislativo, quando o legislador seleciona quais os bens serão juridicamente tutelados pelo Direito Penal e quais as condutas serão definidas como crime pela edição de leis incriminadoras, e se chama criminalização secundária, aquela realizada pelos órgãos do sistema penal, quando aplicam o comando normativo abstrato, aqui se salienta a função do Poder Judiciário, uma vez que este possui a incumbência de atribuir ou não a etiqueta de criminoso àqueles que transgrediram as regras penais. Assim, o Estado define em lei as condutas tidas como ilícitas para, posteriormente, selecionar aqueles que responderão pelos fatos criminosos caindo na engrenagem do sistema repressivo ${ }^{225}$.

Especificamente acerca da criminalização secundária, referido autor explica que seus mecanismos acentuam de forma mais veemente o caráter seletivo do Direito Penal e, no que tange à seleção dos indivíduos, o paradigma mais eficaz para a sistematização dos

\footnotetext{
${ }^{223}$ SHECAIRA, Sérgio Salomão. Op.cit, p. 286.

${ }^{224}$ Idem, p. 287.

${ }^{225}$ BARATTA, Alessandro. Op.cit., p. 165.
} 
dados da observação é o que assume como variável independente a posição ocupada pelos indivíduos na escala social ${ }^{226}$.

Segundo a obra de Francisco Muñoz Conde e Winfried Hassemer, o Direito Penal faz o delinquente sem nenhum respeito pelo princípio da igualdade, uma vez que recai com maior incidência sobre as camadas sociais mais baixas do que sobre as demais ${ }^{227}$.

Diante disso, pode-se dizer que esta corrente deslegitima discursos ideológicos que ocultam os interesses da minoria detentora do poder, haja vista o discurso penal latinoamericano reveste-se de sabida falsidade e a perversão é a característica que cristaliza a dinâmica discursiva do discurso jurídico-penal, apesar de sua evidente falsidade ${ }^{228}$.

O fato de as agências oficiais do controle social possuir funções não declaradas denuncia que, em uma sociedade capitalista estruturada em classes sociais tão antagônicas e que é marcada por uma discrepante concentração de renda e desigualdade de acesso às oportunidades, enseja que a repressão penal por parte do Estado não se dá de forma equânime, mas seletiva e que alcança de maneira mais veemente a classe desprovida de poder econômico, político, cultural e jurídico.

Assim, deve-se analisar essa nítida relação de luta dos contrários, para se compreender a atuação do sistema penal, uma vez que os mecanismos seletivos do processo de criminalização se relacionam diretamente com a estrutura e as leis de desenvolvimento da formação econômico-social ${ }^{229}$.

Disso se depreende que a produção do material legislativo orienta-se em consonância com os ditames da economia de livre mercado e se respalda em uma discrepante desigualdade punitiva na sociedade ${ }^{230}$.

Becker considerava o desvio como a consequência visível da reação social a um dado comportamento, não estando no ato cometido, tampouco naquele que o comete. Logo, chamar o criminoso de 'ser desviante' corresponde ao resultado de um processo de etiquetamento que ocorre cotidianamente na sociedade. $\mathrm{O}$ autor explica que a desviação é criada pelos grupos sociais por meio da elaboração de normas que definem a infração e, por sua vez, esta acaba por constituir a cediça desviação, e também por meio da aplicação

\footnotetext{
${ }^{226}$ Idem.

${ }^{227}$ CONDE, Francisco Muñoz; HASSEMER, Winfried. Op.cit., p. 112.

${ }^{228}$ ZAFFARONI, Eugenio Raul. Op.cit., p. 14.

${ }^{229}$ BARATTA, Alessandro. Op.cit., p. 161.

${ }^{230}$ VILA NOVA, Sebastião. Introdução à sociologia. 4.ed.rev.e aum. São Paulo: Atlas, 1999, p. 74-75.
} 
dessas normas definidoras da conduta desviante aos indivíduos já etiquetados como excluídos ou "outsiders" 231.

Com base nesta análise, Becker conclui que a desviação, portanto, corresponde a uma consequência da aplicação das normas e sanções a um ofensor e não uma qualidade do ato cometido pela pessoa. O desviado, por sua vez, é a pessoa a quem se tenha aplicado o rótulo com êxito, isto quer dizer, a pessoa foi rotulada e internalizou a etiqueta; desta forma, a conduta desviada vem a ser o comportamento assim designado pela norma incriminadora.

Visto que a teoria da reação social se preocupa com o elemento que define o desvio e, consequentemente, a criminalidade, então, é possível concluir que o delito não é uma qualidade de uma determinada conduta, mas corresponde ao resultado de uma definição que se dá pelas instâncias de controle social.

Tal definição recai sobre a sociedade de modo desigual, restando o prejuízo como atribuição às pessoas ocupantes das classes sociais mais baixas. Vale frisar aqui que, embora pessoas das classes mais abastadas também cometam crimes, as cifras negras demonstram que a possibilidade de se escapar de uma definição jurídico-penal cresce à medida que se sobe na hierarquia social ${ }^{232}$.

Segregados às margens da sociedade, embaixo de pontes e nas favelas, os rotulados como 'persona non grata' nesse processo de etiquetamento passam a interagir entre si, buscando seus pontos de convergência. Isso desencadeia a formação de uma nova sociedade, uma sociedade paralela, na qual se terá um líder, que pode ser tanto o traficante quanto o pastor da igreja, e, sob esses novos parâmetros, as pessoas ocupantes daquela comunidade passam a se identificar e ocorre o que Burrhus Frederic Skinner chama de processo de imitação ${ }^{233}$, ou seja, as pessoas elegem os comportamentos que vão adotar com base no que tomam por referência de vida.

Gabriel Tarde também desenvolveu pesquisas criminológicas, das quais concluiu que os fatores sociais preponderam no estudo das causas do crime. Para este autor, qualquer comportamento se origina a partir das influências sociais, por intermédio das 'leis da

\footnotetext{
${ }^{231}$ BECKER, Howard S. Outsiders. New York: Free Press, 1.963, p. 8-9.

${ }^{232}$ HASSEMER, Winfried; CONDE, Francisco Muñoz. Introducción a la Criminología y al Derecho Penal. Valência: Tirant lo Blanch, 1.989, p. 59-60.

${ }^{233}$ SKINNER, Burrhus Frederic. Ciência e comportamento humano. Editora Martins Fontes, 2007, p. 341.
} 
imitação', ou seja, para que um determinado comportamento possa ser executado, antes ele deve ser aprendido ${ }^{234}$.

Em sua obra "As leis da imitação", Gabriel Tarde cita Taine para explicar que o ser humano teria predisposição à imitação, por ser o cérebro um órgão naturalmente repetidor $^{235}$. Atrelado a isso está a ideia de que o ambiente sugestiona seus membros, uns com mais intensidade, outros com menos, mas, em certos casos, de tal maneira que acaba por inibir qualquer possibilidade de reflexão crítica a respeito do que imitar ou não.

Étienne De Greeff reconhece que manifestações coletivas podem exercer influência tão grande no indivíduo que é capaz de leva-lo a regredir, ainda que momentaneamente, a um fundo residual de agressividade existente em todos os seres humanos como herança de seus ancestrais primitivos ${ }^{236}$.

Erving Goffman ${ }^{237}$ compara a vida com uma peça teatral para explicar o modo como os indivíduos atuam enquanto sociedade. Segundo o autor, cada indivíduo possui uma função, um papel a ser desempenhado e uma conduta a ser adotada perante a sociedade. Quando sofre o processo de estigmatização, o sujeito se vincula e é vinculado ao papel que lhe é impingido. Uma vez desvirtuada sua atuação (extrapolando ou desviando sua conduta daquela que é dele esperada), o sujeito perde a legitimação para desempenhá-la.

Edwin Sutherland ${ }^{238}$ amparou-se nas pesquisas de Skinner, mencionadas acima, bem como no trabalho de Gabriel Tarde ${ }^{239}$ e, ao estudar a teoria criminológica da associação diferencial, corroborou o entendimento de que o crime é um comportamento socialmente aprendido por meio do processo de comunicação, ou seja, é uma resposta comportamental oriunda de um estímulo operante e conclui que um indivíduo se torna delinquente quando recebe a contingência de agentes reforçadores positivos em derivação à conduta ilícita praticada.

Corrobora ainda tal fundamentação, o preâmbulo da Convenção Americana sobre Direitos Humanos - Pacto de San Jose da Costa Rica - ao dispor que “(...) só pode ser realizado o ideal do ser humano livre, isento do temor e da miséria, se forem criadas

\footnotetext{
${ }^{234}$ TARDE, Gabriel. As multidões e as seitas criminosas. In: A opinião e as massas. Tradução de Eduardo Brandão. 2.ed. São Paulo: Martins Fontes, 2005, p. 181.

${ }^{235}$ TARDE, Gabriel. Les loies de l'imitation. 6.ed. Paris: Alcan, 1911, p. 80.

${ }^{236}$ DE GREEFF, Étienne. Introduction à la criminology. Vol.1. Paris: PUF, 1948, p. 209.

${ }^{237}$ GOFFMAN, Erving. A representação do eu na vida cotidiana. Petrópolis: Vozes, 1999, p. 133.

${ }^{238}$ SUTHERLAND, Edwin. H. Princípios de criminologia. Tradução Asdrúbal M. Gonçalves. São Paulo: Livraria Martins, 1949, p. 12 - 16.

${ }^{239}$ TARDE, Gabriel. Op.cit.
} 
condições que permitam a cada pessoa gozar dos seus direitos econômicos, sociais e culturais, bem como dos seus direitos civis e políticos ${ }^{240,}$.

Insta lembrar a lição de Antonio García-Pablos de Molina no sentido de que os conceitos de crime e de reação social são interdependentes, uma vez que, segundo a análise que este autor faz da teoria interacionista, uma conduta é socialmente considerada como infração após passar por um processo seletivo e discriminatório de valoração, no qual se selecionam e etiquetam pessoas e comportamentos como criminosos pelas mais diversas razões. Por isso, o indivíduo torna-se vítima dos processos de definição e seleção realizados por aqueles que definem e exerce o controle o social ${ }^{241}$.

É com esta visão propiciada pelo advento do paradigma da reação social, que a coculpabilidade passa a ser analisada sob uma nova ótica que considera aspectos sociológicos do crime, ou seja, não centra as atenções apenas no criminoso, mas na sociedade da qual ele integra e que o influencia.

Isto porque a criminologia crítica vislumbra que é função também da Hermenêutica Jurídica interpretar as normas penais de forma seletiva, a fim de se neutralizar os interesses de uma classe dominante em face aos dominados, uma vez é por meio da exegese que se acionam os mecanismos aptos a designar alguém como criminoso ou não ${ }^{242}$.

Inexoravelmente, o sistema penal prevalece em uma sociedade estratificada em diversas classes, sejam estas diferenciadas pelo poder econômico ou, por exemplo, pelo gênero, entre outras especificações. Dessa forma, tem-se que as decisões judiciais vêm permeadas por certos estereótipos, bem como existe um senso comum acerca da criminalidade, a qual se respalda hoje na exclusão do diferente ${ }^{243}$.

Por determinados estereótipos se obtém antecipadamente a figura do delinquente, como sendo aquele sujeito de negro ou pardo que ocupa uma classe pobre e, por isso, marginalizada, a qual é considerada pretensamente perigosa. O senso comum, por sua vez, reproduz a ideologia da defesa social e acaba dividindo a sociedade pela rotulação, etiquetando uns como bons e outros como maus ${ }^{244}$.

\footnotetext{
${ }^{240}$ CONVENÇÃO AMERICANA DE DIREITOS HUMANOS. Costa Rica, 1969. Preâmbulo.

${ }^{241}$ MOLINA, Antonio García-Pablos de. Criminología: Una Introducción a sus fundamentos teóricos para Juristas. Valencia: Tirant lo Blanch, 1.996, p. 226-227.

${ }^{242}$ NEPOMOCENO, Alessandro. Além da Lei. A face obscura da sentença penal. Rio de Janeiro: Revan, 2004 , p. 62.

243 Idem.

${ }^{244}$ Idem, p. 64.
} 
Segundo Zygmunt Bauman ${ }^{245}$, cada vez mais o fato de a pessoa ser pobre é encarado pelos indivíduos ocupantes de classes sociais superiores como um crime; o ato de empobrecer já configuraria predisposição ao cometimento de delitos e, por esta linha de raciocínio, as pessoas de classes desfavorecidas, ao invés de receberem assistência por parte do governo e solidariedade por parte dos cidadãos abastados, são vistos como merecedores de ódio e condenação.

Por sua vez, Alessandro Baratta ${ }^{246}$ considera isso como mera ideologia que acoberta a realidade de que o sistema penal confere privilégios aos interesses das classes dominantes, quando afasta do processo de criminalização determinados comportamentos típicos somente porque foram praticados por indivíduos a estas pertencentes e que estejam, de alguma forma, vinculados à acumulação de capital, restando assim às classes subalternas suportarem as consequências do processo de criminalização que lhes afeta diretamente.

Alessandro Nepomoceno corrobora o pensamento de referido autor argumentando que a mencionada seletividade qualitativa do sistema penal visa apenas legitima-lo no que tange às funções declaradas que, em verdade, não serão cumpridas, ou seja, faz-se um discurso no sentido de combater o crime através da repressão contra todos que atingirem um bem jurídico, seja este individual ou coletivo, entretanto, essas funções não podem ser desempenhadas porque a lógica do sistema penal é a seletividade que atinge os setores mais vulneráveis da estrutura social ${ }^{247}$.

\section{3 - Conceito}

Considerando-se a realidade seletiva do sistema penal, cabe ao Poder Judiciário limitar esta seletividade quando for chamado a intervir.

Para Eugenio Raul Zaffaroni, o que baliza essa intervenção do Poder Judiciário no sistema penal é a teoria do delito, uma vez que ela se compõe dos requisitos que devem estar presentes antes de se decidir afirmativamente pelo prosseguimento do processo de criminalização $^{248}$.

Correspondem estes requisitos, inicialmente, à tipicidade e antijuridicidade, que formam o injusto penal. Contudo, não basta somente isso para que a agência judicial tenha

\footnotetext{
${ }^{245}$ BAUMAN, Zygmunt. O mal-estar da pós-modernidade. Rio de Janeiro: Jorge Zahar, 1998, p. 57.

${ }^{246}$ BARATTA, Alessandro. Op.cit., p. 165.

${ }^{247}$ NEPOMOCENO, Alessandro. op. cit., p. 64.

${ }^{248}$ ZAFFARONI, Eugenio Raul. Em busca das penas perdidas: a perda da legitimidade do sistema penal. Tradução: Vânia Romano Pedrosa e Amir Lopes Conceição. Rio de Janeiro: Revan, 2001, p. 246.
} 
por configurado o injusto e emita a resposta criminalizante, mas necessita também que esteja presente a culpabilidade, conceito este que, após a evolução das teorias da culpabilidade, passou a se constituir de elementos técnicos.

Entretanto, na visão de Eugenio Raul Zaffaroni, essa seletividade que opera no âmbito do sistema penal pelo uso da pena acaba por deslegitimar a reprovação incutida na culpabilidade, uma vez que a pena reproduz a violência e tem por principal finalidade legitimar o exercício de poder de punir que é muito mais amplo do que o poder dos juristas $^{249}$.

Depreende-se da lição de Eugenio Raul Zaffaroni que a culpabilidade enquanto reprovabilidade está em crise, porque a seletividade do sistema penal é desprovida de conteúdo ético e, desta feita, não se pode construir a culpabilidade como reprovação sem um conteúdo ético e diante disso se faz necessário admitir que não seja possível formular um juízo de reprovação a um indivíduo do qual não era razoavelmente possível exigir que agisse de outra maneira, quando "seu âmbito de autodeterminação estava tão reduzido pelas circunstâncias objetivas que também a exigibilidade aparecia sumamente reduzida ${ }^{250}$,

Nesse sentido, todas as pessoas atuam em uma circunstância dada e dentro de uma esfera de autodeterminação também dada, entretanto, a sociedade, por mais bem organizada que seja, acaba não proporcionando a todos os seus membros, de forma uníssona, as oportunidades para seu desenvolvimento humano e social, alguns indivíduos mais vulneráveis restam condicionados por estas causas sociais adversas, possuindo, então menor capacidade de autodeterminação de suas condutas.

Assim, não se poderá atribuir estas causas sociais ao indivíduo, vindo a sobrecarregálo com elas no momento da reprovação da culpabilidade. Em contrapartida, a própria sociedade deve arcar com sua parcela de responsabilidade e daí se extrai a chamada teoria ou princípio da coculpabilidade.

Logo, o princípio da coculpabilidade ingressa no mundo do Direito Penal para identificar a parcela de responsabilidade que deve ser atribuída à sociedade e ao Estado quando da prática de determinadas infrações penais pelos seus cidadãos, quando estes sofreram menosprezo no acesso aos seus direitos fundamentais devido à omissão do Estado no âmbito social e da sociedade no que atine à obrigação constitucional de solidariedade de uns para com os outros.

\footnotetext{
${ }^{249}$ Idem.

${ }^{250}$ Idem, p. 259.
} 
Entretanto, o Estado e a sociedade não oferecem as mesmas oportunidades sociais a todos os cidadãos para que estes tenham as condições dignas necessárias para o seu desenvolvimento humano, de forma igualitária como preconizada na Constituição Federal.

A lógica que impera nas sociedades atuais é a da distribuição desigual de bens e de oportunidades entre os indivíduos ${ }^{251}$.

Nilo Batista ${ }^{252}$ também enfrenta a questão da operacionalidade do sistema penal e admite o que o caracteriza são a estigmação e a repressividade.

Este autor assevera que o sistema penal se apresenta sob o discurso de que atinge igualmente as pessoas em função de suas condutas, sendo assim considerado justo, na medida em que, teoricamente, busca prevenir o delito, tendo intervenção restrita às situações de premente necessidade. Entretanto, o desempenho do sistema penal é, em verdade, repressivo, tanto pela ótica da frustração de suas ideias preventivas, quanto pelo fato de estar atestada incapacidade de regular a intensidade das respostas penais. Desta feita, por trás do discurso do comprometimento com a proteção da dignidade humana, o sistema penal se revela estigmatizante, promovendo uma degradação na figura social de sua clientela ${ }^{253}$.

Salo de Carvalho argumenta que se o conteúdo da culpabilidade é fornecido pela ideia de autodeterminação e corresponde à capacidade de o indivíduo, nas circunstâncias fáticas, motivar-se conforme a norma, então, há de se admitir que o grau de instrução e cultura que a pessoa recebe influencia sensivelmente na cognoscibilidade do ilícito e na exigibilidade do comportamento que corresponde à movimentação positiva ou negativa do indivíduo em relação ao ato ${ }^{254}$.

Isso enseja que meio social exerce influência sobre a formação da personalidade humana e, assim, pode vir a comprometer o âmbito de autodeterminação ligado ao livre arbítrio de cada ser humano.

Nos apontamentos de Juarez Cirino dos $\operatorname{Santos}^{255}$, pode ser admitida a coculpabilidade da sociedade organizada como uma valoração acerca da responsabilidade de indivíduos inferiorizados por condições sociais adversas com o intuito de compensar a falha estatal na prestação igualitária dos direitos sociais que ocorreu em relação a estes.

\footnotetext{
${ }^{251}$ BARATTA, Alessandro. Op.cit., p. 106.

252 BATISTA, Nilo. Op.cit., p. 25.

${ }^{253}$ Idem, p. 25 e 26.

${ }^{254}$ CARVALHO, Salo de. Aplicação da pena e garantismo. 4.ed. Rio de Janeiro: Editora Lúmen Júris, 2008, p. 78.

${ }^{255}$ SANTOS, Juarez Cirino dos. Op.cit., p. 232.
} 
Evidentemente, esta noção de coculpabilidade não é aceita de forma pacífica, mas ao contrário, é alvo de críticas. Na posição de Eugenio Raul Zaffaroni, a principal crítica que este princípio recebe concerne ao equivocado pressuposto de que a criminalidade é efeito da pobreza, além de, também, se subestimar a seletividade criminalizante ínsita ao sistema penal $^{256}$.

Ao lado de Alejandro Alagia e Alejandro Slokar, o autor propõe a adoção de uma culpabilidade pela vulnerabilidade, que mantém o foco no sujeito de posição vulnerável e, por isso, mais propenso aos efeitos da criminalização por um sistema penal irracional e seletivo, ao invés de preocupar-se em responsabilizar a sociedade pela da criminalidade dos excluídos. Desta forma, a mensuração da reprovação do delito estaria relacionada à situação de vulnerabilidade do agente em vista da seletividade estrutural do sistema ${ }^{257}$.

Fato incontroverso é a seletividade do sistema penal que confere privilégios aos detentores de poder e exclui os necessitados; nesse cenário, percebe-se que a criação da lei penal se volta aos interesses das camadas sociais detentoras do poder e não, como deveria ocorrer, em prol da coletividade, haja vista existe uma desmedida distribuição de rótulos de criminosos pela população ${ }^{258}$.

A seletividade do sistema penal se deve à especificidade da infração e das conotações sociais dos autores, pois impunidade e criminalização se conduzem pela seleção desigual de pessoas de acordo com seu 'status' social e não pela incriminação igualitária de condutas objetivas e subjetivamente consideradas em relação ao fato-crime, conforme preconiza a teoria da dogmática penal ${ }^{259}$.

Zygmunt Bauman ${ }^{260}$ já dizia que as elites escolheram o isolamento e pagam por ele de forma espontânea, enquanto que o restante da população se vê distante dessa realidade e, por isso, acaba sendo levado a pagar o preço cultural, psicológico e político do seu novo isolamento.

Isso é resultado do processo de globalização que estreitou as distâncias e tornou de acesso comum o que antes era restrito.

Esse fenômeno apresenta a possibilidade de conhecimento mundial das violações a direitos humanos que antes passavam despercebidos pela maioria da população e, em

\footnotetext{
${ }^{256}$ ZAFFARONI, Eugenio Raúl; ALAGIA, Alejandro; SLOKAR, Alejandro. Derecho penal: parte general. 2. ed. Buenos Aires: Ediar, 2002, p. 650-657.

${ }^{257}$ Idem.

${ }^{258}$ BARATTA, Alessandro. Op.cit., p. 102.

${ }^{259}$ ANDRADE, Vera Regina Pereira de. A ilusão de segurança jurídica: do controle da violência à violência do controle penal. $2^{a}$ ed, Porto Alegre: Livraria do advogado, 2003, p. 51.

${ }^{260}$ BAUMAN, Zygmunt. Globalização: As conseqüências humanas. Rio de Janeiro: Jorge Zahar, 1999, p. 29.
} 
contrapartida, também possibilitou que se visualize certo retrocesso no cumprimento desses direitos, o que por razões consideradas ínfimas e de cunho econômico, próprio do mundo capitalista.

Diante disso, evidenciou-se a situação de miséria, o que levou à separação entre os homens e pelo que se depreende do cenário atual, são maiores os prejuízos sentidos por essa uniformização de costumes do que seus aspectos proveitosos ${ }^{261}$.

Nesse sentido, Michel Foucault entende que o poder produz domínio de objetos e rituais de verdade, eficácia, produtiva e riqueza estratégica. Entretanto, para que esse poder seja legitimado e internalizado por aqueles sobre os quais é exercido, deve circular continuamente, de forma ininterrupta, adaptada e individualizada no corpo social. Em virtude disso, o discurso faz-se essencial, uma vez que a ele cabe a busca da legitimação do sistema penal e a fundamentação de seu operar ${ }^{262}$.

Segundo Nilo Batista ${ }^{263}$, a realidade carcerária reflete a seletividade do sistema, a qual se origina do pensamento imposto pela sociedade capitalista de consumo que explora a máxima de que aquele que tem recursos não delinque, ao passo que se põe em dúvida a integridade daquele cidadão que não goza da mesma condição, isto porque este teria a propensão à delinquência como meio de evoluir na estratificação social, com a finalidade de lograr privilégios classistas próprios das elites dominantes. Embora seja um pensamento arcaico que leva a uma estigmatização da população de baixa renda.

Então, a liberdade dos indivíduos socialmente excluídos restaria comprometida. Esses cidadãos seriam "livres dentro de uma fatalidade dada", consoante citação de Ortega y Gasset feita por Juarez Cirino dos Santos ${ }^{264}$.

A aplicação do princípio da coculpabilidade torna-se um instrumento indispensável no reconhecimento da corresponsabilidade, por meio do qual se admite que o Estado falha na prestação dos direitos sociais e que a dignidade humana é um direito constitucional que assiste a todos. Pode-se dizer que seria, portanto, um reforçamento da dignidade humana no âmbito do Direito Penal.

Dos estudos de Alessandro Baratta, vislumbra-se que a definição legal distingue o que é uma conduta criminosa do que é uma conduta lícita, pouco importando o fato de se o

\footnotetext{
${ }^{261}$ BAUMAN, Zygmunt. Op. Cit. p. 67.

${ }^{262}$ FOUCAULT, Michel. Microfísica do poder. 15. ed. Rio de Janeiro: Graal, 2000, p. 12.

${ }^{263}$ BATISTA, Nilo. Op.cit., p. 26.

${ }^{264}$ SANTOS, Juarez Cirino dos. Op.cit., p. 231.
} 
agente teve uma postura interior boa ou má, social ou antissocial, bem como o juízo de valor que os demais membros do corpo social realizarão a este respeito ${ }^{265}$.

Este autor enfatiza que a base do comportamento considerado como desviante se calca na desproporção existente entre os fins reconhecidos como válidos do ponto de vista cultural de uma determinada sociedade e os meios que o grupo considera legítimos e coloca à disposição do indivíduo para alcançá-los ${ }^{266}$.

A coculpabilidade tende a transpor o abismo existente entre a teoria e a realidade, que se estuda e que se vive respectivamente, do sistema e do processo penal. A condenação deve ser o mais condizente possível com a realidade e com as circunstâncias fáticas.

Reconhecendo todas essas especificidades, o princípio da coculpabilidade incide atribuindo a responsabilidade ao Estado pelo descumprimento das normas constitucionais de atender a todos com a execução dos direitos sociais e à sociedade pelo etiquetamento e segregação de determinadas pessoas, impossibilitando-as de se engajar no grupo; bem como, reconhece no agente a diminuição do poder de autodeterminação ${ }^{267}$.

Isso reforça a busca pelo Direito Penal Mínimo, consignando em "ultima ratio" a aplicabilidade desse ramo do direito que é, por sua natureza, o mais incisivo na vida das pessoas.

Ora, se por tal princípio se pode diminuir a pena do sujeito, então, mais freqüentes serão os casos de substituição da pena privativa de liberdade, mais facilmente os presos preencherão os requisitos objetivos para o pleito de direitos na fase de execução penal, mais rapidamente ocorrerá prescrição da pretensão executória da pena e, em determinados casos, o Estado sequer precisará intervir com o Direito Penal ${ }^{268}$.

\section{4 - Embasamento constitucional do princípio da coculpabilidade}

Grégore Moura $^{269}$ estudou o princípio da coculpabilidade e concluiu que este seria um princípio constitucional implícito, que se atrela às noções da igualdade, da dignidade humana e da individualização da pena.

O primeiro artigo da Constituição Federal brasileira revela a dignidade da pessoa humana como fundamento da República ${ }^{270}$; isto significa que Estado e sociedade têm a pessoa como foco.

\footnotetext{
${ }^{265}$ BARATTA, Alessandro. Op.cit., p. 85-86.

${ }^{266}$ Idem, p. 63.

${ }^{267}$ MOURA, Grégore Moreira de. Op.cit., p. 109.

${ }^{268}$ Idem, p. 111.

${ }^{269}$ MOURA, Grégore Moreira de. Do princípio da co-culpabilidade. Niterói, Rio de Janeiro: Impetus, 2006.
} 
Ao dispor sobre os objetivos da República Federativa do Brasil, a Magna Carta pátria confere primazia ao cidadão, demonstrando que as políticas públicas devem ter por foco a consecução do bem comum e a constante busca da igualdade ${ }^{271}$.

Segundo Helena Regina Lobo da $\operatorname{Costa}^{272}$, a dignidade da pessoa humana é que consubstancia os direitos fundamentais; é nela que o Estado encontra legitimidade para seus atos, principalmente no que tange ao "jus puniendi".

Grégore Moura $^{273}$ assevera ser a dignidade humana um valor supremo que norteia todo o ordenamento jurídico nacional e cabe aos três poderes ${ }^{274}$ a ação de tal princípio no mundo fenomênico.Cumprindo-se a premissa da dignidade humana, restaria satisfeita, por conseguinte, a questão da igualdade.

Ao doutrinar sobre o direito constitucional da igualdade, que a Constituição Federal de 1988 consagra como princípio, José Afonso da Silva ${ }^{275}$ escreve que "porque existem desigualdades, é que se aspira à igualdade real ou material que busque realizar a igualização das condições desiguais".

No âmbito dessa questão da igualdade, verifica-se que o sistema penal torna-se seletivo. Neste sentido, Luigi Ferrajoli distingue igualdade política de igualdade social, suscitando que o princípio da igualdade não é uma tese descritiva, mas um princípio normativo, ou seja, um valor de cunho constitucional que reconhece que os homens são diferentes. De tal sorte, reconhecem-se diversidades de sexo, de raça, de língua, de religião, de opinião política, enfim, diferenças pessoais. Contudo, sob o enfoque da igualdade em aspecto substancial, tem-se que as pessoas são social e economicamente desiguais $^{276}$.

\footnotetext{
${ }^{270}$ Artigo $1^{\circ}$ da Constituição da República Federativa do Brasil, 1988. A República Federativa do Brasil, formada pela união indissolúvel dos Estados e Municípios e do Distrito Federal, constitui-se em Estado Democrático de Direito e tem como fundamentos: III - a dignidade da pessoa humana.

${ }^{271}$ Artigo $3^{\circ}$ da Constituição da República Federativa do Brasil, 1988. Constituem objetivos fundamentais da República Federativa do Brasil: I - construir uma sociedade livre, justa e solidária; II - garantir o desenvolvimento nacional; III - erradicar a pobreza e a marginalização e reduzir as desigualdades sociais e regionais; IV - promover o bem de todos, sem preconceitos de origem, raça, sexo, cor, idade e quaisquer outras formas de discriminação.

${ }^{272}$ COSTA, Helena Regina Lobo da. A dignidade humana: teorias de prevenção geral positiva. São Paulo: Revista dosTribunais, 2008, p. 37.

${ }^{273}$ MOURA, Grégore Moreira de. Op.cit., p. 61.

${ }^{274}$ Artigo $2^{\circ}$ da Constituição da República Federativa do Brasil, 1988. São Poderes da União, independentes e harmônicos entre si, o Legislativo, o Executivo e o Judiciário.

${ }^{275}$ SILVA, José Afonso da. Op.cit., p.212-213.

${ }^{276}$ FERRAJOLI, Luigi. Direito e razão: teoria do garantismo penal. Tradução de Ana Paula Zomer. São Paulo: Editora Revista dos Tribunais, 2002, p. 726-727.
} 
José Afonso da Silva expõe a igualdade como signo fundamental da democracia e justifica que a burguesia nunca postulou um regime de igualdade tal como fez em relação à liberdade, porque um regime de igualdade constrastaria seus interesses ${ }^{277}$.

Nesta mesma linha de pensamento, Grégore Moura enfatiza que "como o direito é feito pelos 'detentores do poder econômico e social' e estes são fervorosos defensores da desigualdade, por meio deste instrumento de controle social, infelizmente, nunca atingiremos a almejada igualdade material ${ }^{278, "}$.

É possível relacionar a ideia de igualdade real com o conceito de coculpabilidade, uma vez que, segundo este princípio, valora-se a conduta do individuo socialmente desfavorecido de forma diferente da que se atribui o juízo de reprovação em razão à conduta daquele que ocupou uma posição social privilegiada ou que simplesmente recebeu do Estado a prestação dos direitos sociais de maneira satisfatória.

Segundo ensina José Joaquim Gomes Canotilho ${ }^{279}$, embora a Constituição Federal tenha por premissa o princípio da igualdade, este precisa ser visto como princípio dinâmico, impositivo da igualdade material e voltado à consecução desta, o que implica a compensação positiva das desigualdades de oportunidades.

A lição de John Rawls parte do pressuposto que, abaixo de certo nível de bem-estar material e social, de educação, as pessoas restam impedidas de participar da sociedade como cidadãos, e muito menos como cidadãos iguais ${ }^{280}$. De tal assertiva se conclui que as desigualdades sociais culminam em desigualdades perante a lei.

A doutrina de Norberto Bobbio explicita que o objetivo do princípio da igualdade das oportunidades é colocar em posições iguais todos os membros de determinada sociedade, no que tange a participar ativamente da vida do grupo, sendo, por conseguinte, supérfluo considerar que varia de sociedade para sociedade a definição de quais devem ser as posições de partida a serem consideradas como iguais, de quais devam ser as condições sociais e materiais que permitam considerar os concorrentes iguais ${ }^{281}$.

Ainda segundo se depreende dos referidos ensinamentos de Norberto Bobbio, vislumbra-se que a questão de colocar indivíduos desiguais por nascimento nas mesmas

\footnotetext{
${ }^{277}$ SILVA, José Afonso da. Op.cit., p. 210.

${ }^{278}$ MOURA, Grégore Moreira de. Do princípio da co-culpabilidade. Niterói, Rio de Janeiro: Impetus, 2006, p. 59.

${ }^{279}$ CANOTILHO, José Joaquim Gomes. Direito constitucional e teoria da constituição. Coimbra: Almedina, 1998 , p. 332.

${ }^{280}$ RAWS, John. Teoría de la justicia. Tradução: Maria Dolores González. México: Fondo de Cultura Economica, 1993, p. 213.

${ }^{281}$ BOBBIO, Norberto. Igualdade e liberdade. 4. ed. Rio de Janeiro: Ediouro, 2000, p. 31-32.
} 
condições de partida implica favorecer os mais pobres e desfavorecer os mais ricos, o que torna uma desigualdade instrumento de igualdade, corrigindo uma desigualdade anterior, ou seja, se obtém a igualdade equiparando duas desigualdades ${ }^{282}$.

$\mathrm{O}$ autor ${ }^{283}$ lança perguntas que corroboram essa explicação, demonstrando como as desigualdades devem ser enfrentadas: é suficiente o livre acesso às escolas iguais? Mas a que escolas, de que nível, até que ano de idade? Já que se chega à escola a partir da vida familiar, não será preciso equalizar também as condições de família nas quais cada um vive desde o nascimento?

Desta feita, impõe-se ao Estado uma parcela de responsabilidade, diminuindo a do cidadão que esteve colocado às margens da sociedade e, por isso, passou despercebido pela

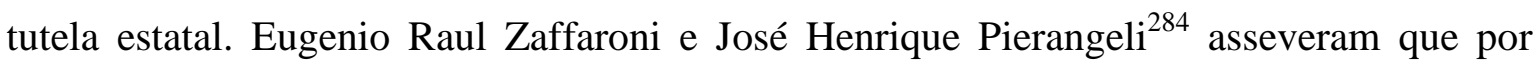
mais bem organizada que seja uma determinada sociedade, não se brinda a todos os indivíduos com as mesmas oportunidades, maculando, portanto, o desenvolvimento humano e social de uma classe de pessoas e comprometendo, desta sua capacidade de autodeterminação em relação a suas condutas.

Isto não significa que o princípio da coculpabilidade iguale o direito de liberdade do indivíduo com o "jus puniendi" do Estado; o princípio em estudo reconhece a ineficiência do Estado na promoção da dignidade humana, da igualdade e do bem comum, reconhece ainda o infrator como sujeito de direitos ${ }^{285} \mathrm{e}$, diante disso, tem por escopo minimizar os efeitos da exclusão social que decorrem, como cediço, das inúmeras desigualdades de oportunidades.

Da obra em que Luigi Ferrajoli apresenta o garantismo penal depreende-se que o sistema garantista proposto pelo autor tem por escopo diminuir as incertezas que permeiam o processo penal; desde a análise dos fatos até o momento em que se vai atribuir uma pena ao autor de um delito, há de se observar as garantias para que o sistema e o processo penal sejam mais coerentes com a realidade ${ }^{286}$.

O Estado, ao não conseguir evitar a exclusão social, deixa de cumprir a Constituição Federal em seus objetivos e em seus princípios basilares, comprometendo, assim, a credibilidade em todo o sistema de garantias.

\footnotetext{
${ }^{282}$ Idem.

${ }^{283}$ Idem.

${ }^{284}$ ZAFFARONI, Eugenio Raul; PIERANGELI, José Henrique. Op.cit, p. 611.

${ }^{285}$ Com o advento do período humanitário das penas, os estudos realizados sobre o criminoso deixam de tratá-lo como objeto da ciência, reconhecendo-o como sujeito. BITENCOUT, Cezar Roberto. Manual de Direito Penal: parte geral. 7.ed. São Paulo: Saraiva, 2002, p. 31-40.

${ }^{286}$ FERRAJOLI. Luigi. Direito e razão: teoria do garantismo penal. Tradução de Ana Paula Zomer et.al. São Paulo: Editora Revista dos Tribunais, 2002, p. 87.
} 
O princípio da coculpabilidade confere praticidade também ao princípio constitucional da individualização da pena ${ }^{287}$. Este princípio impõe que a pena atribuída ao fato criminoso se faça necessária e suficiente para a reprovação do crime ${ }^{288}$.

No momento da individualização da pena, é necessário que se reconheça a pessoa concreta à qual a pena se destina. E, nesse momento, imprescindível que se considerem todos os fundamentos do Princípio da coculpabilidade, como ressalta Nilo Batista: "trata-se de considerar, no juízo de reprovabilidade, que é a essência da culpabilidade, a concreta experiência social dos réus, as oportunidades que se lhes depararam e a assistência que lhes foi ministrada, correlacionando sua própria responsabilidade a uma responsabilidade geral do Estado que vai impor-lhe a pena; em certa medida, a co-culpabilidade faz sentar no banco dos réus, ao lado dos mesmos réus, a sociedade que os produziu" ${ }^{289}$.

Se o cidadão que comete um delito torna-se, por sua conduta ilícita, devedor do Estado, por outro lado, o Estado é devedor do cidadão ao passo que a Constituição Federal lhe obriga a oferecer igualmente a todos os direitos sociais dos quais necessitam para o desenvolvimento humano e ele não consegue abarcar a todos em seus serviços essenciais.

Desta feita, o princípio da coculpabilidade tem a aptidão de proporcionar ao juiz a possibilidade de declarar, na sentença, que o sistema penal reconhece a liberdade limitada desta parcela da sociedade e que a responsabilidade pela adoção de uma "conduta desviante" deve ser dividida entre aquele infrator e os demais membros da sociedade que, se não o jogaram às margens do grupo, também não o inseriram como membro útil à vida social.

Porém, ao interpretar o princípio da coculpabilidade, principalmente no tocante a estabelecer a referida igualdade material através da individualização da pena, partia-se de pressupostos que se revelaram equivocados, por exemplo, da ideia que a criminalidade é efeito da pobreza e pouco se falava da seletividade criminalizante ${ }^{290}$, assunto este que já foi

\footnotetext{
${ }^{287}$ Art. $5^{\circ}$, inciso XLVI da Constituição da República Federativa do Brasil, 1988 - a lei regulará a individualização da pena e adotará, entre outras, as seguintes: a) privação ou restrição de liberdade; b) perda de bens; c) multa; d) prestação social alternativa; e) suspensão ou interdição de direitos.

${ }^{288}$ Art. 59 do Código Penal brasileiro. O juiz, atendendo à culpabilidade, aos antecedentes, à conduta social, à personalidade do agente, aos motivos, às circunstâncias e às consequências do crime, bem como ao comportamento da vítima, estabelecerá, conforme seja necessário e suficiente para reprovação e prevenção do crime: I-as penas aplicáveis dentre as cominadas; II- a quantidade de pena aplicável dentro dos limites previstos; III-o regime inicial do cumprimento da pena privativa de liberdade; IV-a substituição da pena privativa de liberdade aplicada, por outra espécie de pena, se cabível.

${ }^{289}$ BATISTA, Nilo. Op.cit., p. 105.

${ }^{290}$ Idem, p. 83-84.
} 
abordado no tópico anterior quando se analisou as teorias criminológicas que fundamentam o princípio em estudo.

\section{5 - Localização do Princípio da coculpabilidade no Direito Penal}

Viu-se no capítulo anterior a dimensão da estrutura da culpabilidade e a sua importância. Enquanto o princípio da culpabilidade limita o poder de punir ao vedar a responsabilização objetiva, a culpabilidade como elemento da dogmática penal pertencente à teoria do delito analisa o juízo de reprovação da conduta praticada.

Falar que a coculpabilidade decorre da culpabilidade é quase um pleonasmo; contudo, diante das acepções estudadas acerca da culpabilidade e a fim de dar sequencia no presente estudo, cumpre localizar em qual dos aspectos o aplicador do Direito se foca para analisar a coculpabilidade.

Em verdade, a amplitude do princípio da coculpabilidade é tão perceptível que se pode responder a indagação acima da seguinte maneira: em todos os aspectos da culpabilidade se pode analisar a corresponsabilidade.

Murray Sidman esclarece que o ambiente social condiciona o comportamento humano. A crítica de referido analista do comportamento se fundamenta "porque um grande segmento da sociedade tem sido bem sucedido em superar os estresses externos e internos que o ambiente natural impõe, muitos de nós perdemos de vista a extensão na qual a natureza modela coercitivamente nossa conduta ${ }^{291}$,.

Segundo Eugenio Raúl Zaffaroni, Alejandro Alagia, e Alejandro Slokar, a noção de coculpabilidade se funda na constatação de que o juízo de reprovação penal deve adequarse ao espaço social que foi conferido ao indivíduo, já que nenhuma sociedade apresenta mobilidade vertical ao ponto de oportunizar a todos os seus integrantes o mesmo espaço social $^{292}$.

Como conceito possível acerca do princípio da coculpabilidade tem-se que se trata de um princípio do direito penal, empregado juntamente com a culpabilidade no momento da verificação da necessidade de se atribuir pena a um infrator, por meio do qual se reconhece a existência de uma responsabilidade parcial do Estado e da sociedade na conduta delitiva, devido ao fato de que a sociedade não atribui a todos as mesmas possibilidades de ação

\footnotetext{
${ }^{291}$ SIDMAN, Murray. Op.cit., p. 36.

${ }^{292}$ ZAFFARONI, Eugenio Raúl; ALAGIA, Alejandro; SLOKAR, Alejandro. Derecho penal: parte general.

2. ed. Buenos Aires: Ediar, 2002, p. 656.
} 
dentro da legalidade imposta e, em decorrência disso, alguns indivíduos que vivem em condições desumanas, tornam-se mais vulneráveis às influências do meio.

Pelo conceito da coculpabilidade, todo o seu conteúdo e demonstrada sua vertente constitucional, vislumbra-se se tratar de um princípio e, como princípio, cabe ao ordenamento jurídico respeitar tal importância.

Partindo esta análise da culpabilidade como elemento integrante do conceito de crime e tendo visto no capítulo anterior os requisitos que a constituem (imputabilidade, potencial consciência da ilicitude e exigibilidade de obediência ao Direito), é possível pensar que, para se reconhecer a existência de uma corresponsabilidade do Estado e da sociedade, não basta que o indivíduo seja pobre, mas é necessário que um dos elementos que constituem sua culpabilidade se apresente modificado pela influência recebida.

O primeiro requisito é a imputabilidade. Como visto, seu significado é trazido pela lei, no tex to do artigo 26 do Código Penal (que define quem são os inimputáveis) e implica na capacidade de autodeterminação, ou seja, de entender o caráter ilícito do fato e nortear seu comportamento de acordo com este entendimento.

Como a lei estreita os casos em que a imputabilidade do agente resta afetada, e a noção já exposta da coculpabilidade é clara no sentido de que o fato de a pessoa viver em condições socioeconômicas adversas não afeta sua capacidade de autodeterminação em relação ao que considera certo ou errado, constata-se que não será a imputabilidade a restar comprometida.

Importa observar que, embora a coculpabilidade analise o crime sob seu aspecto social, não pode ser confundida com a teoria da responsabilidade social de Enrico Ferri que se calca no determinismo social. Para esta teoria, a norma jurídica seria dirigida a todas as pessoas, fossem elas normais ou anormais, e o fato de se viver em sociedade gera para o indivíduo a obrigação de se submeter às regras. Porém, o que designava uma pessoa como delinquente não eram suas características fisiopsíquicas como sustentava Cesare Lombroso, mas o lugar que ela ocupa dentro da sociedade ${ }^{293}$.

Segundo Enrico Ferri, a sociedade propicia proteção ao homem, bem como lhe oferta meios para seu desenvolvimento moral, intelectual e físico, por essa razão, o homem deve suportar as regras, as sanções e as limitações que asseguram disciplina dentro do grupo, pois sem isso não seria possível conviver nem se desenvolver ${ }^{294}$.

${ }^{293}$ FERRI, Enrico. Princípios de Direito Criminal: o criminoso e o crime. 2.ed. Campinas: Bookseller, 2003, p. 232.

${ }^{294}$ Idem. 
Evidencia-se que na teoria da responsabilidade social a preocupação não é com o ser humano, mas com a sociedade e o respeito às suas leis. Como o homem deve respeito, por gratidão, ao que a sociedade lhe deu, o fato de infringir as normas de convivência revela-se odioso. O que se preconiza é a defesa social dos direitos do Estado.

Diferentemente, a coculpabilidade protege os direitos individuais fundamentais do ser humano perante o Estado quando este não cumpre os deveres que a Constituição Federal lhe impõe; também, direciona-se precipuamente à questão da pena e não a perquirir a relação que o homem tem com as normas jurídicas.

Frisa-se ainda que a coculpabilidade não questiona o livre arbítrio, nem se há ou se deixa de haver vontade por parte do agente ao cometer o crime ou se a vontade é predeterminada (qualquer que seja a razão do determinismo), porque essa análise se refere ao dolo que, por sua vez, é elemento que interessa quando se estuda tipicidade e não culpabilidade.

Retomando a análise dos elementos da culpabilidade, passa-se a considerar o segundo, qual seja, a potencial consciência da ilicitude.

Segundo Luís Augusto Sanzo Brodt, consciência da ilicitude é a capacidade de o indivíduo vir a conhecer que o fato que está praticando é um comportamento ilícito. Se presente, autoriza a reprovação; se ausente, terá o agente incorrido em erro sobre a ilicitude ${ }^{295}$.

Esse requisito é mais objetivo que o primeiro, pois ele se ocupa da possibilidade de o agente tomar conhecimento de que aquele determinado comportamento é definido por lei como crime. Teoricamente, todas as pessoas que tenham acesso, de algum modo, à legislação ou a meios de comunicação e informação, podem adquirir essa consciência.

Contudo, se o Estado torna-se inadimplente em relação aos cidadãos por não conseguir efetivar os direitos sociais básicos, constitucionalmente previstos, tampouco conseguirá levar à toda a população o conhecimento das normas jurídicas, tanto porque seria um contrassenso se a pessoa excluída que não tem acesso à educação, à saúde, à moradia, tivesse acesso aos meios institucionais ${ }^{296}$.

Em seus estudos, Carlos María Cárcova enaltece que as classes marginalizadas, socialmente excluídas, são as que sofrem o prejuízo maior pelo desconhecimento do

\footnotetext{
${ }^{295}$ BRODT, Luís Augusto Sanzo. Da consciência da ilicitude no Direito Penal brasileiro. Belo Horizonte: Del Rey, 1996, p. 17.

${ }^{296}$ SHRAPPE, Allana Campos Marques. Apud MOURA, Grégore Moreira de. Op.cit., p. 54.
} 
direito; o autor corrobora ainda as considerações já feitas acerca de que, nas sociedades modernas, o consumo se revela fator determinante da inclusão e da exclusão social ${ }^{297}$.

Diante disso, sendo a potencial consciência da ilicitude um dos requisitos para que seja reconhecida a culpabilidade e sendo a culpabilidade, além de elemento constitutivo do conceito crime, medida e limite da pena, repousa aí o fundamento para se diminuir a reprovação penal, afinal, aonde não chega o Estado nem a solidariedade social, dificilmente chegará o acesso ao Direito ou aos meios institucionais (como denominou Merton).

Embora já se vislumbrando que o princípio da coculpabilidade, se reconhecido, pode afetar a potencial consciência da ilicitude, vale analisar o terceiro requisito da culpabilidade, a exigibilidade de obediência ao Direito.

$\mathrm{O}$ artigo $6^{\circ}$ da Constituição Federal elenca os direitos sociais do cidadão que se configuram em dever do Estado, pois o obrigam a uma incontestável prestação de serviços públicos basilares à vida da população ${ }^{298}$.

Diante de tal mandamento constitucional, pergunta-se: como exigir que determinada pessoa obedecesse ao Direito se o próprio Estado, quando tinha de zelar por esta pessoa propiciando as mínimas condições de desenvolvimento, obedecendo a Lei Maior de todo o Direito, não o fez?

Singular é a importância que têm os direitos fundamentais, conforme será esboçado a seguir.

Um dos princípios basilares que vige no Estado Democrático de Direito é o da legalidade. Segundo Christian $\operatorname{Starck}^{299}$, a lei precisa influir na realidade social e, assim, propiciar os ajustes necessários na situação da comunidade para atingir os objetivos trazidos pela Constituição.

Do conceito de Estado Democrático de Direito identifica-se três elementos que o constituem, quais sejam, existência de leis que representam a vontade da maioria, não podendo tangenciar as liberdades fundamentais das minorias; a primazia conferida aos indivíduos pela operação estatal e a aplicação da lei geral e abstrata por juízes independentes $^{300}$.

\footnotetext{
${ }^{297}$ CÁRCOVA, Carlos María. La opacidad del derecho Madrid: Trotta, 1998, p. 59.

298 Art. $6^{\circ}$ da Constituição da República Federativa do Brasil, 1988 - São direitos sociais a educação, a saúde, a alimentação, o trabalho, a moradia, o lazer, a segurança, a previdência social, a proteção à maternidade e à infância, a assistência aos desamparados, na forma desta Constituição.

${ }^{299}$ STARCK, Christian. El concepto de ley em la constituición alemana. Madrid, Centro de Estudios Constitucionales, 1979, p. 300.

${ }^{300}$ JUNQUEIRA, Gustavo Octaviano Diniz. Finalidades da Pena. Editora Manole, p. 8.
} 
Lenio Streck $^{301}$ assevera que as garantias, tanto sociais quanto liberais, expressam os direitos fundamentais do cidadão frente aos poderes do Estado e tem o condão de tutelar a questão da marginalização que atinge as minorias e as separa da maioria da sociedade integrada.

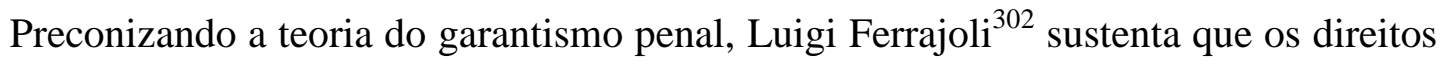
fundamentais, revestidos dos caracteres da indisponibilidade e da inviolabilidade por serem de natureza personalíssima, correspondem à forma jurídica positivada dos direitos naturais e têm como garantia o fundamento político ou externo do moderno Estado de Direito, o que possibilita que as disposições contrárias aos direitos fundamentais sejam anuladas.

Essa coobrigação entre Estado e sociedade é possível se extrair do próprio conceito de República. José Afonso da Silva ${ }^{303}$ diz que o vocábulo República se refere a uma determinada forma de governo, designando uma coletividade política com características da res publica, ou seja, da coisa do povo e para o povo e corrobora suas explicações fazendo menção a Aristóteles, segundo quem República é a forma de governo na qual o povo governa no interesse do povo.

Tudo isso possibilita o entendimento de que, na atribuição da corresponsabilidade, que se dá pelo reconhecimento do princípio da coculpabilidade, se, em determinado caso não for afastada a potencial consciência da ilicitude, há de se analisar também, de acordo com a situação fática de acesso que aquele delinquente teve aos direitos sociais, era possível, cabível, exigir-lhe que obedecesse ao Direito, Direito que lhe foi negado por quem deveria assegura-lo.

Ademais, seria razoável, do ponto de vista humano e jurídico, cogitar-se a exigibilidade de conduta diversa de indivíduos que se encontram em uma situação perene de segregação social e miséria?

Pode-se exigir de um ser humano cuja existência não se reveste de dignidade alguma ao passar frio, fome e se ver alheio aos direitos básicos de pessoa humana, que tenha a mesma aptidão de condutas que uma pessoa que sempre teve uma condição material de vida suficiente para viabilizar seu desenvolvimento?

\footnotetext{
${ }^{301}$ STRECK, Lenio. O trabalho dos juristas na perspectiva do Estado Democrático de Direito: da utilidade de uma crítica garantista. Rio de Janeiro, 1996, p. 44.

${ }^{302}$ FERRAJOLI, Luigi. Derecho y razión: teoría del garantismo penal. Editorial Trotta, 1995, p. 356.

${ }^{303}$ SILVA, José Afonso da. Op.cit., p. 102
} 
A ideia transparecida pelo conceito de Estado Democrático de Direito, conforme já analisado anteriormente, reflete-se no sentido de que o ente estatal se vincula à finalidade de promover a transformação da sociedade para o bem de todos ${ }^{304}$.

É cumprindo seus deveres constitucionais que o Estado concede a todos a concreção dos direitos básicos de cidadão e transforma a sociedade, reduzindo as desigualdades e promovendo o bem comum.

Analisada a relação da corresponsabilidade com a culpabilidade enquanto elemento do crime cumpre agora fazê-lo em relação à culpabilidade como limite e medida de pena, partindo do pressuposto óbvio que esta nova análise somente será feita se, no caso concreto, não se vislumbrar a incidência da coculpabilidade na potencial consciência da ilicitude nem na exigibilidade de obediência ao Direito, porque, se ela afetar um dos requisitos constitutivos da culpabilidade, excluirá a culpabilidade e consequentemente o crime e o agente não será penalizado.

A situação social do infrator há que ser considerada no momento da aplicação da pena, devendo-se atentar que a educação e boas condições de vida proporcionam maior equilíbrio emocional, assim como formação saudável da integridade física e mental, restando o ser humano preservado do descumprimento das regras sociais que o levariam ao crime $^{305}$.

Guilherme de Souza Nucci ${ }^{306}$ entende que ao sofrer privação de toda ordem, principalmente no que tange à sua própria sobrevivência, a pessoa tem maior propensão a infringir os padrões de condutas que se exige, vindo a cometer delitos. Isto porque a sociedade cria ambientes propícios ao despertar das condutas violentas, conforme o grau de competitividade e demais fatores econômicos, terminando por inserir grupos de pessoas na marginalidade social.

Ao analisar o princípio da culpabilidade, restou evidente sua função de limitar o direito de punir do Estado e vedar a responsabilidade penal objetiva.

Entendendo-o como limitação do "jus puniendi" do Estado e se considerando o conceito de coculpabilidade como a corresponsabilidade que sociedade e Estado têm ante a ocorrência de um crime cometido por uma pessoa que foi toda a vida excluída do grupo (pela sociedade) e da concreção de seus direitos sociais (pelo Estado), então, vislumbra-se

\footnotetext{
${ }^{304}$ SANTOS, Sérgio Roberto Leal dos. Manual de Teoria da Constituição. São Paulo: Revista dos Tribunais, 2008 , p. 57.

${ }^{305}$ NUCCI, Guilherme de Souza. Op.cit. ,p. 183 e 184.

${ }^{306}$ Idem.
} 
que a coculpabilidade também limita o direito de punir quando, em seu conteúdo, obriga o julgador a considerar as condições socioeconômicas do réu no contexto fático do delito.

Essa ideia também reforça a subjetivação da responsabilidade criminal, uma vez que exige que a atenção do juiz se volte ao autor do fato de um modo mais direcionado, individualizado, para se lograr a pena adequada àquele caso específico.

E a pessoa será punida na medida da sua culpabilidade. Se a culpabilidade pode ser reduzida por alguma das causas legais ou supralegais que a afetam e se a coculpabilidade pode reduzir a responsabilidade criminal do indivíduo, dividindo-a com a sociedade e com o Estado, então, esse princípio também deverá ser usado para a medida da pena; aliás, é neste sentido que a grande parte dos estudiosos da coculpabilidade a compreendem.

Cláudio Alberto Gabriel Guimarães, ao escrever o artigo intitulado “A culpabilidade compartilhada como princípio mitigador da ausência de efetivação dos direitos humanos fundamentais", sustenta que para que Estado possa punir de forma justa e legítima, necessário se faz que todos os cidadãos tenham tido, no ponto de partida, as mesmas oportunidades. E enfatiza que onde há mais incidência do Direito Punitivo, há menos prevalência dos Direitos Humanos sociais básicos ${ }^{307}$.

A proposta de Guimarães vem no seguinte sentido: “o Estado, representado pelo órgão jurisdicional e pelo Ministério Publico, reconhecendo não ter tido o apenado acesso aos direitos sociais mínimos que garantiriam a sua dignidade enquanto pessoa humana deixará de aplicar a pena e encaminhará o apenado para programas públicos de inclusão social, para que assim, o primeiro contato entre o Estado e o cidadão, se dê no âmbito da cidadania positiva, reconhecedora de direitos, e não na esfera da punição, da cidadania negativa, cujo objetivo é uma restrição ainda maior dos poucos direitos usufruídos pelos extremófilos" 308 .

Disso o autor conclui que a "mea culpa" que o princípio em análise propõe tem como principal objetivo atenuar o direito de punir do Estado pela omissão que o próprio Estado revelou ao não conseguir cumprir as leis que a Constituição Federal impôs como seu dever.

Nota-se a presença da ideia da contraprestação entre Estado e cidadão infrator como fundamento de quem localiza a coculpabilidade como fator que limita o "jus puniendi", e a justificativa amparada em todo aquele arcabouço de argumentos constitucionais acerca dos direitos sociais.

${ }^{307}$ GUIMARÃES, Cláudio Alberto Gabriel. A culpabilidade compartilhada como princípio mitigador da ausência de efetivação dos direitos humanos fundamentais. In: Novos Estudos Jurídicos, vol.3, n. 14, 2009, p. 153.

${ }^{308}$ Idem, p. 159. 
Ante o clamor de segurança social o que o Estado oferece é segurança criminal; assim, delineia-se a incapacidade do próprio Estado para zelar como se deve pelo âmbito social e, em consequência, atrofia-se também o sistema penal, de forma que a miséria e a extinção de um têm como contrapartida direta e necessária a grandeza e a prosperidade insolente do outro ${ }^{309}$.

Mas como já mencionado, a maioria dos autores que se manifestam sobre o tema 'coculpabilidade' a localizam no Direito Penal como circunstância atenuante que influenciará na medida da pena.

O amparo legal para os adeptos dessa vertente é o artigo 66 do Código Penal ${ }^{310}$, porém, esse assunto será abordado no próximo capítulo deste trabalho, no qual se estudará as possibilidades de inclusão da coculpabilidade no ordenamento jurídico pátrio.

Por ora, insta frisar que, se vista como circunstância atenuante, será usada, nos termos do artigo 68 do Código Penal ${ }^{311}$, na segunda fase da fixação da pena.

Vale uma crítica inicial a esta posição, pois, tendo visto as dimensões do princípio do coculpabilidade, coloca-lo como mera atenuante genérica, que incidirá em uma fase da dosimetria na qual a pena não fica aquém do mínimo legal, seria negar-lhe aplicabilidade prática.

Contudo, reitera-se que tais pormenores de aplicabilidade do princípio serão analisados no próximo capítulo, assim sendo, aqui cumpre informar que existe também o entendimento de que a coculpabilidade se situa no Direito Penal ainda como medida da pena.

Isso leva à conclusão que é possível situar a coculpabilidade com o mesmo alcance e importância da culpabilidade no âmbito do Direito Penal, podendo influir tanto para limitar o direito de punir do Estado, quanto na dosimetria da pena, se não for o caso de ela ensejar a exclusão da culpabilidade e, consequentemente, do crime.

\section{6 - O princípio da coculpabilidade no Direito Comparado}

Embora alguns tribunais brasileiros já tenham se deparado com a questão da aplicabilidade do princípio da coculpabilidade, esse assunto não é novidade em outros

\footnotetext{
${ }^{309}$ WACQUANT, Loïc. As Prisões da Miséria. Rio de Janeiro: Jorge Zahar Editor, 2001, p. 80.

${ }^{310}$ Art. 66 do Código Penal Brasileiro. A pena poderá ser ainda atenuada em razão de circunstância relevante, anterior ou posterior ao crime, embora não prevista expressamente em lei.

${ }^{311}$ Art. 68 do Código Penal Brasileiro. A pena-base será fixada atendendo-se ao critério do art. 59 deste Código; em seguida serão consideradas as circunstâncias atenuantes e agravantes; por último, as causas de diminuição e de aumento.
} 
países da América Latina. As legislações de Argentina, Peru, México, Colômbia, Equador e Bolívia já recepcionam referido princípio.

A legislação penal da América Latina possui caráter fortemente repressivo, o que reflete a crise generalizada que hoje se abate sobre o direito penal e evidencia a inadequação às realidades nacionais. Nessa parte do mundo, o fenômeno da criminalidade se relaciona diretamente com as condições de uma estrutura social injusta e desigual que oprime as classes mais baixas. $\mathrm{Na}$ tentativa de se resolver os problemas sociais, o legislador se vale do instrumental punitivo. Legisladores de muitos países da América Latina se inspiraram na lei espanhola de 1933, com a qual se pretende reprimir a periculosidade pré-delitual através da aplicação de medidas privativas de liberdade (que, em alguns casos, podem ir até cinco anos), por autoridades policiais ou administrativas ${ }^{312}$.

Nesse sentido se encaixa a preocupação de Loïc Wacquant ${ }^{313}$ quando afirma que, diante das disparidades econômicas entre as classes e da pouca tradição democrática, as políticas de segurança que se baseiam no modelo neoliberal e apresentam restrições às garantias penais juntamente com propostas de incremento no rol de crimes e de penas são mais sedutoras, pois são vistas como a solução rápida e eficaz para se resolver os problemas das comunidades mais pobres.

Como foi na Argentina que se desenvolveu a ideia originária do princípio da coculpabilidade, cumpre analisar primeiramente como o instituto é tratado no Código Penal desta República e, em seguida, como os outros países foram abordando a questão.

O Código Penal da República da Argentina traz expressamente este princípio em seu artigo $41^{314}$. Este artigo complementa a regra contida no artigo antecedente, segundo o qual, em caso de condenação, as penas do agente serão dosadas de acordo com a presença de circunstâncias atenuantes ou agravantes particulares em cada caso concreto e estas serão identificadas pela observância dos requisitos contidos no artigo 41 abaixo traduzido:

\footnotetext{
${ }^{312}$ FRAGOSO, Heleno Cláudio. O direito penal comparado na américa latina. Revista de Direito Penal, $\mathrm{n}$. 24, Rio de Janeiro, 1979, p. 17-25.

${ }^{313}$ WACQUANT, Loïc. As Prisões da Miséria. Rio de Janeiro: Jorge Zahar, 2001, p. 7.

314 Artículo 41 Código Penal de la República Argentina. A los efectos del artículo anterior, se tendrá en cuenta: $1^{\circ}$. La naturaleza de la acción y de los medios empleados para ejecutarla y la extensión del daño y del peligro causados; $2^{\circ}$. La edad, la educación, las costumbres y la conducta precedente del sujeto, la calidad de los motivos que lo determinaron a delinquir, especialmente la miseria o la dificultad de ganarse el sustento propio necesario y el de los suyos, la participación que haya tomado en el hecho, las reincidencias en que hubiera incurrido y los demás antecedentes y condiciones personales, así como los vínculos personales, la calidad de las personas y las circunstancias de tiempo, lugar, modo y ocasión que demuestren su mayor o menor peligrosidad. El juez deberá tomar conocimiento directo y de visu del sujeto, de la víctima y de las circunstancias del hecho en la medida requerida para cada caso.
} 
Para fins do artigo anterior, serão levados em conta: 1. A natureza da ação e os meios para executá-la e a extensão dos danos e perigo causado; 2. Idade, educação, costumes e comportamento do indivíduo, a qualidade das razões que o levaram a cometer crimes, especialmente a miséria ou a dificuldade de ganhar a vida para seu próprio sustento e o dos seus, a participação que teve no fato, a reincidência e outras circunstâncias antecedentes e pessoais, assim como os vínculos pessoais, a qualidade das pessoas e as circunstâncias de tempo, lugar, modo e ocasião que demonstrem sua maior ou menor periculosidade. O juiz deve tomar conhecimento direto do indivíduo, da vítima e das circunstâncias do ato, na medida necessária para cada caso (tradução livre).

Disso se depreende que, na Argentina, a questão da influência do meio no comportamento do agente ou, nos termos do item dois do artigo 41, a idade, a educação recebida, os costumes do sujeito, a qualidade dos motivos que o levaram ao crime, em especial a pobreza e a dificuldade de ganhar a vida por si só sem contar com o apoio de nenhuma outra pessoa ou entidade, funciona como circunstância que tanto pode atenuar a pena do agente como também para aumentá-la ${ }^{315}$.

Essa disposição abrangente do artigo 40 do Código Penal da República da Argentina equivale à regra do artigo 68 do Código Penal brasileiro, no que atine às fases de fixação da pena, segundo José Antonio Paganella Boschi ${ }^{316}$.

Ao comentar referidas disposições, Eugenio Raul Zaffaroni enaltece que, embora não tendo sido nestes moldes as primeiras noções que os doutrinadores argentinos atribuíram ao instituto, revelou-se um avanço legislativo para o Direito Penal do país, hoje, ver o princípio da coculpabilidade expresso no ordenamento ${ }^{317}$.

O doutrinador argentino explica que a positivação de referido princípio obrigou o julgador a ficar mais atento para as peculiaridades da vida do ser humano que está diante dele e que irá receber a pena, por isso, o artigo frisa a questão da pobreza e da dificuldade de se ganhar a vida como fatores em relação aos quais o juiz não poderá passar despercebido no ato de fixar a reprimenda para a conduta delituosa ${ }^{318}$.

Da análise dos artigos acima referidos e das considerações de Eugenio Raul Zaffaroni acerca do modo como o Código Penal argentino recepciona o princípio da

\footnotetext{
315 Artículo 40 Código Penal de la República Argentina. En las penas divisibles por razón de tiempo o de cantidad, los tribunales fijarán la condenación de acuerdo con las circunstancias atenuantes o agravantes particulares a cada caso y de conformidad a las reglas del artículo siguiente.

${ }^{316}$ BOSCHI. José Antonio Paganella. Op.cit., p. 173-181.

${ }^{317}$ ZAFFARONI, Eugenio Raul. Politica criminal latino-americana, p. 167.

${ }^{318}$ Idem.
} 
coculpabilidade, há de se considerar que faz sentido o paralelo que José Antonio Paganella Boschi $^{319}$ traça em relação ao artigo 68 do Código Penal brasileiro ${ }^{320}$.

A redação do artigo 40 deixa claro que a análise da coculpabilidade se opera de forma genérica, ou seja, na fase de fixação da pena em que não se permite que esta ocorra abaixo do mínimo legal e, por isso, os efeitos práticos da adoção de tal princípio restam quase que imperceptíveis se o agente teve a pena base arbitrada no patamar mínimo.

A ideia de coculpabilidade também vem prevista expressamente no Código Penal da República do Peru, em seu artigo $45^{321}$, que se traduz:

Pressupostos para fundamentar e determinar a pena. 1.As carências sociais que sofreu o agente; 2.Sua cultura e seus costumes, e 3. Os interesses da vítima, sua família ou as pessoas que dele dependem (tradução livre).

Este dispositivo estabelece que, ao estipular a pena do réu, o juiz deverá considerar as carências sociais sofridas pelo sujeito que será apenado durante sua vida, bem como sua cultura e os costumes do lugar em que cresceu e se desenvolveu.

As palavras contidas no artigo do Código Penal peruano acima mencionado traduzem a expressa adoção do princípio da coculpabilidade por essa legislação; isso significa que se aceita uma responsabilidade por parte da sociedade e do Estado no que tange às condutas criminosas praticadas por aqueles que se encaixam nas condições de vivência social mencionadas no referido artigo 45 e, por essa "meia culpa", se limita o poder de punir do Estado, atenuando-se a pena a ser aplicada ao delinquente.

O princípio da coculpabilidade também se apresenta expresso na legislação colombiana, mais especificamente no artigo 56 do Código Penal da Colômbia, Lei n. 599 de 24 de Julho de $2000^{322}$.

$\mathrm{Na}$ lei colombiana, o reconhecimento deste princípio é requisito que afeta a punibilidade, podendo reduzi-la ou, até mesmo, excluí-la.

\footnotetext{
${ }^{319}$ BOSCHI. José Antonio Paganella. Op.cit., p. 173-181.

${ }^{320}$ Artigo 68 do Código Penal Brasileiro. A pena-base será fixada atendendo-se ao critério do art. 59 deste Código; em seguida serão consideradas as circunstâncias atenuantes e agravantes; por último, as causas de diminuição e de aumento.

${ }^{321}$ Artículo 45 Código Penal de la Republica del Peru. Presupuestos para fundamentar y determinar la pena. 1. Las carências sociales que hubiere sufrido el agente; 2 . Su cultura y sus costumbres; y 3.Los intereses de la victima, de su família o de las personas que de ella dependen.

${ }^{322}$ Artículo 56 Código Penal de la Republica de Colombia. El que realice la conducta punible bajo la influencia de profundas situaciones de marginalidad, ignorancia o pobreza extremas, en cuanto hayan influido directamente en la ejecución de la conducta punible y no tengan la entidad suficiente para excluir la responsabilidad, incurrirá en pena no mayor de la mitad del máximo, ni menor de la sexta parte del mínimo de la señalada en la respectiva disposición.
} 
Traduzindo-se o artigo 56 do Código Penal da República da Colômbia, tem-se que incorrerá em pena não maior do que a metade do máximo nem menor que a sexta parte do mínimo aquele que realizar a conduta punível sob a influência de profundas situações de marginalidade, ignorância ou pobreza extremas, na medida em que não tenham aquelas força suficiente para excluir a responsabilidade.

No Equador, por sua vez, a culpabilidade por vulnerabilidade se limita aos crimes patrimoniais, consoante dispõe o artigo 29, item 11 do Código Penal equatoriano ${ }^{323}$.

Diz referido artigo que vai ser atenuada a pena do agente quando, no caso, se vislumbrar circunstâncias que denotem reduzida repercussão social ou baixa gravidade e se relacionem com a capacidade física ou intelectual dele e à sua conduta criminosa ou às consequências desta.

Art. 29 - São circunstâncias atenuantes: todas as que, referindo-se às causas impulsivas da infração, ao estado e a capacidade física e intelectual do delinquente, a sua conduta com respeito ao ato e às consequências, diminuem a gravidade da infração, ou a repercussão causada na sociedade, e dão a conhecer a pouca ou nenhuma periculosidade do autor como nos casos seguintes: [...] 11 - Nos delitos contra a propriedade, quando a indigência, a numerosa família, ou a falta de trabalho tenha colocado o delinquente em uma situação excepcional; ou quando uma calamidade pública fez com que se tornasse muito difícil conseguir honradamente os meios de subsistência, na época em que cometeu a infração (tradução livre).

Na Costa Rica, a coculpabilidade não tem previsão expressa no Código Penal, Lei n. 4.573 de 4 de março de 1970, mas sua aplicabilidade se assemelha a que já foi sugerida em âmbito do Direito Penal brasileiro por força do disposto no artigo 66 do Código Penal pátrio.

O artigo 71 do Código Penal da Costa Rica ${ }^{324}$ dispõe que, em sentença motivada, o juiz determina a duração da pena que será imposta, de acordo com os limites estabelecidos

\footnotetext{
${ }^{323}$ Artículo 29 Codigo Penal de la Republica del Ecuador. Son circunstancias atenuantes todas las que: refiréndose a las causas impulsivas de la infracción, al estado y capacidade física y intelectual del delincuente, a su conducta con respecto de lacto y sus consecuencias, disminuyen la gravedad de la infracción, o la alarma ocasionada en la sociedade, y dan a conocer la poca o ninguna peligrosidad del autor, como en los casos siguientes: 11. En los delictos contra la propriedad, cuando la indigencia, la numerosa família, o la falta de trabajo han colocado al delincuente en una situación excepcional; o cuando una calamidade pública le hizo muy difícil conseguir honradamente los medios de subsistencia, en la época en que cometió la infracción.

${ }^{324}$ Artículo 71 Código Penal de Costa Rica. El Juez, en sentencia motivada, fijará la duración de la pena que debe imponerse de acuerdo con los límites señalados para cada delito, atendiendo a la gravedad del hecho y a la personalidad del partícipe. Para apreciarlos se tomará en cuenta: a) Los aspectos subjetivos y objetivos del hecho punible; b) La importancia de la lesión o del peligro; c) Las circunstancias de modo, tiempo y lugar; d)
} 
em cada infração penal e tendo em vista a gravidade do fato e a personalidade do participante. Para tal apreciação se consideram: a) os aspectos subjetivos e objetivos da infração; b) a importância da lesão ou do perigo; c) as circunstâncias de tempo, modo de execução e lugar do crime; d) a qualidade dos motivos determinantes; e) outras características pessoais do agressor ou da vítima que tenham influenciado na prática da infração; e f) a conduta do agente após o cometimento do crime. As características psicológicas, psiquiátricas e sociais, bem como as relativas à educação e à história de vida do indivíduo poderão ser requeridas ao Instituto de Criminalística, que poderá incluir no relatório qualquer outro aspecto relevante e necessário a informar o juiz.

O Código Penal da Costa Rica acaba por ser mais específico do que o brasileiro no que atine a essa questão da redução da pena por incidência de tal atenuante; assim como o do Peru, faz menção às condições de vida do apenado e determina a inclusão de sua vida pregressa, a fim de constatar se houveram situações que influenciaram na prática do delito.

No Direito Penal do México o princípio da coculpabilidade tem previsão expressa, conforme denota o artigo 52 do Código Penal deste país ${ }^{325}$, assim traduzido:

Art. 52. O juiz fixará as penas e medidas de segurança que estime justas e procedentes dentro dos limites assinalados para cada delito, com base na gravidade do ilícito e no grau de culpabilidade do agente, tendo em vista: [...] V. A idade, a educação, o esclarecimento, os costumes, as condições sociais e econômicas do sujeito, assim como os motivos que o impulsionaram ou determinaram a delinqüir. Quando o processado pertencer a algum povo ou comunidade indígena, se levarão em conta, além de tudo, seus usos e costumes; [...] VII. As demais condições especiais e pessoais em que se encontrava o agente no momento do cometimento do delito, sempre e quando sejam relevantes para determinar a possibilidade de haver ajustado sua conduta às exigências da norma (tradução livre).

Vislumbra-se que aqui a coculpabilidade é prevista com redação similar à utilizada pelo Código Penal argentino, porém, corresponde, no Direito Penal Mexicano a uma

\footnotetext{
La calidad de los motivos determinantes; e) Las demás condiciones personales del sujeto activo o de la víctima en la medida en que hayan influido en la comisión del delito; y f) La conducta del agente posterior al delito. Las características psicológicas, psiquiátricas y sociales, lo mismo que las referentes a educación y antecedentes, serán solicitadas al Instituto de Criminologia el cual podrá incluir en su informe cualquier outro aspecto que pueda ser de interes para mejor información del Juez.

${ }^{325}$ Artículo 52 Codigo Penal del Estado de México. El juez fijará las penas e de medidas de seguridad que estime justas y procedentes dentro de los limites señalados para cada delito, con base en la gravedad del ilícito y el grado de culpabilidad del agente, teniendo en cuenta: V - la edad, la educación, la ilustración, las costumbres, las condiciones sociales e econômicas del sujeto, así como los motivos que lo impulsaron o determinaron a delinquir. Cuando el procesado perteneciere a un grupo étnico indígena, se tomarán en cuenta, además, sus usos y costumbres.
} 
circunstância judicial, que incide na primeira fase de aplicação da pena, com o diferencial de ser estendida expressamente à aplicação das medidas de segurança.

O Paraguai também prevê a coculpabilidade expressamente em seu ordenamento jurídico, mais precisamente no artigo 65 do Código Penal, como circunstância a ser considerada quando o juiz for determinar a pena ${ }^{326}$.

Referido artigo contém a base da mensuração da pena, que é pautada pela culpabilidade do autor do fato e possui finalidade preventiva. Assevera o dispositivo que para o juiz fixar a pena, deve analisar todas as circunstâncias, tanto a favor quanto contra a pessoa do delinquente e, em especial, os motivos do autor, seu comportamento perante a exigência da lei, a reprovabilidade do crime cometido, o grau de inobservância ao dever jurídico de cuidado nos crimes omissivos, a extensão do dano e as consequências trazidas pelo crime, a vida pregressa do autor do fato e suas condições pessoais e econômicas, seu comportamento depois de ter cometido o crime, seu esforço para reparar o dano e obter o perdão da vítima.

Observa-se que, no Paraguai, a questão de se considerar a vida pregressa do infrator, bem como suas condições econômicas e pessoais, é analisada com as circunstâncias judiciais e tanto pode atenuar quanto agravar a pena.

Em Portugal também se vislumbra que as condições econômicas do agente servem de critério para mensuração da pena. É o que traz a alínea $d$ do artigo 77 do Código Penal português $^{327}$.

\footnotetext{
${ }^{326}$ Artículo 65 Código Penal de Paraguay. Ley n. 1.169/1997. Bases de la medición: $1^{\circ}$ La medición de la pena se basará en la reprochabilidad del autor y será limitada por ella; se atenderán también los efectos de la pena en su vida futura en sociedad. $2^{\circ} \mathrm{Al}$ determinar la pena, el tribunal sopesará todas las circunstancias generales en favor y en contra del autor y particularmente: 1. los móviles y los fines del autor; 2 . la actitud frente al derecho; 3. la intensidad de la energía criminal utilizada en la realización del hecho; 4. el grado de ilícito de la violación del deber de no actuar o, en caso de omisión, de actuar; 5. la forma de la realización, los medios empleados, la importancia del daño y del peligro, y las consecuencias reprochables del hecho; 6 . la vida anterior del autor y sus condiciones personales y económicas; y 7. la conducta posterior a la realización del hecho y, en especial, los esfuerzos para reparar los daños y reconciliarse con la víctima. $3^{\circ} \mathrm{En}$ la medición de la pena, ya no serán consideradas las circunstancias que pertenecen al tipo legal.

${ }^{327}$ Artigo 77 do Código Penal Português. Determinação da medida da pena: d) as condições pessoais do agente e sua situação econômica.
} 


\section{A COCULPABILIDADE NO ORDENAMENTO JURÍDICO BRASILEIRO}

\section{1 - Onde já aparece}

No Brasil, não se tem o princípio da coculpabilidade expresso; contudo, analisando a legislação penal, é possível identificar entendimentos já no sentido de concebê-lo, não com o nome explícito, mas em sua essência.

Tal qual a legislação argentina que permite que a análise das condições socioeconômicas nas quais a pessoa nasceu e se desenvolveu incida na dosagem da pena, servindo para mensurar o juízo de reprovação, maior ou menor, da conduta, na legislação penal brasileira igualmente se encontram dispositivos que realizam juízo de valor similar.

O artigo 76 do Código de Defesa do Consumidor, Lei n. 8078/1990, ao elencar as circunstâncias agravantes dos crimes tipificados naquele documento, estipula, na alínea $a$ do inciso IV que será agravada a pena quando o crime for cometido por pessoa cuja condição socioeconômica seja manifestamente superior à da vítima ${ }^{328}$.

Além desse, o parágrafo segundo do artigo $4^{\circ}$ da Lei n. 1521/1951, que trata dos crimes contra a economia popular, determina que seja uma circunstância agravante do crime de usura quando este for cometido por pessoa cuja condição socioeconômica seja manifestamente superior à da vítima ${ }^{329}$.

As duas hipóteses mencionadas acima são praticamente idênticas. O Código de Defesa do Consumidor apenas adaptou o artigo já existente na lei de 1.951, mas sua aplicabilidade no âmbito das relações sociais tuteladas pelo Direito Penal somente será confirmada ou não pelo juízo de valor dos juízes ante o julgamento dos casos conforme estes forem surgindo nos tribunais ${ }^{330}$.

O artigo 187 do Código de Processo Penal dispõe que “o interrogatório será constituído de duas partes: sobre a pessoa do acusado e sobre os fatos”. Em seu parágrafo primeiro é que se denota a preocupação do legislador com as condições em que a pessoa do delinquente se desenvolveu como ser humano, quando referido dispositivo especifica: "na

\footnotetext{
${ }^{328}$ Artigo76 do Código de Defesa do Consumidor. São circunstâncias agravantes dos crimes tipificados neste código: IV. quando cometidos: a) por servidor público, ou por pessoa cuja condição econômico-social seja manifestamente superior à da vítima.

${ }^{329}$ Art. $4^{\circ} \$ 2^{\circ}$ da Lei n. 1521/51. São circunstâncias agravantes do crime de usura: IV. Quando cometido: a) por militar, funcionário público, ministro de culto religioso; por pessoa cuja condição econômico-social seja manifestamente superior à da vítima.

${ }^{330}$ FONSECA, Antonio Cezar Lima da. Direito Penal do Consumidor. Porto Alegre: Livraria do Advogado, 1996, p. 114 e 115.
} 
primeira parte o interrogando será perguntado sobre a residência, meios de vida ou profissão, oportunidades sociais, lugar onde exerce a sua atividade, vida pregressa, notadamente se foi preso ou processado alguma vez e, em caso afirmativo, qual o juízo do processo se houve suspensão condicional ou condenação, qual pena imposta, se a cumpriu e outros dados familiares e sociais" ${ }^{\prime 331}$.

Tem-se então que a partir dos fundamentos da teoria da coculpabilidade e da noção que seu conceito abarca, considerando-se ainda o princípio de hermenêutica que diz que a lei não contém palavras vãs, a inserção no texto legal dos termos "oportunidades sociais" e "outros dados familiares e sociais" como fatores tendentes a informar ao juízo dados relevantes acerca da vida do réu se dá para que o julgador considere tais elementos no momento da aplicação da pena ao acusado.

Como o artigo 59 do Código Penal, que fornece ao juiz as diretrizes para a fixação da pena base, expressa a observância de requisitos como a culpabilidade, da personalidade, dos antecedentes, da conduta social do agente, então, é possível entender que o transcrito artigo do Código de Processo Penal tem por escopo delimitar o momento processual para que se colham as informações sobre tais aspectos da vida do acusado, já que isso importa tanto a ponto de influenciar na quantidade da pena base que será atribuída ao indivíduo.

Antes de o artigo 187 do Código de Processo Penal sofrer a alteração em seu conteúdo pela Lei n. 10.792/2003 e passar a figurar como transcrito acima, já existia no ordenamento brasileiro o artigo 14 da Lei n. 9.605/1998 332 já expunha, em seu inciso I que o baixo grau de instrução ou escolaridade do agente corresponde a uma circunstância que atenua a pena.

Dizer que a baixa escolaridade ou instrução do autor de infrações ou crimes ambientais se revela circunstância capaz de atenuar a pena é assumir que se considera que a reprovabilidade da conduta daquela pessoa é menor do que a de outra, em face de ela não ter tido as oportunidades normais e ideais de desenvolvimento que a possibilitassem se comportar de acordo com a norma.

Embora se vislumbre a noção conceitual da coculpabilidade nos artigos de lei apontados, esta não aparece de forma expressa, motivo pelo qual se objetivou desenvolver o presente estudo no sentido de se compreender a importância do tema e a necessidade de seu reconhecimento e de sua aplicabilidade prática no mundo jurídico.

\footnotetext{
${ }^{331}$ Redação do artigo 187 do Código de Processo Penal alterada pela Lei n. 10.792 de 1 de dezembro de 2003.

${ }^{332}$ Lei n. 9.605, de 12 de fevereiro de 1998, dispõe sobre as sanções penais e administrativas derivadas de condutas e atividades lesivas a o meio ambiente e dá outras providências.
} 


\section{2 - Hipóteses possíveis de positivação}

No capítulo anterior, ao se apresentar o princípio da coculpabilidade, foi exposto seu conceito, suas implicações, suas raízes constitucionais.

Entretanto, quando se cogita o reconhecimento e a aplicação do mesmo nos casos práticos, o que parece ser tão claro e coerente se torna controverso. Observa-se nítido receio por parte dos julgadores em conferir validade a um conceito que não se encontra expresso no ordenamento jurídico.

Daí se depreende a necessidade premente de positivar o princípio. Ora, quando um determinado conceito é codificado, tanto se analisando pelo ponto de vista do conteúdo, quanto pelo ponto de vista estilístico, transforma-se na expressão de uma cultura social evoluída, isto porque a codificação, desde os seus primórdios, representa um plano global da construção do Estado a partir dos fundamentos de base da sociedade humana ${ }^{333}$.

O representante do Estado é o homem do povo, para quem o direito se mostra somente como lei, como comando autoritário que cai do alto e incide sobre a indefesa comunidade dos cidadãos, muitas vezes sem considerar aquilo que circunda efetivamente na consciência coletiva, mostrando-se indiferente à diversidade das situações que deve regular. Desta feita, o Estado moderno assegura aos cidadãos somente um complexo de garantias formais e o ideal da justiça permanece como objetivo exterior do ordenamento jurídico ${ }^{334}$.

É inegável que muitas leis produzidas atualmente pelo Estado encontram-se descompassadas com a realidade, necessitando de interpretações para que alcance este estágio. E é esse gritante distanciamento que Paolo Grossi ressalta ao abordar questões como a percepção do homem do povo, as garantias apenas formais e a justiça como objetivo exterior do direito contemporâneo.

A racionalização do pensamento possibilita a percepção da organização social de uma forma diferente e $^{335}$ e forma escolhida para unificar e sistematizar o direito, principalmente nos países que receberam a influência romana, foi o código.

O fenômeno da codificação gerou mudanças sensíveis na sociedade, pois foi fruto da nacionalização, ou seja, da ideia de que cada estado deveria ter seu direito e que este deveria ser baseado no espírito daquele povo; a codificação reforçou o triunfo dos códigos

\footnotetext{
${ }^{333}$ WIEACKER, Franz. História do Direito Privado Moderno. Lisboa: Fundação Calouste Gulbenkian, 2004, p.378.

${ }^{334}$ GROSSI, Paolo. Mitologias jurídicas da modernidade. Florianópolis: Fundação Boiteux, 2004, p. 23 e 24.

${ }^{335}$ HESPANHA, António Manuel. Cultura jurídica européia: síntese de um milênio. Florianópolis: Fundação Boiteux, 2005, p. 329.
} 
nacionais sobre o direito nacional e o cosmopolita direito romano que deram lugar a diferentes ordens jurídicas nacionais baseadas em códigos nacionais e na administração nacional da justiça. Esse desenvolvimento acompanhou o dos Estados soberanos nesse mesmo período, assim como o de várias correntes intelectuais. Preconizou-se a ideia de que cada povo deveria viver com suas próprias leis, adaptadas às suas necessidades específicas $^{336}$.

Essas considerações acerca da importância da codificação importam ao tema em estudo no sentido de que o princípio da coculpabilidade ainda não se encontra expresso no ordenamento jurídico brasileiro, suscitando controvérsias em sua aplicabilidade nas situações em que vem a ser reconhecido.

Observa-se que muitos magistrados se negam até mesmo reconhece-lo por não estar expresso na legislação, o que provocou a reflexão acerca da necessidade de se positivar o princípio.

Tem-se que os princípios são espécies de normas jurídicas que, assim como as regras, são formulados por expressões deônticas fundamentais como mandamento, permissão e proibição e se constituem em fundamentos para juízos concretos de dever $\operatorname{ser}^{337}$.

Os princípios ordenam a realização de um direito na maior de suas esferas, no âmbito das reais possibilidades jurídicas e fáticas existentes ${ }^{338}$.

Isso significa que os princípios jurídicos podem ser concretizados em diferentes graus que se diversificam de acordo com as condições fáticas e jurídicas, ou seja, um determinado princípio pode ter diferentes formas de aplicação quando subsumido a uma situação específica da vida cotidiana e o valor conferido a ele em um dado episódio poderá ser diferente quando se necessitar aplica-lo em outro caso.

Neste diapasão, de acordo com a mencionada lição de Robert Alexy, as regras jurídicas, que são normas que prescrevem uma situação ou impõem um determinado comportamento, devem ser cumpridas na exata medida de suas prescrições, não deixando margem à graduação de aplicação, quando forem reconhecidamente válidas.

As regras de hermenêutica revelam-se, por vezes, inconsistentes para conferir ao Direito um estatuto racional. Quando, ao apreciar um determinado fato, o juiz encontrar dificuldade na solução por causa da vagueza dos enunciados normativos e da insuficiência

${ }^{336}$ CAENEGEM, R. C. van. Uma introdução histórica ao direito privado. São Paulo: Martins Fontes, 1999, p.201.

${ }^{337}$ ALEXY, Robert. Op.cit., p. 83.

${ }^{338}$ Idem, p. 86. 
dos critérios de interpretação, proferirá a decisão com base em seu próprio juízo de valor $^{339}$.

Robert Alexy sustenta ainda que o discurso jurídico se dá em condições limitativas (a vinculação à lei, à doutrina, à jurisprudência) e cria um enunciado normativo pretensamente correto e que se revela complexo e apto à constituição de um discurso racional capaz de fundamentar a decisão. Cogita o autor então a possibilidade de se fundamentar uma decisão jurídica segundo uma teoria da argumentação que observa um sistema de regras discursivas e formas de argumentos que viabilizam o julgamento de modo racional ${ }^{340}$.

Demonstrado que a positivação do princípio da coculpabilidade conferiria aos julgadores a sensação de segurança de proferir uma decisão em consonância com a lei pátria, cumpre analisar como seria possível se dar esta inserção expressa de referido princípio no Código Penal brasileiro.

Grégore Moura $^{341}$ considera quatro opções de positivação da coculpabilidade, quais sejam: como circunstância judicial prevista no Artigo 59 do Código Penal; como atenuante genérica prevista no artigo 66 do Código Penal; como causa de diminuição de pena inserida na forma de parágrafo específico do Artigo 29 do Código Penal; ou como causa de exclusão da culpabilidade, tendo previsão no Artigo 29 do Código Penal.

\subsection{1 - A coculpabilidade como circunstância judicial do artigo 59 do Código}

\section{Penal.}

Como dito acima, ante a importância do tema, houve a nítida pretensão de se inserir a coculpabilidade propriamente dita no texto do Código Penal brasileiro.

As circunstâncias judiciais apresentadas no artigo 59 do Código Penal, que compreendem tanto elementos concernentes às pessoas do delinquente e da vítima quanto elementos atinentes ao delito fático em si, são valoradas exclusivamente de acordo com o arbítrio do juiz ${ }^{342}$; entretanto, como nesta primeira fase da dosimetria a pena não pode ultrapassar os limites mínimo e máximo, se todas as circunstâncias forem, por exemplo,

\footnotetext{
${ }^{339}$ ALEXY, Robert. Teoria de la argumentación jurídica. La teoria del discurso racional como teoria de la fundamentación jurídica. Traducción de Manuel Atienza e Isabel Espejo. Madrid: Centro de Estudios Constitucionales, 1989, p. 30.

${ }^{340}$ Idem, p. 34-35.

${ }^{341}$ MOURA, Grégore Moreira de. Op.cit., p. 101.

${ }^{342}$ SANTOS, Juarez Cirino dos. Teoria da Pena: fundamentos políticos e aplicação judicial. Curitiba: Lumen Juris, 2005, p. 108).
} 
favoráveis ao agente, este não será beneficiado, uma vez que deve o juiz partir do mínimo legal.

Luiz Regis Prado explica que, de acordo com o sistema da relativa determinação, a individualização legislativa da pena é complementada pela individualização judicial, de forma que o que está previamente estipulado pela lei são as espécies e o quantum das penas, mas cabe ao juiz fixa-las discricionariamente ${ }^{343}$.

O Projeto de Lei n. 3473/2000, de 27 de setembro de 2001, que altera a Parte Geral do Decreto-lei no 2.848, de 7 de dezembro de 1940 - Código Penal, elaborado pela comissão de juristas sob a presidência de Miguel Reale Júnior, prevê a inclusão do termo "as oportunidades sociais a ele (acusado) oferecidas" no "caput" do artigo $59^{344}$, bem como o artigo $68 \mathrm{~A}$, segundo o qual "nos crimes cometidos sem violência ou grave ameaça à pessoa, o juiz, observado o critério do art. 59, e havendo desproporcionalidade entre a pena mínima cominada e o fato concreto, poderá, fundamentadamente, reduzir a pena de um sexto até metade" 345 .

Quem defende que a coculpabilidade deve ser analisada como uma circunstância judicial segue o seguinte raciocínio: quando, em razão de condicionantes sociais, uma pessoa pode não ser dotada de capacidade suficiente para se autodeterminar, de modo que a valoração dos motivos que ensejaram a prática ilícita por ela cometida deve levar em consideração tais restrições.

Este é o caso do autor Paulo Queiroz que, inclusive, entende que, de acordo com um Direito Penal Garantista, seria plenamente possível fixar a pena base abaixo do mínimo legal já na primeira fase da dosimetria.

Esta hipótese, no entanto, revela-se tímida, uma vez que se torna impraticável reconhecer aqui a coculpabilidade, pois a pena base deve partir do mínimo legal, não podendo, por força da súmula 231 do Superior Tribunal de Justiça, ser fixada aquém deste parâmetro $^{346}$.

\footnotetext{
${ }^{343}$ PRADO, Luiz Regis. Curso de Direito Penal brasileiro: parte geral. 3.ed. São Paulo: Editora Revista dos Tribunais, 2002, p.535.

${ }^{344}$ Art. 59 - O juiz, atendendo à culpabilidade, aos antecedentes, à conduta social, à personalidade do agente, aos motivos, às circunstâncias e consequências do crime, bem como ao comportamento da vítima, estabelecerá, conforme seja necessário e suficiente para reprovação e prevenção do crime: I - as penas aplicáveis dentre as cominadas; II - a quantidade de pena aplicável, dentro dos limites previstos; III - o regime inicial de cumprimento da pena privativa de liberdade; IV - a substituição da pena privativa da liberdade aplicada, por outra espécie de pena, se cabível.

${ }^{345}$ Projeto de Lei n. 3473/2000, de 27 de setembro de 2001. Altera a Parte Geral do Decreto-lei no 2.848, de 7 de dezembro de 1940 - Código Penal - e dá outras providências.

${ }^{346}$ MOURA, Grégore Moreira de. Op.cit., p. 94.
} 
Frise-se que o disposto em referida súmula é seguido pela maioria, senão unanimidade, dos julgadores, consoante se depreenderá dos acórdãos apresentados no item 3.3 do presente trabalho.

\subsection{2 - A coculpabilidade como circunstância atenuante genérica}

Entretanto, o que se vê mais comumente na moderna doutrina que, ainda de forma tímida, aborda o tema da coculpabilidade, é a defesa de que este princípio funcionaria como atenuante prevista no artigo 66 do Código Penal, o que ensejaria sua aplicação na segunda fase da fixação da pena.

Eugenio Raul Zaffaroni e José Henrique Pierangeli ${ }^{347}$ asseveram que a coculpabilidade hoje, faz parte da ordem jurídica de qualquer Estado social de direito que reconheça direitos econômicos e sociais à sua população; assim sendo, tem cabimento no Código Penal brasileiro mediante a disposição genérica do artigo 66.

Suscintamente tem-se que a pena base será fixada atendendo-se ao critério do artigo 59 do Código Penal; em seguida serão consideradas as circunstâncias atenuantes e agravantes; por último, as causas de diminuição e de aumento ${ }^{348}$.

Cabe mencionar um dizer de José Frederico Marques no sentido de que é pela sentença que se consubstancia a individualização concreta do comando emergente da norma legal. Por isso, faz-se necessário que esse trabalho de aplicação da lei se efetue com sabedoria e justiça, o que só se consegue armando o juiz de poderes discricionários na graduação e escolha das sanções penais ${ }^{349}$.

Referido autor esclarece que se trata de um arbitrium regulatum, que consiste em se possibilitar que o juiz estabeleça a quantidade concreta da pena a ser imposta, entre o mínimo e o máximo legal para individualizar as sanções cabíveis, sob critérios que o norteiam $^{350}$.

Na primeira etapa da dosimetria da pena ocorre a análise das circunstâncias judiciais contidas no artigo 59 do Código Penal; nesta fase inicial, o juiz adequa o juízo de desvalor da conduta entre os patamares mínimo e máximo que vêm previstos pelos tipos incriminadores.

\footnotetext{
${ }^{347}$ ZAFFARONI, Eugenio Raúl; PIERANGELLI, José Henrique. Op.cit., p. 613.

${ }^{348}$ Artigo 68 do Código Penal Brasileiro. A pena-base será fixada atendendo-se ao critério do art. 59 desse Código; em seguida serão consideradas as circunstâncias atenuantes e agravantes; por último, as causas de diminuição e de aumento.

${ }_{349}$ MARQUES, José Frederico. Tratado de direito penal, v. III. Campinas: Editora Millennium, 2002, p. 194.

${ }^{350}$ Idem.
} 
Na segunda fase da aplicação da pena, após a fixação da pena base, será avaliada pelo julgador a presença de circunstâncias atenuantes e agravantes no caso concreto; tais circunstâncias encontram-se previstas nos artigos 65 e 66 (atenuantes) e nos artigos 61 e 62 (agravantes) da Parte Geral do Código Penal.

Por fim, na terceira etapa da aplicação da pena, observa-se a existência de causas de aumento e de diminuição, estas se encontram previstas na Parte Especial do Código Penal e o quantum de aumento ou de diminuição vem fracionado pelo próprio texto da lei.

Contudo, as circunstâncias não interferem na definição jurídica do fato criminoso, como ocorrem com as elementares do tipo que são indispensáveis à tipicidade da conduta, mas se configuram acessório desta. Também em sua aplicabilidade revelam-se limitadas devido ao fato de não ser possível reduzir a pena abaixo do mínimo legal na segunda fase da dosimetria e ainda ao fato de não haver previsão legal do quantum de redução ou aumento essas circunstâncias ensejam.

Isso se depreende da lição de Cezar Roberto Bitencourt no sentido de que o Código Penal pátrio não estabelece a quantidade de aumento ou de diminuição das agravantes e atenuantes legais genéricas, deixando-a à discricionariedade do juiz. Por isso, necessário se faz que a variação dessas circunstâncias não deva ir muito além do limite mínimo das majorantes e minorantes que é fixado em um sexto; pois, caso contrário, as agravantes e as atenuantes se equiparariam àquelas causas modificadoras da pena, que apresentam maior intensidade, situando-se, no caso das majorantes, pouco abaixo das qualificadoras ${ }^{351}$.

Frise-se a importância da positivação deste princípio como forma de minimizar o arbítrio judicial e de que conferir obrigatoriedade em sua análise e aplicação. Como atenuante genérica, a positivação da coculpabilidade poderia se dar pela inserção de outro inciso no artigo 65 do Código Penal.

Neste sentido está a lição de Amilton Bueno Carvalho e Salo de Carvalho ${ }^{352}$ ao considerar que a norma do artigo 66 do Código Penal, como dispõe sobre as atenuantes inominadas, possibilita a recepção do princípio da coculpabilidade ainda que não se tenha esta teoria prevista no rol das circunstâncias atenuantes genéricas do artigo 65 do Código Penal Brasileiro, isto porque o texto do artigo 66 demonstra o caráter não taxativo das causas de atenuação; assim, o Código Penal, ao permitir a diminuição da pena em razão de “circunstância relevante, anterior ou posterior ao crime, embora não prevista em lei”, já

\footnotetext{
${ }^{351}$ BITENCOURT, Cezar Roberto. Op.cit., p. 219.

${ }^{352}$ CARVALHO, Amilton Bueno de; SALO, Carvalho de. Aplicação da pena e garantismo. 4. ed. Rio de Janeiro: Lumen Juris, 2008, p. 74/75.
} 
fornece um mecanismo para a implementação deste instrumento de igualização e justiça social.

Acerca dos ditames legais do artigo 66 do Código Penal, Alberto Silva Franco elucida que não se trata de uma circunstância qualquer, mas que tenha demonstrada sua importância para o processo individualizador da pena aplicável ao agente ${ }^{353}$.

Entretanto, depara-se aqui com o mesmo problema vislumbrado quando da pretensão de inserir a coculpabilidade como circunstância judicial do artigo 59, qual seja, a dificuldade de os juízes fixarem a pena abaixo do mínimo legal nas duas primeiras fases da dosimetria da pena, haja vista a maioria dos magistrados entende como a parte dominante da doutrina penalista no sentido de isto não ser possível.

Aliás, é com este argumento que muitos juízes se deparam com a questão do reconhecimento da coculpabilidade e, embora a reconheçam em suas decisões, acabam por não aplica-la.

No Tribunal de Justiça do Estado de Goiás, por exemplo, a Segunda Turma Julgadora da Primeira Câmara Criminal analisou cuidadosamente a questão em uma apelação criminal ${ }^{354}$ cujo crime discutido era violação de direito autoral.

Vale transcrever o trecho do voto do Desembargador Relator do acórdão no qual o julgador analisou o pedido de acolhimento da coculpabilidade:

“O princípio da culpabilidade social cuida que mereça ser visto com simpatia, não pode ser dilargado ao ponto de confundir-se com a leniência culposa e a

${ }^{353}$ FRANCO, Alberto Silva. Código Penal e sua Interpretação Jurisprudencial. 5.ed. São Paulo: Revista dos Tribunais, 1995 , p. 378.

${ }^{354}$ Apelação n. 415946-21.2007.8.09.0051. Original da comarca de Goiânia. Relator Desembargador Itaney Francisco Campos. Data do acórdão - 25/10/2011. Ementa: APELAÇÃO CRIMINAL. VIOLAÇÃO DE DIREITO AUTORAL. PRELIMINAR DE. INÉPCIA DA DENÚNÇIA. REJEITADA. ABSOLVIÇÃO. INEXIGIBILIDADE DE CONDUTA DIVERSA. COCULPABILIDADE ESTATAL. PRINCÍPIOS DA INSIGNIFICÂNCIA E DA INTERVENÇÃO MÍNIMA. IMPOSSIBLIDADE. 1. Se a inicial acusatória preenche satisfatoriamente os requisitos do artigo 41 do Código de Processo Penal, com descrição de conduta típica, trazendo em seu bojo um suporte probatório que permite identificar o modo como o fato supostamente delituoso ocorreu e, ainda, possibilitando a visualização clara e objetiva da forma como o acusado teria praticado o delito, permitindo-lhe o exercício de ampla defesa, não cabe falar em inépcia da denúncia. 2. Improcede a tese de inexigibilidade de conduta diversa, uma vez evidenciado nos autos que o apelante tinha conhecimento e consciência da ilicitude que praticava, até porque os CD's e DVD's comercializados trazem a advertência de que é proibida a reprodução. O fato do réu ser pobre e estar desempregado à época não autoriza a lesão ao direito dos artistas dos CD's e DVD's que vendia, nem de terceiros que detenham os respectivos direitos autorais. 3. Admissível o reconhecimento da atenuante inominada prevista em lei (artigo 66 do Código Penal), concernente à "coculpabilidade social”, uma vez que as desigualdades existentes em nossa sociedade podem inserir-se nas circunstâncias da prática do fato como vetor favorável ao sentenciado, para mitigação da pena-base. 4. Os princípios da insignificância e da intervenção mínima devem ser afastados, em se tratando do tipo penal previsto no art. 184, do Código Penal, ressalvadas situações especialíssimas, eis que o preceito penal tutela não apenas o patrimônio do autor, como também o seu direito subjetivo à própria obra imaterial criada cuja proteção foi alçada a direito fundamental reconhecido no art. $5^{\circ}$, XXVII, da Constituição Federal, demonstrando a real relevância jurídica e o maior desvalor da ação.

RECURSO IMPROVIDO. 
atitude omissa do Estado em relação ao seu dever de fazer cumprir o ordenamento jurídico vigente no País, que vive sob a égide do Direito, a luz dos preceitos constitucionais. (...) As desigualdades marcantes que caracterizam a nossa sociedade não podem servir de justificativa plena para lesar o direito alheio, da mesma forma que não podem ser tidas como circunstância relevante para a prática delitiva, embora possam ser admitidas como atenuante genérica prevista no art. 66 do CP, em moldes a possibilitar, no âmbito da discrição vinculada do julgador, a modulação da sanção com vistas às condições pessoais do apenado e as circunstâncias de sua inserção social. Isso nada mais representa do que a aplicação do princípio da proporcionalidade, de matriz constitucional. Sobre o tema, destaque-se a lição de Guilherme de Souza Nucci (Código penal comentado. 10. ed. São Paulo: Editora Revista dos Tribunais, 2010. p. 234 e 235), in verbis: 'Conceito de coculpabilidade: trata-se de uma reprovação conjunta que deve ser exercida sobre o Estado, tanto quanto se faz com o autor de uma infração penal, quando se verifica não ter sido proporcionada a todos igualdade de oportunidades na vida, significando, pois, que alguns tendem ao crime por falta de opção. Esclarecem Zaffaroni e Pierangeli (Manual de direito penal brasileiro - parte geral, p. 613) que há sujeitos que têm um menor âmbito de autodeterminação, condicionado desta maneira por causas sociais. Não será possível atribuir estas causas ao sujeito e sobrecarregá-lo com elas no momento da reprovação de culpabilidade. Assim, deveria haver a aplicação da atenuante inominada do art. 66'. Ressalte-se, ao cabo de suas ponderações, o ilustrado penalista sustenta restrições quanto à aplicabilidade dessa circunstância atenuante. A matéria, como se percebe, enseja controvérsias e acentuada polêmica. A meu ver, o mais inadequado é a tendência a generalizar-se a incidência da regra, sem atentar-se às especificidades de cada caso concreto. Desse modo, tal circunstância atenuante não pode ser aplicada a toda prática delitiva perpetrada por cidadãos que se dediquem a atividade ilícita, como forma de justificar a infração, pois assim se estaria desvirtuando os reais propósitos para o reconhecimento das atenuantes genéricas previstas no art. 66 do Código Penal, sob pena de leniência com as ações criminosas. Em suma, é necessário sopesar as circunstâncias específicas, que só a casuística permitirá identificar. Proveitoso, ainda, trazer 
o apontamento doutrinário do jurista Luiz Flávio Gomes (Direito penal: parte geral. Vol. 2. São Paulo: Editora Revista dos Tribunais, 2007. p. 572 e 573) acerca do tema, in verbis: 'Zaffaroni e Pierangeli fazem referência à coculpabilidade para explicar que quando a sociedade é desorganizada, discriminatória, excludente, marginalizadora etc., ou seja, quando ela cria condições sociais que reduzem o âmbito de determinação e liberdade do agente (pouco espaço social, que se limita à subsistência), ela também contribui para o delito. Haveria, então, co-culpabilidade dela, isto é, o sujeito é culpável, mas a sociedade também o é. Cuida-se de tese que ganhou muita força nos países do chamado socialismo real (comunistas). Em termos práticos, isso poderia conduzir a uma redução da pena do condenado (a quem não se concedeu espaço social adequado para o seu desenvolvimento), tendo em vista o menor grau de censura (de reprovação). O juiz, caso venha a adotar essa teoria, deveria fundamentar a redução da pena no próprio art. 59 do CP ou ainda no art. 66 do CP. É mais complicada a questão consistente em saber se se pode chegar ao extremo de que a desorganização social venha a ter relevância para absolver o culpado (pelo injusto que cometeu). Situações concretas excepcionais poderiam justificar o afastamento da culpabilidade (em razão da inexigibilidade da conduta diversa). Em suma, a tese da coculpabilidade serve para diminuir a pena do réu (não para absolvê-lo, a não ser em caso absolutamente excepcional). A teoria da co-culpabilidade, entretanto, é criticada por Zaffaroni, Alagia e Slokar: (a) porque parte da premissa de que a pobreza é a causa do delito; (b) porque pode conduzir à redução das garantias quando se trata de processar e punir o rico; (c) porque ela continua ignorando a seletividade do poder punitivo'. Some-se a isso o fato de que a atenuante inominada da coculpabilidade do Estado e da sociedade (art. 66 do Código Penal) é facultativa ao juiz e somente pode ser reconhecida quando houver circunstância relevante, anterior ou posterior ao crime, já que não definida em lei. Ad argumentandum, cumpre destacar que a reprimenda do apelante foi fixada no mínimo, e diferentemente das causas de diminuição e aumento de pena, as circunstâncias atenuantes e agravantes não têm o condão de reduzir a pena aquém do mínimo legal, nem de aumentá-la acima do máximo permitido. Nesse aspecto, o egrégio Superior Tribunal de Justiça editou a Súmula $n^{o}$ 231, que preconiza: 'a incidência da circunstância 
atenuante não pode conduzir à redução da pena abaixo do mínimo legal'. Assim, havendo certeza quanto à autoria e materialidade do delito imputado ao apelante e diante da ausência de excludentes ou circunstâncias válidas para afastar o ilícito do campo de reprovabilidade, outra solução não resta senão afastar a pretensão absolutória amparada na situação social contemporânea. Ressalte-se, outrossim, que a notável e erudita peça da defesa, ao se reportar às lições de Zaffaroni, Alagia e Slokar, no sentido de que não teria pertinência que 'a sociedade não reconhecesse sua influência e parcela de responsabilidade a colocar o indivíduo em uma conjuntura social adversa, sem maiores alternativos', merece a maior atenção do julgador, e efetivamente vai repercutir no 'juízo de reprovação incidente sobre o indivíduo', especificamente no que se refere à dosagem e proporcionalidade da sanção, optando-se por medidas alternativas, menos gravosas que sanções corpóreas”.

Do voto se depreende que o Relator enfrentou o tema, buscando na doutrina as noções básicas sobre ele e que vislumbrou a possibilidade da aplicação do princípio da coculpabilidade, reconhecendo-o como circunstância relevante anterior ao crime e possível de se aplicar como atenuante genérica na segunda fase da dosimetria da pena.

$\mathrm{O}$ apelo restou improvido, entretanto, porque, em se reconhecendo a coculpabilidade como circunstância atenuante genérica, se a pena base já foi fixada no mínimo legal, como efetivamente ocorreu no caso discutido no acórdão, não se torna possível reduzir a pena aquém do mínimo legal nesta fase, devido à súmula 231 do Superior Tribunal de Justiça ${ }^{355}$.

Fica claro que esta questão sumulada foi o único óbice para o provimento do recurso no sentido de se acolher o princípio da coculpabilidade como atenuante genérica.

No ano de 2001, os desembargadores da $5^{\text {a }}$ Câmara Criminal do Tribunal de Justiça do Rio Grande do Sul consideraram em análise do recurso de a apelação de um condenado por roubo e corrupção de menores, que o "princípio da co-culpabilidade faz a sociedade também responder pelas possibilidades sonegadas ao cidadão"356.

Em verdade, neste caso, foi a juíza de Primeira Instância quem reconheceu a incidência do princípio da coculpabilidade e o aplicou ao caso como circunstância atenuante derivada da disposição legal do artigo 66 do Código Penal, o Ministério Público

\footnotetext{
${ }^{355}$ Súmula 231 do Superior Tribunal de Justiça - A incidência da circunstância atenuante não pode conduzir à redução da pena abaixo do mínimo legal.

356 TJRS - Apelação Crime n. 70002250371 - 5 Câmara Criminal; Relator Amilton Bueno de Carvalho Julgamento em 21/03/2001.
} 
recorreu da decisão que acabou mantida pelos desembargadores da $5^{\text {a }}$ Câmara que julgaram a apelação.

Do voto do Relator Amilton Bueno de Carvalho depreende-se a seguinte fundamentação acerca do reconhecimento do princípio da coculpabilidade:

"A motivação do delito, em se tratando de crime patrimonial, está vinculada ao desejo de obter lucro fácil, sem esforço e em detrimento de outrem. Entretanto, pela espécie de delito praticado (roubo de tênis, camiseta, relógio e boné), verifica-se evidente influência do sistema de desigualdades sociais vigente em nosso país, que, ao mesmo tempo em que marginaliza parcela da população, estimula o consumismo desenfreado para todos, mesmo para aqueles alijados das relações de consumo pelo pouco poder aquisitivo. Isso estimula a disputa por bens da moda e acirra o confronto de classes sociais. Note-se que esse apelo consumista atinge notadamente os adolescentes (que é o caso dos autos, pois mesmo o réu, embora penalmente imputável, tinha apenas 19 anos quando do fato, sendo ainda adolescente), portanto não se pode usar de maniqueísmo e imputar totalmente aos agentes a responsabilidade por essa conduta punível, para a qual toda a sociedade contribui (e justamente por isso —toda a sociedade é responsável, e não o indivíduo em particular- é que não é justo as vítimas sofrerem as conseqüências, merecendo, sem dúvida, proteção penal)".

(...)

"Outrossim, bem andou - vez mais - a colega singular ao aplicar o princípio da co-culpabilidade, no momento da dose da pena, porque "ao lado do homem culpado por seu fato, existe uma co-culpabilidade da sociedade, ou seja, a uma parte de culpabilidade - da reprovação pelo fato - com a qual a sociedade deve arcar em razão das possibilidades sonegadas... Se a sociedade não oferece a todos as mesmas possibilidades, que assuma a parcela de responsabilidade que lhe incumbe pelas possibilidades que negou ao infrator em comparação com as que proporcionou aos outros (Salo de Carvalho, Aplicação da Pena e Garantismo, Ed. Lumen Juris, 2001, pág. 65)”. 
No mesmo Tribunal, outro acórdão se encontra reconhecendo a coculpabilidade, mas, o interessante deste caso é que não se trata de um crime patrimonial, mas de uma tentativa de estupro ${ }^{357}$.

Um terceiro exemplo de decisão que reconhece a coculpabilidade do agente também emerge do Tribunal de Justiça do Rio Grande do Sul, em uma decisão da $6^{\text {a }}$ Câmara Criminal em relação a um crime de furto $^{358}$.

Os desembargadores mantiveram a condenação do agente, mas atenuaram a pena em razão da coculpabilidade, atrelando o fato de o indivíduo ser semialfabetizado com os ditames do artigo 66 do Código Penal; além disso, isentaram o infrator do pagamento da pena de multa sob o argumento de que sendo pobre o condenado, a pena de multa transcenderia de sua pessoa à sua família.

\subsection{3 - A coculpabilidade como causa de diminuição de pena}

Dispõe o "caput" do artigo 68 do Código Penal ${ }^{359}$ que, após a fixação da pena base e a análise das circunstâncias agravantes e atenuantes genéricas, serão consideradas as causas de aumento ou de diminuição de pena.

Como consta do artigo acima referido, estas causas serão ponderadas pelo juiz no terceiro momento da fixação da pena; calcula-se sobre o resultado da segunda operação, ou seja, da que se obtém após a incidência das agravantes e atenuantes genéricas e, dessa forma, esta será alterada para mais ou para menos, conforme a presença da causa de aumento ou de diminuição, respectivamente.

\footnotetext{
${ }^{357}$ EMBARGOS INFRINGENTES. TENTATIVA DE ESTUPRO. FIXAÇÃO DA PENA. Agente que vive de biscates, solteiro, com dificuldades para satisfazer a concupiscência, altamente vulnerável à prática de delitos ocasionais. Maior a vulnerabilidade social, menor a culpabilidade. (Zaffaroni). Prevalência do voto vencido, na fixação da pena base mínima. Regime carcerário inicial. Embargos acolhidos por maioria. (TJRS - Embargos Infringentes n. 70000792358 - $4^{\circ}$ Grupo de Câmaras Criminais; Relator: Tupinambá Pinto de Azevedo - Julgamento: 28/04/2000).

${ }^{358}$ FURTO EM RESIDÊNCIA. CONCURSO DE AGENTES. MATERIALIDADE E AUTORIA COMPROVADAS. FATO TÍPICO. INAPLICABILIDADE DO PRINCÍPIO DA INSIGNIFICÂNCIA. Além da inexistência de resultado patrimonial, a ocorrência de crime bagatelar exige análise acerca do desvalor da conduta do agente. A invasão da residência da vítima imprime desvalor à ação, tornando incabível a aplicação do princípio da insignificância. JUÍZO CONDENATÓRIO MANTIDO. INCIDÊNCIA DA ATENUANTE GENÉRICA PREVISTA NO ART. 66 DO CP. RÉU SEMI-ALFABETIZADO. INSTITUTO DA CO-CULPABILIDADE. REDUÇÃO DA PENA. MULTA. ISENÇÃO DE PAGAMENTO. POSSIBILIDADE. PENA QUE TRANSCENDE DA PESSOA DO CONDENADO POBRE, ATINGINDO SEUS FAMILIARES.

Apelação parcialmente provida. (Apelação Crime No 70013886742, Sexta Câmara Criminal, Tribunal de Justiça do RS, Relator: Marco Antônio Bandeira Scapini, Julgado em 20/04/2006).

${ }^{359}$ Artigo 68 "caput" do Código Penal brasileiro - A pena-base será fixada atendendo-se ao critério do art. 59 deste Código; em seguida serão consideradas as circunstâncias atenuantes e agravantes; por último, as causas de diminuição e de aumento.
} 
As causas gerais de aumento ou diminuição de pena vêm previamente estipuladas na parte geral do Código Penal, ao passo que as causas especiais, como a própria denominação enseja, estão previstas nos tipos penais específicos.

Hoje, as principais causas de diminuição de pena que são trazidas na parte geral do Código Penal são a figura do crime tentado ${ }^{360}$, o arrependimento posterior ${ }^{361}$, o erro inevitável sobre a ilicitude do fato ${ }^{362}$ e a participação de menor importância ${ }^{363}$. Na terceira fase da aplicação da pena, os parâmetros mínimo e máximo da pena abstrata podem ser ultrapassados.

Grégore Moura apresenta em seu estudo uma proposta mais ousada de positivação do princípio da coculpabilidade concernente à inserção de um parágrafo no artigo 29 do Código Penal, dizendo que "se o agente estiver submetido a precárias condições culturais, econômicas, sociais, num estado de hipossuficiência e miserabilidade sua pena será diminuída de um 1/3 (um terço) a 2/3 (dois terços) se a condição de miserabilidade do réu influir de forma direta na ocorrência do crime" 364 .

Pelas frações apresentadas tem-se que quanto pior as condições elencadas no supracitado parágrafo, maior seria a redução da pena.

Isto porque o artigo 29 do Código Penal dispõe que "quem, de qualquer modo, concorre para o crime incide nas penas a este cominadas, na medida de sua culpabilidade".

Na visão do autor, a inclusão de um parágrafo no artigo transcrito acima é a hipótese que mais se consonância apresenta com o Direito democrático e liberal, pois segue na esteira do garantismo penal, uma vez que permite uma individualização melhor da pena aplicada, além de poder reduzir a pena aquém do mínimo legal, dirimindo qualquer dúvida nesse aspecto, com incidência na terceira fase de sua aplicação ${ }^{365}$.

Como se tem visto em decisões que reconhecem o princípio da coculpabilidade, a questão da impossibilidade de se lograr quantidade de pena abaixo do mínimo legal nas duas primeiras fases da dosimetria deixaria de ser um óbice e, em sendo analisado como uma causa de diminuição de pena, o princípio teria maior aplicabilidade.

\footnotetext{
${ }^{360}$ Artigo 14 do Código Penal brasileiro - Diz-se o crime: II - tentado, quando, iniciada a execução, não se consuma por circunstâncias alheias à vontade do agente.

${ }^{361}$ Artigo 16 do Código Penal brasileiro - Nos crimes cometidos sem violência ou grave ameaça à pessoa, reparado o dano ou restituída a coisa, até o recebimento da denúncia ou da queixa, por ato voluntário do agente, a pena será reduzida de um a dois terços.

${ }^{362}$ Artigo 21 do Código Penal brasileiro - O desconhecimento da lei é inescusável. O erro sobre a ilicitude do fato, se inevitável, isenta de pena; se evitável, poderá diminuí-la de um sexto a um terço.

${ }^{363}$ Artigo 29 do Código Penal brasileiro - $\S 1^{\circ}$ - Se a participação for de menor importância, a pena pode ser diminuída de um sexto a um terço.

${ }^{364}$ MOURA, Grégore Moreira de. Op.cit., p. 94.

${ }^{365}$ Idem, p. 95.
} 
Desta feita a coculpabilidade seria uma causa geral de diminuição da pena, que seria prevista na parte geral do Código Penal, podendo seu reconhecimento conduzir a redução da reprimenda do infrator abaixo do mínimo legal.

\subsection{4 - A coculpabilidade como causa supralegal de exculpação}

Entretanto, existe entendimento no sentido de a coculpabilidade, como princípio constitucional, possuir um conteúdo de amplitude maior que uma simples atenuante genérica ou ainda uma eventual causa de diminuição de pena.

O Tribunal de Justiça de São Paulo julgou procedente um recurso de apelação ${ }^{366}$ do Ministério Público, vindo a condenar um réu que, em Primeira Instância, foi absolvido por incidência do Princípio da Coculpabilidade.

$\mathrm{Na}$ decisão monocrática reformada, a coculpabilidade foi considerada causa supralegal de exclusão da culpabilidade.

Destaca-se do acórdão os aspectos que interessam ao tema em estudo, dentre os quais se vislumbram o entendimento do Relator, bem como a fundamentação da juíza de Primeira Instância que conferiu aplicabilidade prática ao princípio da coculpabilidade.

As escusas de não ter outro meio para promover a própria subsistência e de sua família não pode prosperar. Fosse assim, ter-se-ia a descriminalização de outros delitos, em vista da mesma justificativa. Para quase todas as práticas criminosas, seria possível alegar que seus autores, sempre desempregados, precisam prover o seu sustento. Seria um passe livre para despenalizar, por exemplo, a prática de furtos por pessoas pobres, sob o mesmo pretexto. Por

\footnotetext{
${ }^{366}$ APELAÇÃO n. 280174320078260344. 8 a Câmara de Direito Criminal. Relator: Amado de Faria. Data: 21/06/2012. JUSTIÇA PÚBLICA VIOLAÇÃO DE DIREITOS AUTORAIS CONDENAÇÃO NECESSIDADE Réu preso em flagrante comercializando mídias visuais falsificadas Confissão administrativa e judicial Depoimento de testemunhas confirmando a apreensão Laudo técnico que atesta a falsificação Certeza quanto à materialidade e autoria DOLO ESPECÍFICO COMPROVAÇÃO Intuito de lucro patenteado Réu que admite ciência da natureza espúria dos produtos e da ilicitude atividade que exercia INEXIGIBILIDADE DE CONDUTA DIVERSA Impossibilidade de se reconhecer a prática de crimes como meio legal de subsistência Inexistência de fato capaz de superar a proibição legal TIPICIDADE Atipicidade prevista na própria Lei 9.610/1998 Inocorrência de nenhuma situação tida como apta a afastar a tipicidade Precedentes do STF COCULPABILIDADE DO ESTADO Teoria que não pode ser utilizada para afastar por completo a responsabilização do agente Preceitos que apenas interferem na dosimetria da pena Réu que, ademais, não é um indivíduo marginalizado socialmente Teoria que não poderia beneficiá-lo CONDENAÇÃO QUE SE IMPÕE PENA DOSIMETRIA Réu que ostenta mais de vinte inquéritos policiais instaurados contra si, perquirindo prática de delitos da mesma natureza Recalcitrância na prática de comércio ilegal Pena-base imposta acima do mínimo Reincidência comprovada Pena agravada Reincidência que prepondera sobre a atenuante da confissão RECURSO DE APELAÇÃO PROVIDO PARA CONDENAR O RÉU PAULO ARISTIDES DE OLIVEIRA À PENA DE 2 ANOS, 8 MESES E 20 DIAS DE RECLUSÃO, E PAGAMENTO DE 12 DIAS-MULTA, PELA PRÁTICA DO CRIME CAPITULADO NO ART. 184, § $2^{\circ}$, DO CÓDIGO PENAL.
} 
outro lado, não se pode dizer que se trate de conduta atípica. Sabe-se que no sistema jurídico penal pátrio, os costumes não têm o condão de revogar Leis. O Supremo Tribunal Federal já asseverou que o fato de a sociedade tolerar a prática do delito em questão não implicaria dizer que o comportamento se tornou lícito. Também rejeitou o pedido formulado da Tribuna de que fosse, então, aplicado na espécie o princípio da insignificância.

EMENTA: PENAL E PROCESSO PENAL. HABEAS CORPUS. CRIME DE VIOLAÇÃO DE DIREITO AUTORAL. VENDA DE CD'S “PIRATAS”. ALEGAÇÃO DE ATIPICIDADE DA CONDUTA POR FORÇA DO PRINCÍPIO DA ADEQUAÇÃO SOCIAL. IMPROCEDÊNCIA. NORMA INCRIMINADORA EM PLENA VIGÊNCIA. ORDEM DENEGADA. I A conduta do paciente amolda-se perfeitamente ao tipo penal previsto no art. 184, § 2º do Código Penal. II Não ilide a incidência da norma incriminadora a circunstância de que a sociedade alegadamente aceita e até estimula a prática do delito ao adquirir os produtos originados de contrafação. III Não se pode considerar socialmente tolerável uma conduta que causa enormes prejuízos ao Fisco pela burla do pagamento de impostos, à indústria fonográfica nacional e aos comerciantes regularmente estabelecidos. IV Ordem denegada. (Habeas Corpus $n^{o}$. 98.898, Min. Rel. Ricardo Lewandowski, J. 20.04.2010)'.

O MM. Juízo absolveu o denunciado sob fundamento de coculpabilidade do acusado. Tal teoria afirma que o Estado possui parcela de responsabilidade na prática de delitos, especialmente de natureza econômica, por indivíduos aos quais foram negados os direitos mais fundamentais, como saúde e educação; em outras palavras, indivíduos excluídos socialmente, abandonados à própria sorte. A aplicação deste preceito não exclui a culpabilidade do agente. Tão somente diz-se que o indivíduo não deve ser exclusivamente responsabilizado pelo ato por não ser o único responsável por ele. Deste modo, o princípio deve ser adotado no ato de dosagem da pena, e não para fundamentar a absolvição. Além disso, no caso em concreto, tal princípio não comporta aplicação em favor do réu. PAULO ARISTIDES foi casado e possui três filhos, e declarou ter uma vida familiar harmônica. Segundo sua qualificação, estudou o primeiro grau, possui residência fixa, até mesmo com serviço de telefonia fixa instalado. É cidadão perfeitamente inserido na sociedade e não se encaixa na 
qualificação de indivíduo marginalizado socialmente. Logo, tal teoria não pode ser utilizada para excluir sua responsabilização pelo ilícito praticado, tampouco carregar exclusivamente ao Estado a responsabilidade pela conduta ilícita perpetrada. Por estes motivos é impossível afastar do réu a culpabilidade ou se reconhecer a inexigibilidade de conduta diversa.

Por este julgado, vislumbra-se que a juíza da comarca de Marília absolveu o acusado com o entendimento de que a coculpabilidade afeta a culpabilidade do agente e, consequentemente, exclui o crime.

A $8^{a}$ Câmara do Tribunal de Justiça reconheceu que o Princípio da Coculpabilidade se coaduna com o ordenamento jurídico pátrio, porém, funcionando como circunstância atenuante e passível de incidir na segunda fase da fixação da pena, discordando da referida decisão monocrática e vindo a reforma-la para condenar o réu.

Vale frisar que, embora tendo reconhecido a vigência do princípio, a Câmara não reconheceu sua incidência no caso por considerar o indivíduo inserido na sociedade.

Entretanto, o entendimento da juíza de Primeira Instância no sentido de a coculpabilidade se configurar uma causa de exclusão da culpabilidade já encontra base doutrinária.

Ao analisar referido princípio enquanto circunstância atenuante, Juarez Cirino dos Santos reconhece que, em algumas situações, é possível que ele funcione como causa excludente de culpabilidade, uma vez que, embora as hipóteses legais de exculpação não incluírem as condições sociais adversas, quando o que deveria ser exceção torna-se regra, também os critérios devem mudar; assim sendo, se o crime configura uma resposta normal por parte de um sujeito que se encontra em uma situação social anormal, então os critérios de inexigibilidade devem incluir a motivação anormal da vontade que foi determinada por condições sociais adversas $^{367}$.

Este mesmo autor especifica que, em relação aos delitos de cunho patrimonial, a abertura do conceito de inexigibilidade, de forma que este se mostrasse atento às reais condições de vida do delinquente, configuraria uma alternativa à redução a criminalização por estigma de classe $\operatorname{social}^{368}$.

Em relação aos crimes econômicos, a circunstância "dificuldade econômica" opera como causa exculpante.

\footnotetext{
${ }^{367}$ SANTOS, Juarez Cirino dos. Teoria do Crime. São Paulo: Acadêmica, 1994, p. 71.

${ }^{368}$ SANTOS, Juarez Cirino dos. A moderna teoria do fato punível. Curitiba: Lumen Juris, 2005, p. 269.
} 
Salo de Carvalho ${ }^{369}$ sustenta que, assim como é possível afirmar que a ação do sujeito é fomentada ou potencializada pelo Estado, na esfera dos crimes econômicos, as diretrizes da política econômica podem suscitar ações lesivas ao patrimônio público constatadas na forma de crimes tributários, previdenciários, contra as relações de consumo, entre outros.

Nesses tipos de delito, verifica-se a coculpabilidade por parte da União, dos Estados, dos Municípios através de suas ações ou omissões no âmbito da gestão das políticas econômicas.

$\mathrm{O}$ autor conclui que se demonstrado o nexo de causalidade entre a omissão estatal e a conduta lesiva, seja em relação aos crimes patrimoniais ou em relação aos crimes econômicos, aplica-se o princípio da coculpabilidade e, dependendo do grau de afetação, ele pode incidir tanto na teoria do delito, excluindo a culpabilidade e, consequentemente, o crime, quanto na teoria da pena como causa de diminuição ${ }^{370}$.

Isto porque no processo de identificação da responsabilidade que o sujeito possui em relação ao fato criminoso a culpabilidade atua qualitativamente, de modo que pode até mesmo vir a excluir o crime se algum de seus elementos não se fizer presentes, ao passo que na fase de aplicação da pena a culpabilidade vai atuar como elemento quantificador, respondendo quão culpável era o indivíduo no momento do fato ${ }^{371}$.

Para que uma ação possa ser considerada culpável não basta que um sujeito capaz tenha previsto e desejado o evento lesivo, mas é necessário também que a sua vontade fosse apta a determinar-se normalmente em relação à ação e essa determinação normal não pode exigir-se quando as condições de fato em que o indivíduo atua são de molde a tornar impossível ou muito menos difícil a formação de um querer imune de defeitos ${ }^{372}$.

Leciona Heleno Claudio Fragoso acerca das excludentes de culpabilidade que não há reprovabilidade se na situação em que se encontrava o sujeito não lhe era exigível comportamento diverso; exclui-se a culpabilidade naqueles casos em que o agente cede à presença de circunstâncias ou motivos excepcionais que tornam inexigível comportamento diverso $^{373}$.

\footnotetext{
${ }^{369}$ CARVALHO, Salo de. A co-responsabilidade do Estado nos crimes econômicos: fundamentos doutrinários e aplicabilidade judicial. Porto Alegre: Livraria do Advogado, 2008, p. 145.

${ }^{370}$ Idem.

371 Idem, p. 146.

372 DOTTI, René Ariel. Op.cit., p. 349.

${ }^{373}$ FRAGOSO, Heleno Cláudio. Lições de Direito Penal. 16.ed. Rio de Janeiro: Forense, 2003 , p. 210.
} 
No mesmo sentido e salientando a importância das excludentes de culpabilidade, inclusive das causas supralegais de exculpação, Francisco de Assis Toledo ${ }^{374}$ assegura que se trata a inexigibilidade de outra conduta a primeira e mais importante delas, constituindose um verdadeiro princípio de Direito Penal.

Este autor enaltece que, quando se baseia a inexigibilidade de conduta diversa em preceitos legislados, diz-se constituir uma causa legal de exculpação; entretanto, se baseada estiver em situações extraordinárias não legisladas, diz-se constituir uma causa supralegal; contudo, não perde o caráter de princípio fundamental que se encontra intimamente relacionado com a responsabilidade pessoal, motivo pelo qual dispensa a existência de normas expressas a seu respeito ${ }^{375}$.

Isso significa que para se configurar a culpabilidade do agente, deve-se ater que as condições nas quais ele agiu para cometer o crime também sejam dotadas de normalidade; assim sendo, havendo indício de anormalidade nas condições, a culpabilidade restará prejudicada $^{376}$.

Consiste a exigibilidade de conduta diversa ou de obediência ao Direito na expectativa social de que o agente adotasse um comportamento diferente daquele que desempenhou; desta feita, será exigível da pessoa do delinquente uma conduta diversa quando a coletividade podia esperar dele que tivesse agido de outra forma, adotando comportamento outro que não o cometimento do ilícito ${ }^{377}$.

Assim sendo, para considerar alguém como culpado da prática de um crime, faz-se necessário que a infração penal tenha ocorrido em condições e circunstâncias normais, porque, se assim não for, não será possível exigir da pessoa do delinquente a conduta diversa no sentido de obedecer ao Direito $^{378}$.

Segundo Giuseppe Bettiol ${ }^{379}$, de acordo com a concepção normativa, a culpabilidade desaparece todas as vezes que, devido às circunstâncias, não se puder esperar do sujeito ativo um comportamento diverso daquele comportamento criminoso que ele adotou.

Se determinada conduta criminosa não se configurar reprovável simplesmente por não ser exigível outra conduta por parte daquela pessoa naquelas condições fáticas, a punição também não faz devida, de acordo com o princípio de que não há pena sem culpa.

\footnotetext{
374 TOLEDO, Francisco de Assis. Princípios básicos de Direito Penal. 5.ed. São Paulo: Saraiva, 1994, p. 328.

375 Idem.

${ }^{376}$ Idem.

${ }^{377}$ CAPEZ, Fernando. Curso de Direito Penal. Vol.1. 7. ed. São Paulo: Saraiva, 2004, p. 308.

${ }^{378}$ Idem.

${ }^{379}$ BETTIOL, Giuseppe. Direito Penal. São Paulo: Revista dos Tribunais, 1971, p.140.
} 
De acordo com este raciocínio, plausível de adoção a teoria de inexigibilidade como causa supralegal de exclusão da culpabilidade ${ }^{380}$.

Quem postula em favor do reconhecimento das causas supralegais de exculpação o faz calcado no fato de lacunas existem em todo o Direito Positivo, afetando também o Direito Penal. Quando se constata que a omissão legislativa recai em norma penal não incriminadora e que a reserva legal não obsta, há a possibilidade de se suprir eventual falha por intermédio do disposto no artigo $4^{\circ}$ da Lei de Introdução ao Código Civil ${ }^{381}$, isto é, por uso da analogia, dos costumes e dos princípios gerais de direito.

Desta feita, diante de uma situação específica, poderá o juiz absolver o infrator com base nos critérios dispostos em referido artigo e sob o que eventualmente se fundamentar a inexigibilidade. Com isso, o juiz confere aplicabilidade a uma causa supralegal de exclusão da culpabilidade (o princípio da inexigibilidade de conduta diversa), julgando improcedente a pretensão punitiva do Estado e proferindo o decreto absolutório com fulcro no artigo 386, inciso VI, do Código de Processo Penal ${ }^{382}$.

Uma dessas hipóteses se vislumbra com o problema evidente da incompetência do Estado em fornecer os meios necessários à subsistência material digna do seu povo, tal qual o alto índice de desemprego ${ }^{383}$.

Indaga-se se um cidadão sem trabalho e sem meios materiais para garantir sua subsistência deve aguardar sua morte física em razão da falta de ajuda estatal. Ora, se o Estado não cumpre com sua finalidade constitucional de assegurar o bem estar da sua população, não pode pretender punir alguém que passa a vender mercadorias estrangeiras como forma de subsistência ${ }^{384}$.

Por todo o exposto, há de se cogitar que a inexigibilidade de outra conduta faz-se apta a excluir a culpabilidade penal; condutas como a de condenar um cambista, por exemplo, somente endossa que um indivíduo sem representação econômica e sem trabalho, em um Estado ausente na regulação da distribuição adequada de renda, haverá de se

\footnotetext{
${ }^{380}$ OLIVEIRA FILHO, Mário de. Temas Atuais de Advocacia Criminal. São Paulo: Etna, 1996, p.190.

${ }^{381}$ Art. $4^{\circ}$ da Lei de Introdução ao Código Civil Brasileiro. Quando a lei for omissa, o juiz decidirá o caso de acordo com a analogia, os costumes e os princípios gerais de direito.

382 Artigo 386 do Código de Processo Penal Brasileiro. O juiz absolverá o réu, mencionando a causa na parte dispositiva, desde que reconheça: V. VI - existirem circunstâncias que excluam o crime ou isentem o réu de pena (arts. 20, 21, 22, 23, 26 e $\S 1^{\circ}$ do art. 28, todos do Código Penal), ou mesmo se houver fundada dúvida sobre sua existência; (Alterado pela Lei n. 11.690-2008).

${ }^{383}$ SOBRINHO, José Wilson Ferreira. Repertório IOB de Jurisprudência. São Paulo: 23/1995, p. 370.

${ }^{384}$ Idem.
} 
conformar com tal situação até que o quadro desfavorável se reverta, o que, dificilmente acontecerá $^{385}$.

Este enfoque dado à inexigibilidade de conduta diversa corrobora a busca por um sistema penal calcado no garantismo, que alcance a justiça social pela humanização da prática punitiva, ou seja, que se faça sensível à realidade do mundo fenomênico, uma vez que o Direito, por ser uma ciência social, deve estar em constante mutação e não estático, a fim de acompanhar o processo evolutivo pelo qual a sociedade se transforma continuamente.

Assevera Leonardo Isaac Yarochewsky que o ponto crucial para o reconhecimento da inexigibilidade de outra conduta como causa de exclusão da culpabilidade é precisar se, no momento dos fatos, o agente podia ou não agir de outro modo, ou seja, se quando da prática da conduta era-lhe ou não exigido um comportamento conforme o Direito. Por sua vez, o Direito Penal moderno não se atém ao excessivo formalismo ou a uma rigidez de conceitos que acaba por afastar o homem da realidade e, por este paradigma atual, não se admite mais possível que o Direito Penal deixe de reconhecer e admitir a inexigibilidade de outra conduta como causa de exclusão da culpabilidade ${ }^{386}$.

Também nesse sentido, Claudio Brandão expõe que a ideia de exigibilidade de outra conduta se atrela à ideia de liberdade, uma vez que se reprova pessoalmente o sujeito que, mesmo estando apto a se comportar conforme o Direito, optou livremente por adotar um comportamento contrário ${ }^{387}$.

No que tange à estreita relação entre o dever e o poder que se vislumbra ao abordar a inexigibilidade de conduta diversa, Leonardo Isaac Yarochewsky considera que o juízo de reprovação da conduta somente recairá sobre o autor imputável de certo fato ilícito, ou seja, sobre a pessoa que podia e devia agir conforme o Direito; desta feita, se o autor de um fato definido em lei como crime, apesar de ser imputável e devendo teoricamente agir conforme o Direito, mas, diante das circunstâncias que ultrapassam os limites do homem médio, não pôde agir em consonância com o ordenamento, reconhecer-se-á a inexigibilidade de conduta diversa, excluindo sua culpabilidade ${ }^{388}$.

Heinrich Henkel considera a inexigibilidade de outra conduta uma causa da inculpabilidade pura, ou seja, nega-se a culpabilidade do agente por conta de não se

\footnotetext{
${ }^{385}$ Idem, p. 371.

${ }^{386}$ YAROCHEWSKY, Leonardo Isaac. Da Exigibilidade de Conduta Diversa. Belo Horizonte: Del Rey, 2000, p. 39 e 40.

${ }^{387}$ BRANDÃO, Claudio. Curso de Direito Penal. Rio de Janeiro: Forense, 2008, p. 231.

${ }^{388}$ YAROCHEWSKY, Leonardo Isaac. Op.cit., p.39.
} 
caracterizar nenhuma formação jurídica defeituosa, por haver mácula no juízo de censura sobre o autor do fato e, dessa forma, resta ausente a reprovação que é o conteúdo normativo da culpabilidade ${ }^{389}$.

Por isso, segundo o autor, a exigibilidade de obediência ao Direito deve ser entendida como pressuposto dos elementos da imputabilidade e da potencial conhecimento da ilicitude do fato, porque sem que haja o juízo de reprovabilidade sobre o sujeito infrator estará ausente sua culpabilidade, e, como dito anteriormente, a reprovabilidade do fato estará condicionada à questão de se o autor do fato acaba agindo de modo contrário pela incidência de circunstâncias externas que tornam a conduta diversa da criminosa inexigível, mesmo possuindo o dever de agir conforme o Direito ${ }^{390}$.

Disso se depreende que a inexigibilidade de conduta diversa pode ser considerada causa geral de exclusão da culpabilidade que será reconhecida ante os fatos não abrangidos pelas causas de exculpação previstas na lei; entretanto, para que isso ocorra e a fim de que o sujeito seja eximido da responsabilidade penal, faz-se necessário comprovar que, no caso concreto, ele não pôde atuar conforme a norma.

Nesse mesmo sentido é o entendimento de Felipe Cazuo Azuma, para quem a inexigibilidade exerce a função de fundamento geral de exculpação, ou seja, revela-se o fundamento do juízo de reprovabilidade do fato, tanto que todos os casos de exculpação são assim considerados porque, ante as circunstâncias, acaba-se por não exigir do transgressor da norma um comportamento de acordo com o Direito ${ }^{391}$.

Causa supralegal de exclusão da culpabilidade pode ser entendida como aquela que, embora não esteja prevista expressamente em um dispositivo legal, pode ser aplicada com fundamento nos princípios constitucionais que baseiam todo o ordenamento jurídico; frisase que, a lei penal brasileira não veda a utilização do argumento da inexigibilidade de conduta diversa como causa supralegal de exclusão da culpabilidade. Assim, quando o agente não agiu em conformidade com o Direito por impossibilidade oriunda da presença de circunstâncias fáticas que fariam com que qualquer ser humano agisse da mesma maneira diante das mesmas, estará configurada a inexigibilidade de conduta diversa ${ }^{392}$.

Desse modo e como já mencionado, a inexigibilidade de outra conduta fundamenta a configuração de todas as hipóteses de exculpantes, pois, quando ausente a capacidade de o

\footnotetext{
${ }^{389}$ HENKEL, Heinrich. Exigibilidad e Inexigibilidad Como Princípio Jurídico Regulativo. Buenos Aires: Editorial B de F, 2005, p.123.

${ }^{390}$ Idem.

${ }^{391}$ AZUMA, Felipe Cazuo. Inexigibilidade de Conduta conforme a Norma. Curitiba: Juruá, 2007, p. 83.

${ }^{392}$ GRECO, Rogério. Curso de Direito Penal - Parte Geral. Rio de Janeiro: Impetus, 2009, p. 420.
} 
indivíduo se autodeterminar de acordo com a lei, será a conduta diversa inexigível e, por conseguinte, restará afastada a culpabilidade do agente em relação à conduta criminosa praticada.

Pode-se afirmar, então, que se dará a inexigibilidade de conduta diversa quando não se vislumbrar a presença de um dos elementos constitutivas da culpabilidade enquanto elemento do crime, quais seja, a imputabilidade, a potencial conhecimento da ilicitude e a exigibilidade de obediência ao Direito.

Nitidamente é impossível para qualquer ordenamento jurídico prever e positivar todas as situações fáticas sobre as quais as normas incidirão, sendo necessário, portanto, tornar o Direito mais dinâmico e, no caso do Direito penal, existe a premente necessidade de se humanizar a pena e efetivar a máxima de ultima ratio.

As situações de anormalidade em que o sujeito é impedido de atuar conforme o "dever ser" normativo e que acabam não taxadas no ordenamento realmente existem, entretanto, o fato de nem todas as hipóteses fáticas estarem descritas em lei não pode impedir de se reconhecer uma causa de exculpação quando o próprio caso esclarece que não é dado exigir certo comportamento.

Afirma Felipe Cazuo Azuma que, dependendo do caso concreto, pode ocorrer de o autor do fato não ter a possibilidade de cumprir seu dever jurídico, em razão da anormalidade da situação. Ora, o Direito exige que todo sujeito imputável, que tem capacidade de culpabilidade, norteie seus atos conforme o entendimento de lícito e ilícito que possui. Entretanto, existem casos em que não se exige do agente um comportamento conforme o Direito, por causa da motivação anormal de sua vontade que se originou de circunstâncias alheias à normalidade ${ }^{393}$.

Claus Roxin considera que tanto aquele que é incapaz de compreender o caráter ilícito do fato quanto aquele indivíduo que não está momentaneamente em condições de agir segundo esta compreensão, carecem de idoneidade para serem destinatários das normas e, assim, tanto a falta de capacidade de compreensão, quanto à de autocontrole e orientação podem ser tidas como casos em que o autor não consegue assimilar a ordem contida na norma ${ }^{394}$.

\footnotetext{
${ }^{393}$ AZUMA, Felipe Cazuo. Op.cit., p. 86.

${ }^{394}$ ROXIN, Claus. A culpabilidade e sua Exclusão no Direito Penal. In: Revista Brasileira de Ciências Criminais. São Paulo: Revista dos Tribunais, 2004, p.57.
} 
Tem-se, então, que a inexigibilidade de conduta diversa se apresenta como uma alternativa para o Direito Penal e aproxima os destinatários da norma incriminadora da justiça social que deve servir a todos, tornando-os iguais em dignidade.

Vislumbra-se, então, que o princípio da coculpabilidade tal qual foi aplicado em referida decisão monocrática da comarca de Marília SP, pode ser um exemplo de causa supralegal de exculpação. Isso obrigada o julgador que se deparar com o pleito de reconhecimento desta tese analisar mais atenciosamente todas as circunstâncias fáticas e de caráter pessoal que circundam também o autor do fato.

Entretanto, mesmo considerando-o causa supralegal de exculpação, existe a necessidade premente de tornar o princípio da coculpabilidade uma causa legal de exculpação, haja vista, pelo que se denota da análise dos julgados, existe profundo receio por parte dos julgadores em aplicar, ainda que, hoje em dia, como uma simples circunstância atenuante, um instituto que não está expressamente previsto em lei.

\section{3 - Alguns acórdãos contrários ao princípio da coculpabilidade}

Da pesquisa jurisprudencial realizada no presente estudo, além dos acórdãos já apresentados acerca da aplicabilidade do princípio da coculpabilidade, foi possível encontrar decisões que sequer reconhecem o tema como pertinente ao ordenamento pátrio.

Em nível de ilustração menciona-se um acórdão ${ }^{395}$ do Tribunal de Justiça de São Paulo em que se apresenta a linha mais seguida pelos desembargadores paulistas no sentido de não entenderem o princípio da coculpabilidade como vigente e tampouco que este possua consonância com a ordem jurídica brasileira.

Extrai-se do voto do Relator a parte em que o tema em estudo é abordado:

"Sobre a tese defensiva da coculpabilidade, penso que não merece acolhida. Tal tese, construída pela doutrina, não encontra agasalho na legislação pátria nem eco na jurisprudência de nossos tribunais. Reconhecer genericamente

\footnotetext{
${ }^{395}$ Tribunal de Justiça do Estado de São Paulo. $5^{\text {a }}$ Câmara Criminal. Relator: Souza Nery. Comarca de Origem: São Vicente. Data: 12/04/2012. Revisão criminal n. 0058035-07.2010.8.26. Inversão do ônus da prova. Em sede revisional, posto que o requerente tem contra si uma decisão condenatória transitada em julgado, inverte-se o ônus da prova, resolvendo-se, daí, a eventual dúvida existente segundo a máxima in dubio pro societate. Penal. Reincidência considerada em primeira instância para fins de agravar a pena do agente. Alegação de bis in idem. Pleito defensivo de afastamento da agravante. Improcedência. A reincidência deve ser considerada justamente para uma melhor individualização da pena. Penal. Defesa que sustenta em seu pedido revisional tese de coculpabilidade, visando à redução da sanção. Impossibilidade. Tal tese, construída pela doutrina, não encontra agasalho na legislação pátria nem eco na jurisprudência de nossos tribunais.
} 
uma culpa concorrente do Estado num crime cometido por um de seus cidadãos representaria, parece-me, um retrocesso na proposta hodierna que visa à emancipação do homem, que o humanismo quer autônomo (ideal iluminista) e responsável pelos seus atos. Todos sabem que o Poder Público vem se esforçando bastante para dar conta da grande demanda social. $O$ Leviatã - gostemos ou não de dizêe-lo - não é tão todo poderoso assim. Ele vem atendendo à população nas suas legítimas necessidades (saúde, educação, segurança pública etc.) só na medida das suas possibilidades. É a realidade possivel na atual conjuntura. Apesar disso, muitas pessoas, carentes que sejam, (sobre) vivem com dignidade dentro da legalidade e licitude. Antes de prevenir e reprimir o crime, a pena reduzida pela coculpabilidade imposta ao agente poderia ser origem de inconformismos e de revolta contra a ordem estabelecida, o que não convém. A respeito, trago à colação magistério de Guilherme de Souza Nucci: 'Não nos parece correta essa visão. Ainda que se possa concluir que o Estado deixa de prestar a devida assistência à sociedade, não é por isso que nasce qualquer justificativa ou amparo para o cometimento de delitos, implicando em fator de atenuação da pena. Aliás, fosse assim, existiriam muitos outros "coculpáveis" na rota do criminoso, como os pais que não cuidaram bem do filho ou o colega na escola que humilhou o companheiro de sala, tudo a fundamentar a aplicação da atenuante do art. 66, do Código Penal, vulgarizando-a. Embora os [muitos] exemplos narrados [pelos defensores do instituto] possam ser considerados como fatores de impulso ao agente para a prática de uma infração penal qualquer, na realidade, em última instância, prevalece a sua própria vontade, não se podendo contemplar tais circunstâncias como suficientemente relevantes para aplicar a atenuante. Há de existir uma causa efetivamente importante, de grande valor, pessoal e específica do agente e não comum a inúmeras outras pessoas, não delinquentes, como seria a situação de pobreza ou de descaso imposto pelo Estado, para implicar na redução da pena (Nucci, Guilherme de Souza. Código Penal Comentado. São Paulo: RT, 2010, p. 235)'. Penso que o princípio da isonomia, constitucionalmente consagrado, por pressupor a constatação de diferenças entre os cidadãos, longe de obrigar à redução da pena do delinqüente que cresceu desassistido ou desamparado, deve justificar, isto sim, a majoração da sanção devida àqueles que tiveram toda a 
oportunidade de sucesso na vida e que, malgrado isso, preferiram a incursão no mundo do crime. Casos desse tipo emblemáticos - de pessoas abastadas e de políticos bem sucedidos aparecem na mídia de tempos em tempos. Quero crer que a culpabilidade destes é muito maior do que a daqueles, a justificar, com isso, a majoração da pena base. Uma conhecida máxima pode bem explicar a orientação aqui proposta: a quem mais foi dado, dele mais se exigirá. Some-se a tudo que nossos tribunais têm seguidamente afastado a tese da coculpabilidade, conforme demonstram os seguintes julgados abaixo selecionados:

Impossível acolher-se a teoria da Co-Culpabilidade para mitigar a reprovação da conduta do agente no caso, pois além de essa matéria não ter sido analisada pelo Tribunal de origem, o que impediria a sua apreciação diretamente por esta Corte Superior de Justiça, diante das circunstâncias em que se deram os ilícitos, não há como se eximir o acusado parcialmente das suas consequências, tampouco como concluir que teria sido levado a delinquir por uma suposta ausência de um direito não concretizado pelo Estado ou porque teria menor âmbito de autodeterminação em razão de eventuais condições sociais desfavoráveis pela teoria da co-culpabilidade concebida por Zaffaroni. (STJ, HC 116972 / MS).

Mencionada teoria compartilha com a sociedade a responsabilidade criminal por ato de indivíduos que não obtiveram do Estado a observância plena de seus direitos e garantias fundamentais assegurados pela Constituição da República de 1988, acarretando deficiência na capacidade de autodeterminação perante os bens juridicamente assegurados. Essa premissa não poder ser levada nesse aspecto, partindo-se do pressuposto que a origem da criminalidade encontrasse, em tese, na pobreza. Esse entendimento viola o princípio da isonomia. Em realidade, a invocada teoria traz o Estado e a sociedade, em razão de suas omissões, como vetores ainda que indiretamente dos atos ilícitos. Busca explicar um fenômeno social em razão de uma perspectiva apenas mesmo que considerável, quando na verdade trata-se de uma complexidade de variantes que concorrem para aqueles resultados. Pertinente colacionar os esclarecimentos de René Ariel Dotti: “As normas, sob a perspectiva sociológica, são regras culturais que associam o comportamento ou a aparência do indivíduo a recompensas ou sanções. Consideradas em seu 
conjunto, elas constituem o sistema regulador das atividades individuais, ou, como diria SCHAEFFLE, com uma feliz metáfora, "o sistema nervoso da sociedade”. Em seu ambiente natural e comunitário, o homem encontra-se envolvido por uma rede de "relações necessárias que derivam da natureza das coisas" como afirmou MONTESQUIEU. Algumas delas são de ordem física e fisiológica, outras de ordem social e espiritual, que ele procura conhecer para aceitar ou rejeitar os seus efeitos conforme lhes sejam úteis ou nocivas. Como acentua GROPPALI, é no meio dessas forças, baseado nos elementos que lhe fornecem os sentidos, iluminados pela razão e sob o impulso dos sentimentos $e$ das crenças, chocando contra a atividade concorrente dos seus semelhantes, o homem se movimenta e age em busca do seu bem estar e felicidade. Assim, por necessidade das próprias coisas e devido ao conflito das atividades individuais, a conduta humana é submetida a determinadas regras para não prejudicar ao próximo e à coletividade. O homem, portanto, move-se no meio de todo um conjunto de normas, de costumes, de usos, de hábitos, de regras de cortesia as quais regulam até os mais insignificantes atos da vida para estabelecer como ele deve se comportar" (DOTTI, René Ariel. Curso de direito penal : parte geral. 3. ed. rev., atual. e ampl. São Paulo: Editora Revista dos Tribunais, 2010. p. 70). Nesse sentido, em seus depoimentos, ainda que informalmente, ambos os apelantes trabalhavam. Portanto, tinham consciência da forma justa de ter acesso a riquezas.

Saliente-se que, da própria exposição de motivos da Parte Geral do Código Penal, a política criminal adotada é orientada para a proteção da sociedade, reservando-se a pena privativa de liberdade aos casos de efetiva necessidade.

Ademais, as constantes evoluções do Direito Penal trouxeram as penas restritivas de direitos e as alternativas às penas, considerando a Política Criminal adotada pelo legislador pátrio. Assim, a culpabilidade é elemento que já fora levada em consideração pelo Legislativo tendo em vista a desigualdade existente em qualquer nação. Nesse sentido, a doutrina de Jorge de Figueiredo Dias: “\$70 Se a retribuição não tem qualquer palavra a dizer em matéria e finalidades da pena, a ela pertence, segundo a sua história e segundo o seu conteúdo (como acima se acentuou já), o mérito indeclinável de ter posto em evidência a essencialidade do princípio da culpa e do significado deste para o problema das finalidades da pena. Segundo aquele princípio "não 
há pena sem culpa e a medida da pena não pode em caso algum ultrapassar a medida da culpa”.

Junto ao Tribunal de Justiça do Estado de Goiás também é possível encontrar um acórdão ${ }^{396}$ que não reconhece a incidência do princípio.

Atentando para a parte do voto na qual o Relator analisa a possibilidade ou não de incidência do princípio, tem-se:

Entendo não ser cabível a atenuação pretendida em face da suposta miserabilidade vivida pelo apelante e da coculpabilidade do Estado aventada. Em que pese o artigo 66 do Código Penal possibilitar ao sentenciante atenuar a pena em face de circunstância, anterior ou posterior ao crime, não prevista expressamente em lei, não é qualquer circunstância que indica uma menor culpabilidade do agente, mas aquelas relevantes. No caso em análise, quando ouvido em juízo, o apelante disse ter estudado até a $3^{a}$ série do ensino fundamental, trabalhar como auxiliar na furação de poço artesiano e que se encontrava trabalhando já há um ano e três meses. Aduziu, ainda, não ter tido pai, que foi criado na rua e que no dia dos fatos havia feito uso de bebida alcoólica e cheirado tiner. Da assertiva do apelante, não vejo configurada a suposta miserabilidade aventada capaz de ensejar uma atenuação na reprimenda imposta. O apelante afirmou ter fugido de casa e passado a viver nas ruas, porque era maltratado pelo padrasto, sendo acolhido em uma igreja, onde aduziu ter permanecido internado por três anos, local onde estudava, trabalhava e lutava caratê. Assim, a invocação da teoria da co-culpabilidade além de não encontrar amparo legal, não restou comprovada e, mesmo que houvesse sido positivada, tal fato por si só não faz nascer qualquer justificativa ou amparo para o cometimento de delitos. Leciona Guilherme de Souza Nucci (Código Penal Comentado, 8. ed. - São Paulo: Editora Revista

\footnotetext{
${ }^{396}$ Tribunal de Justiça do Estado de Goiás. Primeira Turma Julgadora da Primeira Câmara Criminal. Apelação n. 36357-7/213. Original da comarca de Goiânia. Relator Desembargador Huygens Bandeira de Melo. Data do acórdão - 03/12/2009. Ementa: APELAÇÃO CRIMINAL. ROUBO. DIMINUIÇÃO DO QUANTUM DE PENA IMPOSTA. NÃO CABIMENTO. ATENUANTE INOMINADA. MISERABILIDADE E CO-CULPABILIDADE DO ESTADO. NÃO CONFIGURADA. ALTERAÇÃO REGIME INICIAL CUMPRIMENTO DE PENA. NÃO CABIMENTO. RÉU REINCIDENTE. 1 - Não incorrendo o sentenciante em nenhum erro, equívoco ou exacerbamento, inviável a redução do quantum de pena imposta. 2 - A miserabilidade, não comprovada, por si só, não possibilita o reconhecimento da atenuante inominada e da co-culpabilidade do Estado, tornando-se necessário para sua aplicação que se trate de circunstância relevante, pessoal e específica para o agente. 3 - O regime de cumprimento da pena deve ser o inicial fechado quando imposta reprimenda superior a quatro anos e se trate de réu reincidente. Apelação conhecida e desprovida.
} 
dos Tribunais, 2008, p. 227): 'fosse assim, existiriam muitos outros coculpáveis na nota do criminoso, como os pais que não cuidaram bem do seu filho ou o colega na escola que humilhou o companheiro de sala, tudo a fundamentar a aplicação da atenuante do art. 66 do Código Penal, vulgarizando-a. (...) Há de existir uma causa efetivamente importante, de grande valor, pessoal e específica para o agente - e não comum a inúmeras pessoas, não delinquentes, como seria a situação de pobreza ou o descaso imposto pelo Estado - para implicar na redução da pena. Ressalte-se que os próprios autores que defendem sua aplicação admitem não possuir essa circunstância sustentação no texto legal do Código Penal'. No mesmo sentido a jurisprudência anotada: 'CO-CULPABILIDADE DO ESTADO NÃO RECONHECIDA. AUSÊNCIA DE PREVISÃO LEGAL. Esta teoria carece de sustentação, pois se embasa na afirmação de que a sociedade tem parcela de culpa pelos crimes cometidos por seus membros que passam por dificuldades financeiras. Desta forma, países em desenvolvimento, como o Brasil, que possuem condições econômicas desfavoráveis, sempre estariam contribuindo para prática de atos delituosos. A teoria da co-culpabilidade desencadearia uma situação de impunidade que não deve ser admitida no sistema legal. (Apelação Crime $N^{o}$ 70021747985, Sétima Câmara Criminal, Tribunal de Justiça do RS, Relator: Naele Ochoa Piazzeta, Julgado em 15/05/2008)'. 'Inaplicável o reconhecimento da atenuante genérica do artigo 66 do Código Penal (teoria da co-culpabilidade do Estado), eis que a jurisprudência tem entendido que a pobreza, baixa escolaridade e o descaso do Estado não são fatores determinantes para justificar a criminalidade. (Apelação Crime $N^{o}$ 70027898212, Terceira Câmara Criminal, Tribunal de Justiça do RS, Relator: Elba Aparecida Nicolli Bastos, Julgado em 19/02/2009)'. 'A concessão do benefício da atenuante inominada prevista no artigo 66 do Código Penal somente é possível quando o agente tenha praticado, antes do evento, ou depois, ato meritório que lhe confira relevância, o que não é o caso. (TJ/GO, $2^{a}$ Câmara Criminal, DJ 146 de 05/08/2008, Rel. Des. Paulo Teles)’. Assim, não vejo nenhuma circunstância capaz de ensejar a atenuação da pena imposta, sendo insuficiente para tanto a assertiva não comprova de miserabilidade, eis que ao cometer o delito, o apelante não o fez em consequência da alegada precária condição econômica. 
Neste julgado, o Relator manifestou seu entendimento pela não pertinência da teoria da coculpabilidade já na primeira abordagem à questão.

Ao fundamentar seu voto, valeu-se de uma doutrina que alerta para a aplicação da teoria da coculpabilidade com parcimônia e não de forma indiscriminada; bem como de julgados que negaram aplicação ao princípio, mas que se mostraram divergentes nos argumentos, pois, enquanto dois deles negava a concessão da atenuação por falta de provas da incidência da circunstância no caso concreto, o outro negava o próprio princípio, sustentando a falta de amparo legal.

Por ser um assunto novo no Brasil, cujo raciocínio ainda está sendo construído, percebe-se que a maioria das decisões dos Tribunais menciona a necessidade de se ler o princípio com cautela.

Em um acórdão ${ }^{397}$ do Tribunal de Justiça do Estado de Minas Gerais, o Relator menciona em seu voto o parecer do Procurador Geral de Justiça que chama a atenção pelo modo veemente com que se opõe à ideia da coculpabilidade:

"Não há que se cogitar também em absolvição com fulcro na tese de coculpabilidade do Estado, da Sociedade, já que o réu tinha pleno conhecimento de que seu ato é contrário a lei, é um crime, mas ao invés de tentar trabalhar honestamente, optou por cometer um crime, obter recursos em detrimento do prejuízo alheio, visou o lucro fácil, sem tem que assumir responsabilidades que um labor lícito lhe impõe. Nos dizeres do i. Procurador de Justiça, Dr. Carlos Weber Veado, também entendo que: 'Ora, colocar a sociedade como coautora da prática da conduta criminosa é totalmente temerária ao dividir as responsabilidades dos cidadãos com o meio em que vive. Colocar-se como vítima da sociedade, essa como o algoz de todos os

\footnotetext{
397 Tribunal de Justiça do Estado de Minas Gerais. Primeira Câmara Criminal. Apelação n. 1.0699.09.094289-6/001. Comarca de Origem: Ubá. Relator: Desembargador Delmival de Almeida Campos. Data do acórdão: 24/08/2010. Ementa: DIREITO PENAL - CRIME DE FURTO QUALIFICADO TENTADO - DESTRUIÇÃO OU ROMPIMENTO DE OBSTÁCULO - 'RES FURTIVA' - NEGATIVA DE AUTORIA ISOLADA NO CONJUNTO PROBATÓRIO - DEMAIS PROVAS EM SENTIDO OPOSTO AO QUE O RÉU ALEGOU - CADERNO PROBATÓRIO DOS AUTOS - ACERTO DA CONDENAÇÃO HAVIDA - TESE DEFENSIVA - COCULPABILIDADE DA SOCIEDADE OU DO ESTADO IMPOSSIBILIDADE DE RECONHECIMENTO - AUSÊNCIA DE PREVISÃO LEGAL - RÉU QUE OPTOU PRATICAR O DELITO POR SUA LIVRE E ESPONTÂNEA VONTADE - CIÊNCIA DE QUE O ATO É CONTRÁRIO A LEI - INTENÇÃO DE LUCRO FÁCIL E COM ESFORÇO MÍNIMO - FURTO PRIVILEGIADO - NÃO RECONHECIMENTO - DESVALOR DA CONDUTA - ACUSADO REINCIDENTE - MAUS ANTECEDENTES - PENA APLICADA - CRIME TENTADO - ACERTO DA SENTENÇA - GRATUIDADE DE JUSTIÇA - QUESTÃO LIGADA À EXECUÇÃO DA PENA. Constatando-se a demonstração suficiente da autoria e materialidade dos delitos, a condenação do réu mostra-se mesmo de rigor.
} 
desassistidos pela sorte é, no mínimo, a faceta de cinismo em pretender dividir a má conduta com os cidadãos pobres ou ricos, trabalhadores e honestos, que enfrentam todas as dificuldades materiais mas incapazes de transgredir. Portanto, a ação criminosa do apelante é típica e antijurídica, pois nenhuma causa de exclusão de criminalidade o favorece'.”.

Nitidamente o Relator e o Procurador do caso acima vislumbram o princípio da coculpabilidade como algo absolutamente inconcebível. Pelo curto trecho do acórdão no qual o Relator analisa o pedido de reconhecimento da coculpabilidade como circunstância atenuante, nota-se a falta argumentação jurídica na decisão e se fica com a impressão de que a negativa se deu ante uma leitura açodada do tema que gerou apenas um discurso inflamado, porém superficial; tanto porque, em momento algum, o Relator analisa a aplicabilidade do princípio, tampouco sua compatibilidade com o ordenamento jurídico; diferentemente do que ocorreu em outros acórdãos analisados, que também não reconheceram a incidência do princípio da coculpabilidade, mas que o fizeram mediante o desenvolvimento de uma linha de raciocínio plausível e de um estudo do tema que teria conduzido os julgadores à conclusão da não aplicabilidade do princípio.

\section{4 - A culpabilidade por vulnerabilidade}

Diante de negatórias tão veementes, Eugenio Raul Zaffaroni ${ }^{398}$ visualizou a crise conceitual pela qual passam certos elementos do Direito Penal e encarou a situação de deslegitimação que essa situação encerra sobre o próprio Direito Penal enquanto mecanismo de controle social que deve se ater às premissas constitucionais de primazia ao ser humano. Suas reflexões culminaram na análise da culpabilidade sob um novo aspecto, a vulnerabilidade.

O ponto de partida foi o fato de que os sistemas punitivos atuais exercem o poder de forma descompassada do sistema constitucional de garantis individuais, o que faz da pessoa do delinquente um simples objeto sobre o qual incidirá a pena que, muitas vezes, dissocia-se das noções de liberdade e de responsabilidade individuais.

Esse conceito de responsabilidade individual, na atual dogmática do Direito Penal finalista, se evidencia na culpabilidade, tanto que nele se encontram os requisitos legais que limitam o juízo de reprovação que recai sobre a conduta criminosa e é também sobre a

${ }^{398}$ ZAFFARONI, Eugenio Raúl. Em busca das penas perdidas - a perda de legitimidade do sistema penal. $5^{\mathrm{a}}$. Edição. Trad. Vânia Romano Pedrosa e Amir Lopez da Conceição. Rio de Janeiro: Ed. Revan, 2001. 
culpabilidade que se constituem os discursos punitivos na tentativa de se legitimar o exercício do poder de punir estatal.

Segundo a visão de Eugenio Raul Zaffaroni, também o conceito de culpabilidade enquanto reprovabilidade estará envolvido pela referida crise de legitimação do exercício do poder penal, porque, se o poder punitivo vem a afetar diretamente o indivíduo, então, se ele for exercido de forma "não legítima", assim também será a sua influência sobre a seleção dos sujeitos culpáveis ${ }^{399}$.

De acordo com esse entendimento, quando, para se mensurar a responsabilidade individual, utiliza-se da racionalidade, da consciência ou da eticidade do "homem livre" como critérios, a tendência é que este conceito se transforme em mera abstração, desprovida da efetividade que lhe é necessária na limitação do poder punitivo.

Por esta razão, o sistema penal acaba por institucionalizar a seletividade dos sujeitos e a principal crítica de Eugenio Raul Zaffaroni reside no fato de que se torna totalmente incoerente formular um juízo de reprovação concedendo inteira responsabilidade ao homem a possibilidade de escolha "livre" de seus atos, uma vez que, em um sistema penal cujo signo sinal é esse poder selecionador e criminalizante, obviamente a responsabilidade pela imputação do injusto a alguém é exclusivamente da agência judicial e esta deve responder perante o indivíduo que está sendo processado e a comunidade, como prestação de contas acerca da forma com que exerce ou administra o poder punitivo ${ }^{400}$.

Assim sendo, se o poder já se encontra deslegitimado não é justo que por ele se reprove alguém, principalmente aquelas pessoas que foram selecionadas pela agência judicial.

Isso provoca um esvaziamento do conteúdo da culpabilidade, no que concerne ao seu aspecto ético, porque inclusive ele acaba mitigado pelo processo de criminalização e, segundo o autor em questão, corre-se o risco de permitir uma abertura ainda maior das formas opressoras de poder.

Vale enaltecer que Nilo Batista também demonstra preocupação no sentido de que a teoria do delito ignora que o âmbito de autodeterminação dos sujeitos sociais está diretamente ligado à seleção feita pelo sistema punitivo ${ }^{401}$.

Os caminhos de eticização do Direito Penal parecem ser intransitáveis depois que se constata a deslegitimação sociológica do poder punitivo, por isso a necessidade premente

\footnotetext{
399 Idem, p. 259.

${ }^{400}$ Idem, p. 264.

${ }^{401}$ BATISTA, Nilo. Op.cit., p. 116.
} 
de se efetivar a sempre válida reclamação ética, o que se logrou com a proposta de um novo olhar sobre a culpabilidade tradicional e a reformulação deste conceito no sentido de reorientar o poder ${ }^{402}$.

Desta feita, a atribuição do caráter da eticidade ao Direito Penal que Eugenio Raul Zaffaroni propõe recai sobre a própria agência judicial perante o exercício de poder deslegitimado, ou seja, ao analisar a culpabilidade deveria voltar-se a atenção para a responsabilidade ética agência de controle em face das políticas criminalizantes ${ }^{403}$.

Assim, a intervenção racional da agência judicial não se daria somente com base na culpabilidade pelo injusto, mas no uso racional de seu poder visando à redução progressiva de sua própria violência seletiva e arbitrária.

Dai surge a culpabilidade pela vulnerabilidade como resposta à crise de legitimidade da culpabilidade e à violência criminalizadora.

Essa proposta implica transferir a responsabilidade do homem para as agências judiciais sob um contexto de deslegitimação do poder e a culpabilidade passaria a ter a situação de vulnerabilidade da pessoa (quando o sistema penal a seleciona e a utiliza como instrumento para justificar seu próprio exercício de poder) por fundamento da responsabilidade pelo injusto, de modo que esta não se calcaria mais em aspectos subjetivos individuais, ou seja, é o grau de vulnerabilidade do indivíduo em relação ao sistema penal que decidiria sua seleção e não a realização do injusto.

Em termos mais objetivos, Eugenio Raul Zaffaroni explica o conceito de vulnerabilidade como sendo o risco de as pessoas serem selecionadas pelos processos de criminalização que derivam da arbitrariedade das esferas de poder. Tal situação de vulnerabilidade, que pode se configurar em diferentes níveis, conforme a situação imposta ao indivíduo, geralmente é produzida por dois fatores principais, quais sejam: a posição ou o estado de vulnerabilidade e o esforço pessoal para a vulnerabilidade.

A posição ou estado de vulnerabilidade se determina por agentes condicionantes sociais e está atrelado ao nível de risco ou do perigo sofrido pela pessoa que compõe uma classe, grupo, raça ou cultura; isso significa que, segundo este critério, analisa-se a probabilidade, maior ou menor, de a pessoa ser criminalizada em face de um estigma social. Entretanto, Euugenio Raul Zaffaroni, alerta que a posição ou estado de

\footnotetext{
402 THOREL, Gianpaolo. Contributo ad una etica della colpevolezza. In: Studi sulla colpevolezza, a cura di L. Mazza. Torino, 1990, p. 149.

${ }^{403}$ ZAFFARONI, Eugenio Raúl. Em busca das penas perdidas - a perda de legitimidade do sistema penal. $5^{\mathrm{a}}$. Edição. Trad. Vânia Romano Pedrosa e Amir Lopez da Conceição. Rio de Janeiro: Ed. Revan, 2001, p. 265.
} 
vulnerabilidade não deve aparecer como um fator isolado de limitação do poder punitivo, pois estaria em consonância com a desprezada lógica da culpabilidade de autor ${ }^{404}$.

O esforço pessoal para a vulnerabilidade se revela o fator de maior ênfase, pois, consistindo no grau de risco ou perigo que a pessoa dotada de autonomia se coloca em razão da realização de um comportamento, permite analisar a atuação do indivíduo no âmbito da teoria do injusto, porque, se este comportamento for um crime, resta configurado o esforço para a vulnerabilidade, o que autorizaria, ainda que em última instância, a resposta punitiva da agência judicial ${ }^{405}$.

Há de se observar que existe uma ordem de fatores subjetivos e materiais decididos conscientemente pelo sujeito que constituem a essência da contribuição dada pela pessoa para sustentar o exercício de poder que a seleciona e criminaliza ${ }^{406}$.

É sobre este fator, o esforço pessoal para a vulnerabilidade, que a agência judicial direcionará o foco de sua resposta; nele também a agência encontrará o limite máximo de violência tolerável contra a pessoa, limite este que imporá a redução do seu poder selecionador e, consequentemente, restringirá o espaço de atuação de poder no sistema penal.

A ideia da vulnerabilidade implica ter a pessoa humana como limite instransponível de uma ordem de poder, pois o objetivo de um sistema que se calca em premissas de garantias do cidadão é a defesa intransigente da vida humana principalmente das que passam pelo sistema punitivo.

Por tudo isso, Eugenio Raul Zaffaroni acredita ter resolvido o problema de graduação da responsabilidade individual, pois, segundo ele, essa graduação da vulnerabilidade viabiliza a diferença na abordagem entre situações legais como os delitos econômicos, em que os sujeitos culpáveis partem de uma posição social favorável e escolhem cometer o fato criminoso, e os delitos famélicos por exemplo. Do ponto de vista de realização legal do injusto, autores dos dois tipos de ilícitos são considerados culpados, mas não possuem a mesma vulnerabilidade.

De tais considerações, vislumbra-se que a vulnerabilidade dos cidadãos em relação ao sistema se apresenta em graus diversos e recebe a influência tanto de fatores de ordem pessoal quanto social, ou seja, são os elementos encontrados no mundo fenomênico que definem o âmbito de autodeterminação do sujeito no momento em que este cometeu o

\footnotetext{
${ }^{404}$ Idem, p. 270.

${ }^{405}$ ZAFFARONI, Eugenio Raúl; SLOKAR, Alejandro; ALAGIA, Alejandro. Derecho Penal: parte general. 2. ed. Buenos Aires: Ediar, 2002. p. 654.

${ }^{406}$ WACQUANT, Loïc. Op.cit., p. 101-105.
} 
crime. Sob este fundamento, a culpabilidade por vulnerabilidade revela-se uma teoria voltada a conter a violência abusiva das sanções penais, uma vez que reduz o limite da clássica culpabilidade pelo injusto ou, no máximo, coincide com o este ${ }^{407}$.

Desta feita, a culpabilidade por vulnerabilidade torna-se uma das possíveis teses a serem encampadas no Brasil, onde se encontra gritante situação de desigualdade social, em busca de um sistema penal menos elitista e mais sensível à realidade humana, utilizando as variáveis de forma contrasseletiva, justificando uma incidência menor do poder repressivo sobre os menos inseridos socialmente e que, consequentemente, se tornam os mais visados pelo sistema; assim sendo, faz-se plausível buscar nesta nova culpabilidade uma forma de amenizar a seletividade do sistema punitivo pátrio, tanto porque, pelo reconhecimento da culpabilidade por vulnerabilidade pode-se dar contornos dogmáticos eficazes à redução de uma falha estrutural do sistema repressivo, tentando estabelecer padrões de aplicação da lei com a maior possibilidade de isonomia e ética ${ }^{408}$.

Em termos de aplicabilidade prática da teoria da culpabilidade por vulnerabilidade, Eugenio Raul Zaffaroni assegura a possibilidade de se reduzir a pena abaixo do mínimo legal a partir do momento que se a reconheça no caso concreto, isto porque a quantificação penal tem por limite máximo os parâmetros da culpabilidade de ato, entretanto, o reconhecimento da situação de vulnerabilidade da pessoa em relação ao exercício do poder punitivo permite estabelecer penas abaixo do limite legal prefixado, uma vez que este novo conceito se atém ao esforço do indivíduo para assumir a postura de vulnerável perante a agência judicial e, assim sendo, quanto maior o esforço pessoal, menor será o espaço do Estado para baixar a pena aquém do limite assinalado pela culpabilidade e vice-versa ${ }^{409}$.

Em outras palavras, para se lograr a quantificação penal, atenta-se à culpabilidade de ato que estabelece o limite máximo da reprovação que recairá sobre o indivíduo e se verifica o espaço de poder da agência judicial para quantificar a pena abaixo disso. O que determina a possibilidade de tanto é o esforço que a pessoa desempenhou para alcançar a situação de vulnerabilidade; sob este prisma, o esforço compõe a magnitude do conceito do injusto $^{410}$.

Configura-se regra geral que, quando o delinquente atinge a vulnerabilidade com pouco esforço, concede à agência judicial a possibilidade de lhe impor penas leves ou

\footnotetext{
${ }^{407}$ LEMOS, Clécio José Morandi de Assis. Culpabilidade por vulnerabilidade. In Boletim IBCCRIM. São Paulo : IBCCRIM, ano 17, n. 210, mai., 2010, p. 16-17.

408 Idem.

${ }^{409}$ ZAFFARONI, Eugenio Raul. Hacia un realismo marginal. Caracas: Monte Avila Latinoamericana, 1992, p.110.

${ }^{410}$ Idem.
} 
mínimas sem que haja questionamentos por parte de outros órgãos públicos, ao passo que, quando o delinquente atinge a vulnerabilidade mediante significativo esforço, autoriza que a agência judicial intensifique a reprimenda que recairá sobre ele ${ }^{411}$.

Tem-se então que, em uma perspectiva penal baseada no conceito agnóstico de pena, a pena concreta resulta da análise conjunta do juízo de reprovabilidade que se baseia no âmbito de autodeterminação da pessoa quando do cometimento do ilícito e do juízo de reprovação pelo esforço do agente para alcançar a situação de vulnerabilidade em que o sistema penal tem concretizado sua periculosidade. Isso faz com que o vazio ético que a culpabilidade pelo ato apresenta seja preenchido pelo conteúdo trazido pela definição de culpabilidade pela vulnerabilidade, que sintetiza a culpabilidade penal, indicadora final da quantia de poder punitivo suscetível de se habilitar ${ }^{412}$.

${ }^{411}$ Idem.

412 THOREL, Gianpaolo. Op.cit., p. 149. 


\section{CONCLUSÃO}

Analisou-se no presente trabalho o princípio da coculpabilidade que aborda a questão da corresponsabilização do Estado em relação à marginalização de determinados indivíduos, os quais vislumbram a prática criminosa como única opção restante para alcançar os objetivos de melhoria nas condições, após uma vida de exclusão.

Partiu-se a análise dos conceitos e princípios trazidos pela Magna Carta brasileira a fim de verificar a compatibilidade do tema com os preceitos do Estado Democrático de Direito e com os principais ditames contemplados na Lei Maior à qual todas as outras leis, decisões jurisprudenciais e teses doutrinárias devem obediência e que norteiam a incidência do Direito Penal.

Foram apontados ainda quais os deveres que a Constituição Federal, pela expressa previsão de direitos humanos em seu aspecto social e de relevância internacional, confere conjuntamente ao Estado e à sociedade no que tange à concreção do bem comum, à erradicação da pobreza e à minimização das desigualdades.

Entretanto, durante a pesquisa constatou-se que a atuação do Estado se dá de forma seletiva, tanto na concreção dos direitos sociais fundamentais, quanto ao executar seu poder punitivo, consolidando-se, assim, a estratificação social por meio da imposição de uma disciplina marginalizante sobre os corpos dominados.

O poder de punir do Estado é regulamentado pelos princípios constitucionais penais, os quais asseguram a dogmática constitucional que confere primazia à pessoa humana. Neste sentido também aparece o Direito Penal que, após a Reforma de 1984, calca-se na complexa noção de culpabilidade.

A culpabilidade, com a importância de princípio constitucional, aparece na dogmática penal como elemento do conceito analítico de crime e, na teoria da pena, como fundamento desta e ainda como limite de sua aplicação.

E é da culpabilidade que decorre a concepção abordada no presente trabalho acerca da coculpabilidade.

Definido seu conceito e sua importância, cogitou-se a maneira mais eficaz de positiva-lo no ordenamento jurídico brasileiro.

Reconhecendo-se o princípio da coculpabilidade a reprovação penal exercida pelo poder punitivo restará mitigada quando se estiver diante de um indivíduo que, embora tenha infringido uma norma, seu comportamento padeceu da autodeterminação necessária 
para se reprovar o fato, o que ocorre em decorrência da precariedade da assistência estatal que lhe foi ofertada.

A importância da positivação do princípio da coculpabilidade é nítida, uma vez que, tanto pela mentalidade dos operadores do Direito em que se vislumbra certo temor em conferir validade prática a um conceito que ainda não está escrito expressamente na lei penal, quanto pelo receio da repercussão que suas consequências jurídicas provocarão, ocorrerá verdadeira transformação na orientação político-criminal brasileira, principalmente no que diz respeito aos critérios de seletividade do Direito Penal e na afirmação do Direito Penal Mínimo.

Da pesquisa jurisprudencial realizada no presente estudo vislumbra-se que a questão divide entendimentos, provocando as mais variadas interpretações e diversos argumentos por parte dos julgadores, este se faz outro argumento no sentido de que é latente a necessidade de positivar o conceito, porque somente quando ele estiver escrito em lei é que terá a devida atenção por parte dos julgadores.

Há quem o reconheça como circunstância atenuante, outros propõem sua adoção como causa de diminuição de pena, outros vislumbram-no como supralegal de exculpação e outros ainda o negam veementemente por considera-lo proposta de impunidade.

A atual conjuntura impõe o reconhecimento e a inserção do princípio da coculpabilidade no ordenamento jurídico brasileiro; outros países de realidade social semelhantes à brasileira já quebraram o paradigma traçado pelos movimentos de lei e ordem nos quais, sinteticamente, com os rigores da pena se resolvem praticamente todos os problemas da criminalidade.

Desta feita, se, em cada caso específico, constatar-se que a autodeterminação do sujeito se encontrava reduzida, bem como se atestar a sua inferiorização em decorrência de condições sociais adversas, existirá um imperativo fático imposto pela sociedade organizada e pelo Estado e deverá ser reconhecido o estado de vulnerabilidade do sujeito, com a consequente redução ou, dependendo da circunstância, a exclusão de sua responsabilidade penal.

Isso evidencia que o princípio da coculpabilidade se faz o elemento jurídico apto a proteger o valor supremo da dignidade da pessoa humana em face da restrição do espaço social em que a camada menos favorecida da sociedade se situa.

Pelo conceito de coculpabilidade e ante a análise interdisciplinar que este princípio exige para a devida compreensão de sua amplitude, deparou-se com a questão incisiva da seletividade do sistema penal que clama por uma solução urgente. 
Cogitou-se, então, um aperfeiçoamento do conceito inicial de coculpabilidade, o qual provocou uma análise inclusive sobre a culpabilidade, elemento que é a base de toda a teoria do delito na sistemática penal atual, e que, ao ver dos estudiosos, também necessita de uma evolução em termos de acepção.

A proposta foi no sentido de, quando se analisar a culpabilidade, direcionar nesse contexto a atenção para a vulnerabilidade do autor do fato em relação ao sistema, se seria ele um dos indivíduos previamente taxados pelo próprio Estado como pretenso futuro criminoso.

Evidentemente a situação de vulnerabilidade varia de pessoa para pessoa, o que obrigaria o juiz a realizar uma análise específica em cada caso.

A noção da culpabilidade por vulnerabilidade acaba com o dilema de se fixar ou não a pena abaixo do mínimo legal nas fases iniciais da dosimetria, porque implica na redução da própria culpabilidade enquanto elemento constitutivo do crime.

Deve-se reconhecer, então, que o conceito de coculpabilidade serviu de base para a formulação de um conceito novo, que se faz necessário e que dará o passo mais firme rumo ao Direito Penal Mínimo e ao fim da seletividade do sistema, cumprindo a Constituição Federal de acordo com a realidade fática que é imposta, afinal, já que o Direito não possui aptidão para reduzir as desigualdades sociais e regionais, o Direito Penal encontrou na inserção do conceito de vulnerabilidade dentro do instituto da culpabilidade uma forma de minimizar as desigualdades fomentadas pela sua própria sistemática. 


\section{REFERÊNCIAS BIBLIOGRÁFICAS}

ABRAMOVICH, Victor; COURTIS, Christian. Los derechos sociales como derechos exigibles. $2^{\mathrm{a}}$ ed. Madrid: Editorial Trotta, 2004.

ALEXY, Robert. Teoria de Los Derechos Fundamentales. Trad. Ernesto Garzón Vladés. Madri: Centro de Estúdios Políticos y Constitucionales, 2001.

ALEXY, Robert. Teoria de la argumentación jurídica. La teoria del discurso racional como teoria de la fundamentación jurídica. Traducción de Manuel Atienza e Isabel Espejo. Madrid: Centro de Estudios Constitucionales, 1989.

ANDRADE, Vera Regina Pereira de. Sistema Penal Máximo X Cidadania Mínima: Códigos da violência na era da globalização. Porto Alegre: Livraria do Advogado, 2003.

ANDREUCCI, Ricardo Antunes. Dimensão humana e direito penal. José Bushatsky Editor, Revista Ciência Penal, Vol. 2, 1974.

ÁVILA, Humberto. Teoria dos princípios: da definição à aplicação dos princípios jurídicos. São Paulo: Malheiros Editores, 2007.

AZUMA, Felipe Cazuo. Inexigibilidade de Conduta conforme a Norma. Curitiba: Juruá, 2007.

BACIGALUPO ZAPATER, Enrique. Derecho Penal Material y Estado Democrático de Derecho. Justicia Penal y Derechos Fundamentales, Madrid/Barcelona: Ed. Marcial Pons, 2002.

BARATTA, Alessandro. Criminologia crítica e crítica do direito penal. 3. ed. Tradução de Juarez Cirino dos Santos. Rio de Janeiro: Revan: Instituto Carioca de Criminologia, 2002.

BARATTA, Alessandro. Viejas y nuevas estratégias en la legitimación del derecho penal. Poder y Control, Barcelona, 1986.

BARATTA, Alessandro. Integración-prevención: uma nueva fundamentacion de la pena dentro de la teoria sistêmica. Doctrina Penal - teoría y pratica en las ciencias penales, Buenos Aires: De Palma, n. 29 a 32, 1985.

BARROS, Sérgio Resende de. Direitos humanos: paradoxo da civilização. Belo Horizonte: Del Rey, 2003.

BASILEU GARCIA. Instituições de direito penal. São Paulo: Max Limonad, 1970.

BASTOS, Celso Ribeiro. Curso de Direito Constitucional. São Paulo: Saraiva, 1978.

BATISTA, Nilo. Introdução Crítica ao Direito Penal Brasileiro, 9 ${ }^{\mathrm{a}}$ ed. Rio de Janeiro: Editora Revan, 2004. 
BAUMANN, Jürgen. Culpabilidad y Expiación. Nuevo Pensamiente Penal. Revista Cuatrimestral de Derecho Y Ciencias Penales. Fundada por Luis Jiménez de Asúa. Año 1, n ${ }^{\circ}$, Enero-abril 1972.

BAUMAN, Zygmunt. O mal-estar da pós-modernidade. Rio de Janeiro: Jorge Zahar, 1998.

BAUMAN, Zygmunt. Globalização: As conseqüências humanas. Rio de Janeiro: Jorge Zahar, 1999.

BECCARIA, Cesare Bonesana. Dos delitos e das penas. São Paulo: Editora Martin Claret, 2002.

BECKER, Howard S. Outsiders. New York: Free Press, 1.963.

BETTIOL, Giuseppe. Direito Penal. São Paulo: Revista dos Tribunais, 1971.

BITENCOURT, Cezar Roberto. Tratado de Direito Penal. Parte Geral. Vol.I, 8.ed. São Paulo: Saraiva, 2003.

BOBBIO, Norberto. A era dos direitos. Rio de Janeiro: Editora Campos, 1992.

BOBBIO, Norberto. Igualdade e liberdade. 4. ed. Rio de Janeiro: Ediouro, 2000.

BOBBIO, Norberto. Sociedade e estado na filosofia política moderna. Trad. Carlos Nelson Coutinho. $4^{\mathrm{a}}$ ed. São Paulo: Ed. Brasiliense, 1994.

BONAVIDES, Paulo. Curso de direito constitucional. 21. ed. São Paulo: Malheiros, 2007.

BOSCHI, José Antonio Paganella. Das penas e seus critérios de aplicação. 4 ed. Porto Alegre: Livraria do Advogado, 2006.

BRANDÃO, Cláudio. Culpabilidade: sua análise na dogmática e no direito penal brasileiro. Revista da associação brasileira de professores de ciências penais. São Paulo: Revista dos Tribunais, v. 1, ano 1, p.171-184, jul./dez. 2004.

BRANDÃO, Claudio. Curso de Direito Penal. Rio de Janeiro: Forense, 2008.

BRASIL. CONSTITUIÇÃO DA REPÚBLICA FEDERATIVA DO BRASIL. Brasília: Senado, 1988.

BRODT, Luís Augusto Sanzo. Da consciência da ilicitude no Direito Penal brasileiro. Belo Horizonte: Del Rey, 1996.

BRUNONI, Nivaldo. Princípio da culpabilidade: considerações, fundamento, teoria e consequências. Curitiba: Juruá, 2008.

BULOS, Uadi Lammego. Constituição Federal anotada. São Paulo: Saraiva, 2002. 
CAENEGEM, R. C. van. Uma introdução histórica ao direito privado. São Paulo: Martins Fontes, 1999.

CAMARGO, Antônio Luís Chaves de. Bases do Direito Penal no Estado Democrático de Direito. Revista Impulso da Universidade Metodista de Piracicaba.

CANARIS, Claus-Wilhelm. Pensamento sistemático e conceito de sistema na ciência do direito. Trad. António Menezes Cordeiro. Lisboa: Fundação Calouste Gulbenkian, 1996.

CANOTILHO, José Joaquim Gomes. Direito Constitucional e Teoria da Constituição. 6 ed. Coimbra/Portugal: Livraria Almedina, 2002.

CAPEZ, Fernando. Curso de Direito Penal. Vol.1. 7. ed. São Paulo: Saraiva, 2004.

CAPRA, Fritjof. O ponto de mutação. São Paulo: Cultrix, 2006.

CÁRCOVA, Carlos María. La opacidad del derecho Madrid: Trotta, 1998.

CARVALHO, Marcia Dometila Lima de. Fundamentação constitucional do direito penal. Porto Alegre: Sergio Antonio Fabris, 1992.

CARVAlHO, Amilton Bueno de; CARVALHO, Salo de. Aplicação da pena e garantismo. 4. ed. Rio de Janeiro: Lumen Juris, 2008.

CARVALHO, Salo de. Pena e Garantias: uma leitura do garantismo de Luigi Ferrajoli no Brasil. Rio de Janeiro: Lumen Juris, 2001.

CARVALHO, Salo de. A co-responsabilidade do Estado nos crimes econômicos: fundamentos doutrinários e aplicabilidade judicial. Porto Alegre: Livraria do Advogado, 2008 .

CASTRO, Renato de Lima. Garantismo penal: uma ilusão? In: PRADO, Luiz Regis. (Org.). Direito penal contemporâneo: Estudos em homenagem ao Professor José Cerezo Mir. São Paulo: Revista dos Tribunais, 2007.

CEREZO MIR, José. El concepto material de culpabilidad. Criminalia. Academia Mexicana de Ciencias Penales, Año LXIII, n. 2. México, D.F: Mayo-Ago, 1997.

CHAUI, Marilena. Convite à Filosofia. Editora Ática: São Paulo, 2002.

COHEN, Albert K. Delinquent boys: the culture of the gang. Londres: Routledge \& Kegan Paul, 1956.

CONDE, Francisco Muñoz. Introducción al derecho penal. 2.ed. Aboso. Montevideo - Buenos Aires, 2003.

CONDE, Francisco Munõz. Teoria geral do delito. Tradução de Juarez Tavares e Luiz Regis Prado. Porto Alegre: Sergio Antonio Fabris, 1988. 
CONDE, Francisco Muñoz; HASSEMER, Winfried. Introdução à Criminologia. Tradução: Cíntia Toledo Miranda Chaves. Rio de Janeiro: Lúmen Juris, 2008.

CONVENÇÃO AMERICANA DE DIREITOS HUMANOS. Costa Rica, 1969.

COQUARD, Oliver. Marat. Tradução: C. H. Silva. São Paulo: Scritta, 1996.

COSTA, Helena Regina Lobo da. A dignidade humana: teorias de prevenção geral positiva. São Paulo: Revista dosTribunais, 2008.

COSTA, Pedro Jorge. Relações entre pena concreta e culpabilidade no direito brasileiro. Revista Forense, vol. 410, jul-ago 2010.

DALLARI, Dalmo de Abreu. Elementos de Teoria Geral do Estado. 22.ed.atual. São Paulo: Saraiva, 2001.

DE GREEFF, Étienne. Introduction à la criminology. Vol.1. Paris: PUF, 1948.

DOTTI, Rene Ariel. Curso de direito penal: parte geral. 2. ed., rev. atual. e ampl. Rio de Janeiro: Forense, 2005.

ESPINDOLA, Ângela Araujo da Silveira. A Crise Conceitual e a (re)construção interrompida da Soberania: o fim do Estado-Nação? In: MORAIS, José Luis Bolzan de (Org.). O Estado e suas crises. São Paulo: Companhia das Letras, 2005.

FERRAJOLI, Luigi. Derecho y razión: teoría del garantismo penal. Editorial Trotta, 1995.

FERRAJOLI, Luigi. Derechos y garantias - la ley del más de débil. Trad. Perfecto Andrés Ibañez. Madrid: Editorial Trotta, 1999.

FERRAJOLI. Luigi. Direito e razão: teoria do garantismo penal. Tradução de Ana Paula Zomer et.al. São Paulo: Editora Revista dos Tribunais, 2002.

FERREIRA. Luís Pinto. Princípios Gerais do Direito Constitucional Moderno. São Paulo: Saraiva. 1983.

FERRI, Enrico. Princípios de Direito Criminal: o criminoso e o crime. 2.ed. Campinas: Bookseller, 2003.

FIRMO, Aníbal Bruno de Oliveira. Direito penal, parte geral, tomo II: fato punível. Rio de Janeiro: Forense, 2003.

FONSECA, Antonio Cezar Lima da. Direito Penal do Consumidor. Porto Alegre: Livraria do Advogado, 1996.

FOUCAULT, Michel. Microfísica do poder. 15. ed. Rio de Janeiro: Graal, 2000.

FOUCAULT, Michel. Vigiar e punir: nascimento da prisão. Trad. Raquel Ramalhete. 34 ed. Petrópolis, Vozes, 2007. 
FRANCO, Alberto Silva. Código Penal e sua Interpretação Jurisprudencial. 5.ed. São Paulo: Revista dos Tribunais, 1995.

FRAGOSO, Heleno Cláudio. Lições de direito penal: parte geral. 15. ed. rev. e atual. Rio de Janeiro: Forense, 1994.

FRAGOSO, Heleno Cláudio. O Direito Penal comparado na América Latina. Revista de Direito Penal, n. 24, Rio de Janeiro, 1979.

FRAGOSO, Heleno Cláudio. Lições de Direito Penal. 16.ed. Rio de Janeiro: Forense, 2003.

GOFFMAN, Erving. A representação do eu na vida cotidiana. Petrópolis: Vozes, 1999.

GOMES, Mariângela Gama de Magalhães. O princípio da proporcionalidade no direito penal. São Paulo. Editora Revista dos Tribunais: 2003.

GRECO, Rogério. Curso de Direito Penal - Parte Geral. Rio de Janeiro: Impetus, 2009.

GROSSI, Paolo. Mitologias jurídicas da modernidade. Florianópolis: Fundação Boiteux, 2004.

GUIMARÃES, Claudio Alberto Gabriel. Funções da pena privativa de liberdade no sistema penal capitalista. Rio de Janeiro: Revan, 2007.

GUIMARÃES, Cláudio Alberto Gabriel. A culpabilidade compartilhada como princípio mitigador da ausência de efetivação dos direitos humanos fundamentais. In: Novos Estudos Jurídicos, vol.3, n. 14, 2009.

GÜNTHER, Klaus. A culpabilidade no Direito Penal atual e no futuro.Tradução de Juarez Tavares. Doutrina Internacional. Revista Brasileira de Ciências Criminais, ano 6, n. 24. São Paulo: Editora Revista dos Tribunais, outubro-dezembro 1998.

HASSEMER, Winfried. Introdução aos fundamentos do direito penal. Porto Alegre: Safe, 2005.

HENKEL, Heinrich. Exigibilidad e Inexigibilidad Como Princípio Jurídico Regulativo. Buenos Aires: Editorial B de F, 2005.

HESPANHA, António Manuel. Cultura jurídica européia: síntese de um milênio. Florianópolis: Fundação Boiteux, 2005.

JAKOBS, Günther. Conocimiento y desconocimiento de la norma. Problemas capitales del derecho penal moderno. Buenos Aires: Hammurabi, 1998. 
JESCHECH, Hans Heinrich. El Principio de Culpabilidad Como Fundamento Y Límite De La Punibilidade En El Derecho Alemán Y Español. San Sebastián: Eguzkilore Cuaderno del Instituto Vasco de Criminología, no 9, 1995.

JESCHECK, Hans-Heinrich; WEIGEND, Thomas. Tratado de derecho penal: parte general. Traducción de Miguel Olmedo Cardenete. 5. ed. Granada: Comares, 2002.

JUNQUEIRA, Gustavo Octaviano Diniz. Finalidades da Pena. Editora Manole.

LEMOS, Clécio José Morandi de Assis. Culpabilidade por vulnerabilidade. In Boletim IBCCRIM. São Paulo : IBCCRIM, ano 17, n. 210, mai., 2010.

LOBATO, José Danilo Tavares. Da evolução dogmática da culpabilidade. In: GRECO, Luís; LOBATO, Danilo (org.). Temas de direito penal - parte geral. Rio de Janeiro: Renovar, 2008.

LOPES, Luciano Santos. Os elementos normativos do tipo penal e o princípio constitucional da legalidade. Porto Alegre: Sergio Antonio Fabris Editor, 2006.

LOPES, Mauricio Antônio Ribeiro. Princípio da insignificância no direito penal: análise à luz das leis 9.009/95 (juizados especiais criminais), 9.503/97 (código de trânsito brasileiro) e da jurisprudência atual. 2. ed., rev. atual. e ampl., São Paulo: Revista dos Tribunais, 2000.

LUISI, Luiz. Os princípios constitucionais penais. 2. ed. Porto Alegre: Sergio Antonio Fabris, 2002.

MANNHEIM, Hermann. Criminologia. Vol.II. Lisboa: Fundação Calouste Gulbenkian, 1985.

MARAT, Jean-Paul. Plano de legislação criminal. Tradução: João Ibaixe Jr. e Carmensita Ibaixe - São Paulo: Quartier Latin, 2008.

MARMELSTEIN, George. Curso de direitos fundamentais. São Paulo: Atlas, 2008.

MARQUES, José Frederico. Tratado de direito penal, v. III. Campinas: Editora Millennium, 2002.

MEIRELES, Ana Cristina Costa. A eficácia dos direitos sociais. Salvador: JusPodivm, 2008.

MERTON, Robert K. Sociologia: teoria e estrutura. São Paulo: Mestre Jou, 1970.

MIR PUIG, Santiago. Derecho penal - parte general. 5ª edición. Barcelona: 1998.

MIRANDA, Jorge. Manual de direito constitucional. Tomo IV. Coimbra: Coimbra, 1991.

MOLINA, Antonio García-Pablos de. Criminología: Una Introducción a sus fundamentos teóricos para Juristas. Valencia: Tirant lo Blanch, 1.996. 
MOLINA, Antonio Garcia Pablos; GOMES, Luiz Flavio. Criminologia. 4.ed. São Paulo: Editora Revista dos Tribunais, 2002.

MORAES, Alexandre de. Direito Constitucional. 12.ed. São Paulo: Atlas, 2002.

MOURA, Grégore Moreira de. Do princípio da co-culpabilidade no direito penal. Rio de Janeiro: Impetus, 2006.

NEPOMOCENO, Alessandro. Além da Lei. A face obscura da sentença penal. Rio de Janeiro: Revan, 2004.

NORONHA, E. de Magalhães. Direito penal. 30 ed. São Paulo: Saraiva, 1995.

NUCCI, Guilherme de Souza. Código Penal comentado. 4. ed. rev., atual. e ampl. São Paulo: Revista dos Tribunais, 2003.

NUCCI, Guilherme de Souza. Individualização da pena. 3 ed. ver. atual e ampl. São Paulo: Revista dos Tribunais, 2009.

NUNES, Luiz Antonio Rizzatto. O princípio Constitucional da Dignidade da Pessoa Humana. São Paulo: Saraiva, 2002.

OLIVEIRA FILHO, Mário de. Temas Atuais de Advocacia Criminal. São Paulo: Etna, 1996.

PALAZZO, Francesco C. Valores constitucionais e direito penal - um estudo comparado. Trad. Gérson Pereira dos Santos. Porto Alegre: Sérgio Antonio Fabris Editor, 1989.

PAULO, Vicente; ALEXANDRINO, Marcelo. Direitos fundamentais. Rio de janeiro: Impetus, 2003.

PAVARINI, Massimo. Control y dominación. Teorias criminológicas burguesas y proyecto hegemónico. Tradução de Ignacio Munagorri. México: Siglo Veintiuno, 1988.

PEPE, Albano Marcos Bastos. Kant e a modernidade jurídica: razão e liberdade. In: COPETTI, André; STRECK, Lenio Luiz; ROCHA, Leonel Severo (Org.). Constituição, sistemas sociais e hermenêutica. Porto Alegre: Advogado, 2006.

PRADO, Luiz Regis. Bem jurídico penal e Constituição. 4.ed.rev., atual. e ampl. São Paulo: Editora Revista dos Tribunais, 2009.

PRADO, Luiz Regis. Curso de direito penal brasileiro - Parte geral. Vol. 1. 3.ed., São Paulo: Revista dos Tribunais, 2002.

QUEIROZ, Paulo. Funções do direito penal: legitimação versus deslegitimação do sistema penal. 2. ed. rev., atual e ampl. São Paulo: Editora Revista dos Tribunais, 2005.

QUINNEY, Richard. O controle do crime na sociedade capitalista: uma filosofia crítica da ordem legal. Criminologia crítica. Rio de Janeiro: Graal, 1980. 
RAWS, John. Teoría de la justicia. Tradução: Maria Dolores González. México: Fondo de Cultura Economica, 1993.

REALE JÚNIOR, Miguel. Instituições de direito penal. 3. ed. Rio de Janeiro: Forense, 2009.

REALE JÚNIOR, Miguel. Teoria do Delito. São Paulo: Editora Revista dos Tribunais, 1998.

RIVEROS, Jaime Náquira. Imputabilidad, conciencia de lo injusto y contexto situacional normal: De sú objeto, contenido e relación. Doctrina Penal - Teoría y Práctica em las Ciencias Penales, año 12, nº 45 a 48. Buenos Aires: Ediciones Delpalma, 1989.

ROCHA, Fernando A. N. Galvão da. Direito penal - parte geral. Rio de Janeiro: Impetus, 2004.

RODRÍGUEZ, Laura Zúñiga. Política criminal. Madrid: Colex, 2001.

ROXIN, Claus. Derecho penal. Madrid: Civitas, 1997.

ROXIN, Claus. Estudos de Direito Penal. Tradução Luís Greco. 2.ed. Rio de Janeiro: Renovar, 2008.

ROXIN, Claus. A culpabilidade e sua Exclusão no Direito Penal. In: Revista Brasileira de Ciências Criminais. São Paulo: Revista dos Tribunais, 2004.

RUSCHE, George; KIRCHHEIMER, Otto. Punição e estrutura social. 2.ed. Rio de Janeiro: Revan, 2004.

SANTORO FILHO, Antonio Carlos. Teoria do tipo penal. São Paulo: Editora de Direito, 2001.

SANTOS, Juarez Cirino dos. Direito Penal: a nova parte geral. Rio de Janeiro, Forense, 1985.

SANTOS, Juarez Cirino dos. A moderna teoria do fato punível. Curitiba: Lumen Juris, 2005.

SANTOS, Juarez Cirino dos. Teoria do Crime. São Paulo: Acadêmica, 1994.

SANTOS, Sérgio Roberto Leal dos. Manual de Teoria da Constituição. São Paulo: Revista dos Tribunais, 2008.

SARLET, Ingo Wolfgang. A eficácia dos direitos fundamentais. 6. ed. Porto Alegre: Livraria dos Advogados, 2006.

SARLET, Ingo Wolfgang. Dignidade e direitos fundamentais na Constituição Federal de 1988. Porto Alegre: Livraria do Advogado, 2001. 
SARMENTO, Daniel. A ponderação de interesses na Constituição. Rio de Janeiro: Lúmen Júris, 2000.

SHECAIRA, Sérgio Salomão. Criminologia. 2.ed.rev.,atual.,ampl. Editora Revista dos Tribunais, 2008.

SIDMAN, Murray. Coerção e suas implicações. Editora Livro Pleno, 2009.

SILVA, José Afonso da. Curso de Direito Constitucional Positivo. 22.ed.rev.atual. São Paulo: Malheiros Editores, 2003.

SKINNER, Burrhus Frederic. Ciência e comportamento humano. Editora Martins Fontes, 2007.

SOBRINHO, José Wilson Ferreira. Repertório IOB de Jurisprudência. São Paulo: 23/1995.

SOUZA, Daniel Coelho de. Interpretação e democracia. 2ed. São Paulo: Editora Revista dos Tribunais, 1979.

STARCK, Christian. El concepto de ley em la constituición alemana. Madrid, Centro de Estudios Constitucionales, 1979.

STRECK, Lenio. O trabalho dos juristas na perspectiva do Estado Democrático de Direito: da utilidade de uma crítica garantista. Rio de Janeiro, 1996.

STRECK, Lenio Luiz; MORAIS, José Luis Bolzan de. Ciência política e teoria do Estado. 5. ed. rev. e atual. Porto Alegre: Livraria do Advogado, 2006.

STUMM, Raquel Denise. Princípio da Proporcionalidade no Direito Constitucional Brasileiro. Porto Alegre, Livraria do Advogado Editora, 1995.

SUTHERLAND, Edwin. H. Princípios de criminologia. Tradução Asdrúbal M. Gonçalves. São Paulo: Livraria Martins, 1949.

TARDE, Gabriel. As multidões e as seitas criminosas. In: A opinião e as massas. Tradução de Eduardo Brandão. 2.ed. São Paulo: Martins Fontes, 2005.

TARDE, Gabriel. Les loies de l'imitation. 6.ed. Paris: Alcan, 1911.

TAVARES, Juarez. Culpabilidade: A Incongruência dos Métodos. Revista Brasileira de Ciências Criminais, ano 6, $\mathrm{n}^{\mathrm{o}}$ 24. São Paulo: Editora Revista dos Tribunais, out-dez 1998.

TAVARES, Juarez. Teorias do delito (variações e tendências). São Paulo: Revista dos Tribunais, 1980.

TELES, Ney Moura. Direito Penal: parte geral. São Paulo: Editora de Direito, 1996. 
THOREL, Gianpaolo. Contributo ad una etica della colpevolezza. In: Studi sulla colpevolezza, a cura di L. Mazza. Torino, 1990.

TOLEDO, Francisco de Assis. Princípios básicos de Direito Penal. 5.ed. São Paulo: Saraiva, 1994.

TORRE, Ignácio Berdugo Gómez de la. Lecciones de derecho penal. Parte general. 2.ed.Editorial: WK Educación, 1999.

VILA NOVA, Sebastião. Introdução à sociologia. 4.ed.rev.e aum. São Paulo: Atlas, 1999.

WACQUANT, Loïc. As Prisões da Miséria. Rio de Janeiro: Jorge Zahar Editor, 2001.

WELZEL, Hans. Direito Penal. Tradução de Afonso Celso Rezende. Campinas: Romana, 2004.

WELZEL, Hans. O novo sistema jurídico-penal: uma introdução à doutrina da ação finalista. Tradução de Luiz Regis Prado. 2. ed. São Paulo: Revista dos Tribunais, 2009.

WIEACKER, Franz. História do Direito Privado Moderno. Lisboa: Fundação Calouste Gulbenkian, 2004.

YAROCHEWSKY, Leonardo Isaac. Da Exigibilidade de Conduta Diversa. Belo Horizonte: Del Rey, 2000.

ZAFFARONI, Eugenio Raúl; ALAGIA, Alejandro; SLOKAR, Alejandro. Derecho penal: parte general. 2. ed. Buenos Aires: Ediar, 2002.

ZAFFARONI, Eugenio Raúl e PIERANGELI, José Henrique. Manual de direito penal brasileiro. 7.ed. rev. e atual. São Paulo: Revista dos Tribunais, 2008.

ZAFFARONI, Eugenio Raul. Em busca das penas perdidas: a perda da legitimidade do sistema penal. Tradução: Vânia Romano Pedrosa e Amir Lopes Conceição. Rio de Janeiro: Revan, 2001.

ZAFFARONI, Eugenio Raul. Teoria del delito. Buenos Aires: Editar, 1973. 